\title{
1 Fusobacterium nucleatum host cell binding and invasion induces IL-8 and CXCL1 secretion that drives colorectal cancer cell migration
}

\author{
Michael A. Casasanta ${ }^{1, \&}$, Christopher C. Yoo ${ }^{1, \&}$, Barath Udayasuryan ${ }^{2,8}$, Blake E. Sanders ${ }^{1}$, Ariana \\ Umaña ${ }^{1}$, Yao Zhang ${ }^{3}$, Huaiyao Peng ${ }^{2}$, Alison J. Duncan ${ }^{1}$, Yueying Wang ${ }^{1}$, Liwu Li ${ }^{3}$, Scott S. Verbridge ${ }^{2}$, \\ Daniel J. Slade ${ }^{1, \#}$ \\ ${ }^{1}$ Virginia Polytechnic Institute and State University, Department of Biochemistry, Blacksburg, VA, USA. \\ 2 Laboratory of Integrative Tumor Ecology, and Virginia Tech - Wake Forest School of Biomedical Engineering and Sciences, \\ Blacksburg, VA, USA \\ 3 Virginia Polytechnic Institute and State University, Department of Biological Sciences, Blacksburg, VA, USA. \\ \& These authors contributed equally. \\ \# To whom correspondence should be addressed: Dr. Daniel J. Slade, Department of Biochemistry, Virginia Polytechnic Institute and \\ State University, Blacksburg, VA 24061. Telephone: +1 (540) 231-2842. Email: dslade@vt.edu
}

KEYWORDS: Fusobacterium nucleatum, Fap2, FadA, autotransporter, Type V secretion, colorectal cancer, host-pathogen, neutrophil, macrophage, inflammation, CRC, IL-8, CXCL1, CCL3, CXCL2, metastasis, tumor microenvironment, cytokine

Fusobacterium nucleatum is implicated in the acceleration of colorectal cancer (CRC), yet the mechanisms by which this bacterium modulates the tumor microenvironment remain understudied. Here we show that binding and cellular invasion of $\mathrm{CRC}$ cells selectively induces the secretion of the pro-inflammatory and metastatic cytokines IL-8 and CXCL1, which we then show induces robust migration of HCT116 cancer cells. Next, we demonstrate that cytokine signaling by cancer cells is largely driven by invasion coordinated by the surface adhesin Fap2. By contrast, we show that F. nucleatum induced secretion of CCL3, CXCL2, and TNFa cytokines from neutrophils and macrophages is Fap2 independent. Finally, we show that inhibiting $F$. nucleatum host-cell binding and entry using galactose sugars, neutralizing membrane antibodies, and deletion of the fap2 gene, lead to attenuated cytokine secretion and cellular migration. As elevated IL-8 and CXCL1 levels in cancer have been associated with increased metastatic potential and cell seeding, poor prognosis, and enhanced recruitment of tumor-associated macrophages and fibroblasts within tumor microenvironments, these data show that $F$. nucleatum directly and indirectly modulates immune and cancer cell signaling and migration. In conclusion, as viable F. nucleatum were previously shown to migrate within metastatic CRC cells, we propose that inhibition of host cell binding and invasion, potentially through vaccination or novel galactoside compounds, could be an effective strategy for reducing $F$. nucleatum-induced signaling that drives metastasis and cancer cell seeding.

\section{INTRODUCTION}

The role of bacteria and viruses in the onset and progression of diverse cancers is well established (1-3). Recent studies on the oral, anaerobic, gram-negative bacterium Fusobacterium nucleatum in the acceleration of CRC pathogenesis have revealed as many questions as they have answered for the mechanisms and proteins this bacterium uses to potentiate disease (4-9). An overarching question in the field is: How does $F$. nucleatum enter and reside in tumors after likely arriving via the bloodstream from its native oral cavity? In addition, a second theme of pathogenesis that remains understudied is: Are these bacteria capable of leaving the primary tumor on or within immune or cancerous cells to seed and accelerate metastatic cancer sites (10)? Answering these questions will be key in understanding both the host and bacterial mechanisms at play in 
microbe-accelerated cancers. Two recent studies reported that $F$. nucleatum directly induces cancer cell metastasis through NF-KB increased expression of Keratin 7 (KRT7) (11), as well as increased expression of caspase activation and recruitment domain 3 (CARD3), and downregulation of E-cadherin (12). Herein we add to the mechanisms used by $F$. nucleatum to induce cellular migration. We show that direct binding and invasion of host cancer and immune cells by $F$. nucleatum induces the secretion of the proinflammatory and prometastatic cytokines IL-8 and CXCL1, and that conditioned media from F. nucleatum infected HCT116 CRC cells causes non-Fusobacterium exposed cells to migrate towards this cytokine rich media.

Chemokines/cytokines play a crucial role in tumor initiation, progression, and metastasis (13). Initially discovered as chemotactic mediators of leukocytes, they are now known to be secreted by several cell types and can be expressed constitutively or induced by inflammatory stimuli, including bacterial infections, and function in a variety of roles including cell survival, proliferation, angiogenesis, and cell migration. In cancer, chemokines mainly function in regulating angiogenesis, activating tumor-specific immune responses, and directly stimulating the tumor through autocrine or paracrine mechanisms (13).

The cytokines IL-8 (CXCL8) and CXCL1 (GROa) are well known to play a pivotal role in CRC progression. Multiple studies have indicated their important role in influencing CRC invasiveness. Elevated CXCL1 is correlated with cancer progression and metastasis and ultimately poor prognosis in patients with CRC; thus indicating its possible role as a biomarker for CRC (14). CXCL1 is an autocrine growth factor that binds to the receptor CXCR2 with high affinity. Many colorectal adenocarcinoma cell lines (LS174T, KM12L4, KM12C, SW480, HT29, and Caco2) constitutively express CXCL1, and it is well known that high levels of this cytokine increase invasive potential (15). Additionally, anti-CXCL1 or anti-CXCR2 antibodies have been shown to inhibit colon cancer cell proliferation (16). It is relevant for these studies that non-metastatic Caco2 and low-metastatic HT29 cell lines expressed lower levels of CXCL1 than the highly metastatic cancer cell line LS147T. In another study, Ogata et al. showed that CXCL1 increases the number of invasive DLD-1 and LoVo cells, and that these effects are quenched in the presence of anti-CXCL1 antibody (17). Furthermore, there is emerging evidence to indicate that CXCL1 participates in premetastatic niche formation in liver tissue which in turn recruits CXCR2-positive myeloid-derived suppressor cells (MDSC) to support liver metastases of CRC (18).

IL-8 is a ubiquitously prevalent cytokine in CRC where it has been characterized as the most potent neutrophil chemoattractant and activator in both in vivo and in vitro studies. Rubie et al. has shown that both IL-8 mRNA and protein expression were significantly upregulated in pathological colorectal tissues as well as enhanced in colorectal liver metastasis (19). Chen et al. showed that IL-8 and its receptor CXCR2 were highly upregulated in colon cancer (20). Additionally, Lee et al. showed that elevated levels of IL-8 in the serum and tumor microenvironment had enhanced the growth of human and mouse colon cancer cells while promoting the extravasation of cancer cells to lung and liver (21). IL-8 can bind to both CXCR1 and CXCR2, but it exerts different effects upon binding to either receptor (22). Binding to CXCR1 induces neutrophil migration, whereas binding to CXCR2 modulates angiogenic activity (13). The angiogenic effect of IL-8 promotes tumor growth by providing access to oxygen and nutrients, as well as an opportunity to metastasize.

Our initial goal was to investigate the role of outer membrane adhesins in F. nucleatum direct binding and invasion of cancer cells to determine if this was critical for altered cell signaling. Multiple adhesins have been characterized in $F$. nucleatum binding and signaling, with important roles for the small multimeric adhesin FadA in E-cadherin interactions and Wnt signaling that drives cellular proliferation $(6,23)$. Additional experiments uncovered the critical role of the large, outer membrane adhesin Fap2, a member of the Type $5 a$ autotransporter protein family (23-25). This protein docks with host cells through Gal/GalNAc sugar residues overexpressed on CRC cells, as well as protein-protein interactions with TIGIT on natural killer cells (26). However, aside from these two adhesins, most outer membrane proteins of $F$. nucleatum have not been characterized in cancer cell interactions. We have expanded upon these analyses by developing a new, modified version of a galactose kinase markerless gene deletion system capable of creating strains with unlimited gene deletions. We implemented this system to functionally characterize the role of the Type $5 a$ autotransporter adhesin Fap2, multiple uncharacterized Type 5c trimeric autotransporter adhesins (CbpF, $\mathrm{FvcB}, \mathrm{FvcC}, \mathrm{FvcD})(27,28)$, and the small, non-autotransporter multimeric adhesin FadA. Our studies reveal that binding and invasion of HCT116 CRC cells by F. nucleatum, which can be inhibited by small molecules, antibodies, or adhesin gene deletions, is critical to induce pro-inflammatory signaling cascades as well as cellular migration. 
Through the results presented here we propose that $F$. nucleatum modulates the tumor microenvironment through interactions with both $\mathrm{CRC}$ and immune cells, thereby leading to the secretion of cytokines that have been well characterized for their pro-oncogenic, metastatic, and immune cell recruitment functions. Our results show how a bacterium may accelerate but not initiate cancer, and how these cytokines could allow long-term, low bacterial load infections within tumors to propagate autocrine and paracrine signaling, leading to F. nucleatum-loaded cancer cells that initiate cellular seeding at distant sites including the liver.

\section{RESULTS}

\section{F. nucleatum 23726 outer membrane adhesins are critical for the binding and invasion of HCT116 CRC cells.}

Previous studies have established that $F$. nucleatum is highly invasive and can undergo a non-obligate intracellular life stage within epithelial, endothelial, keratinocytes, and potentially immune cells (29-32). We confirm the invasive potential of $F$. nucleatum subsp. nucleatum ATCC 23726 into HCT116 CRC cells using fluorescence microscopy (Fig 1A-C), imaging flow cytometry (Fig. 1D), and classic flow cytometry (Fig 1E) to validate our forthcoming experiments evaluating specific proteins in this invasion process.

To gain a deeper understanding of how F. nucleatum is contributing to the acceleration of cancer, we set out to understand the importance of verified cancer cell interactions, which are driven by surface exposed outer membrane adhesins. Our goal was to confirm the roles of FadA and Fap2 in HCT116 binding and signaling, as well as perform the first characterization of multiple Type $5 \mathrm{c}$ trimeric autotransporter adhesins which have a well-established role in the virulence potential of other gram-negative bacteria such as Yersinia $(33,34)$. We recently bioinformatically identified five Type $5 c$ adhesins in the strain $F$. nucleatum 23726 , with four of these (CbpF, FvcB, FvcC, FvcD) containing all of the classic domains that make up a complete adhesin. The fifth protein (FvcE, not characterized) lacks a 'head' domain that is predicted to coordinate adhesion (23). To study these proteins, we made the first complete, single gene knockouts of these six adhesin genes (fadA, fap2, $c b p F, f v c B, f v c C, f v c D$ ) in $F$. nucleatum 23726, as well as multiple gene deletions per strain (Table S1-3) using a new version of a galactose kinase (GalK) genetic system previously used in F. nucleatum (35), as well as many classical studies in Clostridium (36). The details of developing this efficient genetic system and gene deletions used in this study can be found in Figures S1-6 and the Materials and Methods.

We first established that the deletion of galKT, which remains in all of the subsequent mutant strains, did not affect growth (Fig. S3H) and binding to HCT116 cells (Fig. 1E) when compared to wild type (WT) F. nucleatum 23726. We have used the nomenclature Fnn to describe the F. nucleatum $23726 \Delta$ galKT strain throughout the paper and figures (Fig. 1E).

We next show that Fnn $\Delta$ fap2 is significantly attenuated for HCT116 cellular interactions (Fig 1F), but that Fnn $\Delta$ fadA shows no decrease in HCT116 interactions. While FadA has been shown to drive interactions with cancer cells, we note that these studies were done in the strain $F$. nucleatum $12230(31,37,38)$. Upon bioinformatic analysis, we found that $F$. nucleatum 23726 contains four fadA ortholog genes (fadA2, fadA3a, fadA3b, fadA3c), and F. nucleatum 12230 encodes for only one orthologue (23). This could mean that a single deletion of the fadA gene in F. nucleatum 23726 remains adhesive, and that multiple fadA family proteins are contributing to binding and invasion. In addition, a Fnn $\Delta$ fap2 fadA double mutant did not further reduce binding when compared to Fnn $\Delta$ fap2 (Fig. 1F). Concurrently, we analyzed single mutants of the trimeric autotransporter adhesins $c b p F, f v c B, f v c C, f v c D$, as well as a strain lacking all four genes ( $F n n \triangle c b p f f v c B C D)$. We show that $\mathrm{FvcB}, \mathrm{FvcC}$, and FvcD contribute to invasion, albeit less potently than Fap2. Importantly, a Fnn $\triangle$ fap2 cbpf fvcBCD quintuple mutant showed no significant decrease in HCT116 invasion when compared to the single fap2 gene deletion strain. Last, we show that the proportion of intracellular Fnn and Fnn $\Delta$ fap2 determined by antibiotic protection assays (Fig. 1G) correlates with the flow cytometry data, indicating that the trypsinization used to prepare infected HCT116 cells likely removes the majority of surface bound bacteria. Taken together, these data indicate that host cell binding and invasion is largely driven by Fap2. 


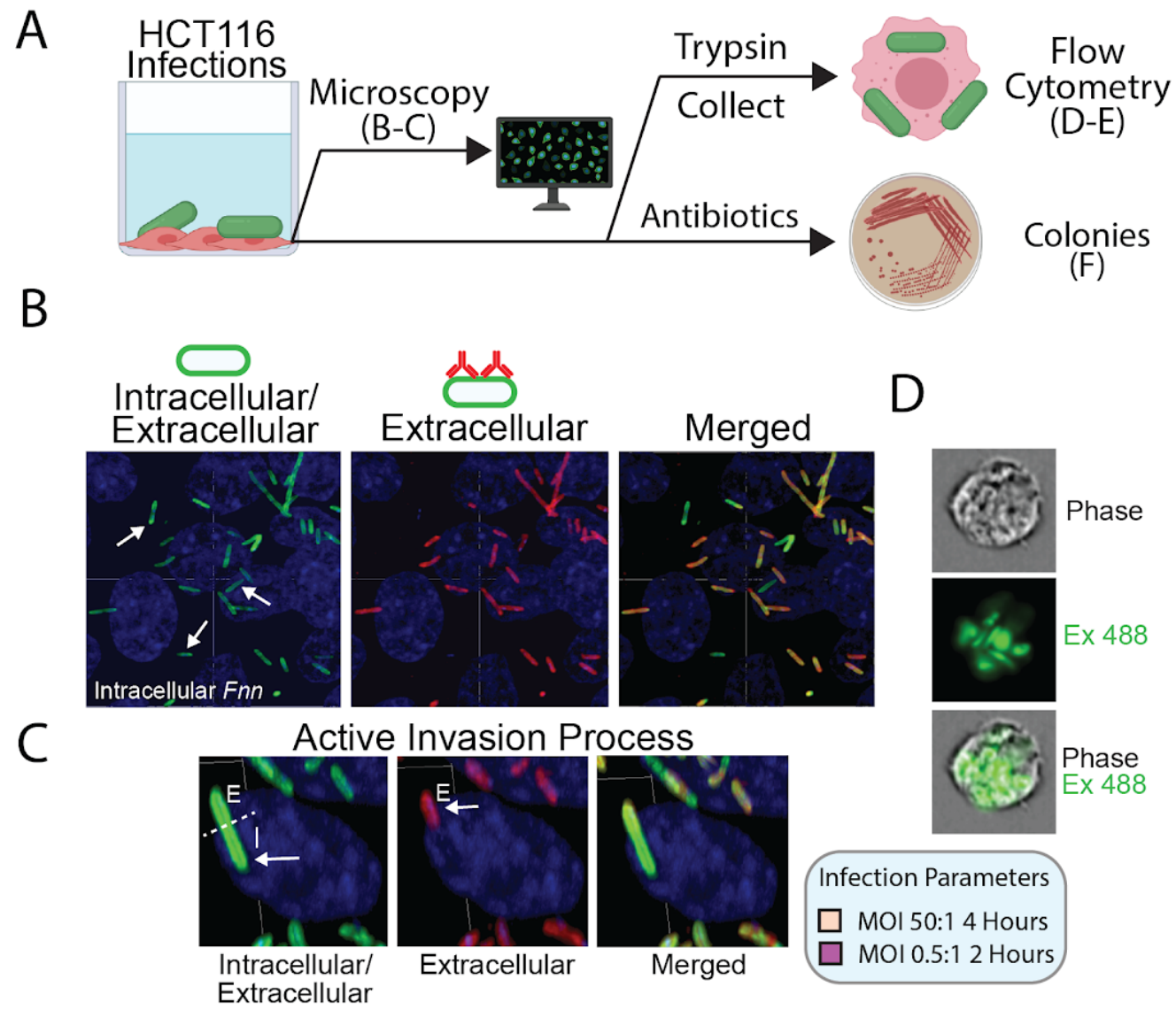

$\mathrm{E}$

\section{$\mathrm{F}$}

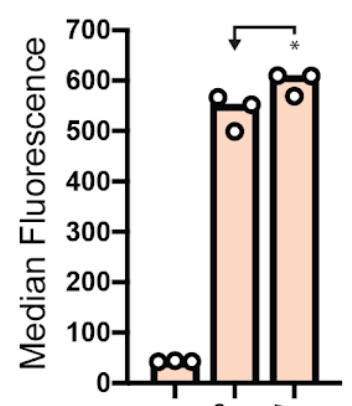

Binding and Invasion
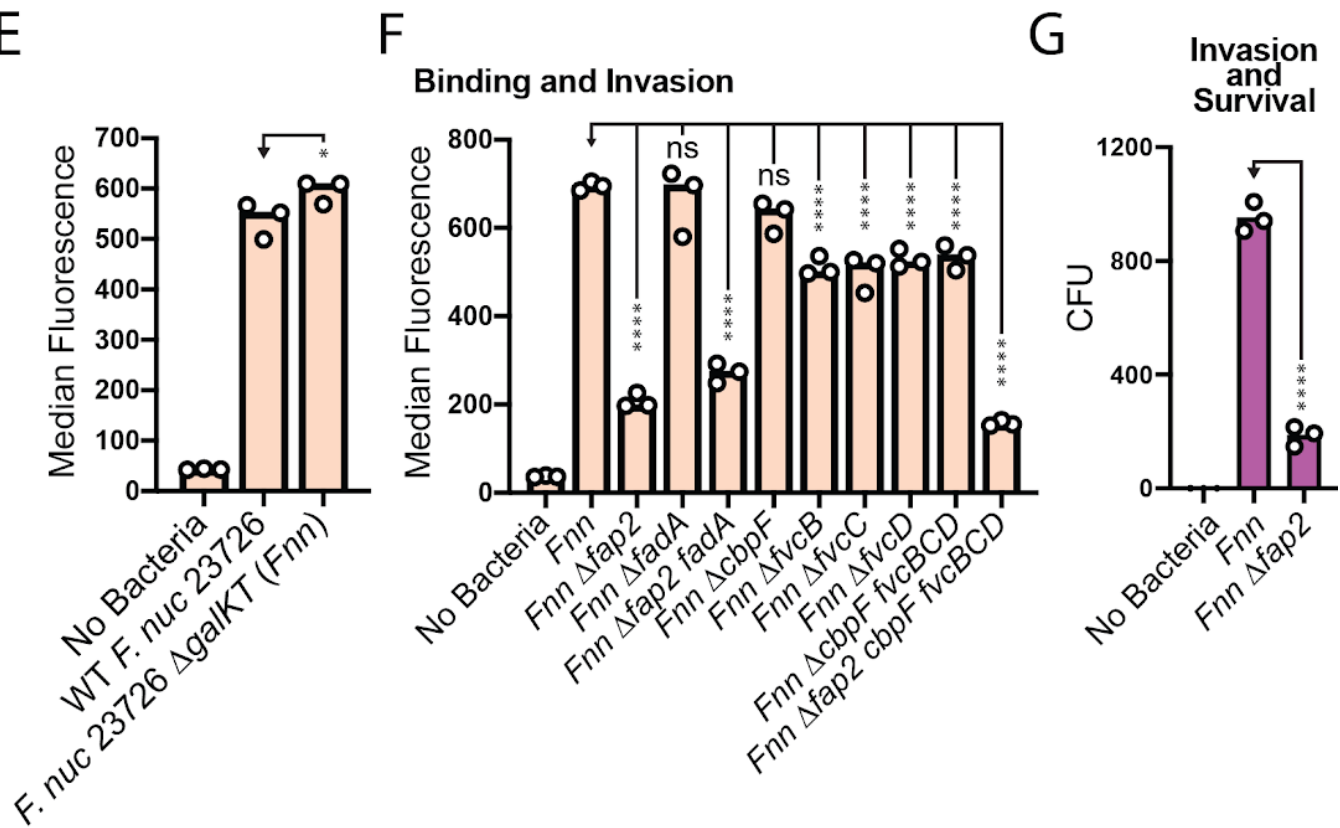

Fig. 1. F. nucleatum binds to and invades HCT116 cells. (A) Overview of experiments used to analyze binding and invasion of Fnn and adhesin mutants in HCT116 CRC cells. (B) Intra- and extracellular Fnn detected with a fluorescent lipid dye (Green, intra- and extracellular) and a pan-Fusobacterium membrane antisera (Red, extracellular), host cell nuclei are stained with DAPI (blue). (C) Zoomed in view and focus on a single Fnn bacterium that is half intracellular, half extracellular. (D) Imaging flow cytometry view of intracellular Fnn. (E) Comparison of HCT116 binding and invasion of wild type (WT) F. nucleatum 23726 with F. nucleatum $23726 \Delta$ galKT (Fnn). (F) Binding and invasion analysis of $F n n$ and adhesin gene deletion strains using flow cytometry. (G) Invasion and survival of Fnn and Fnn $\Delta$ fap2 in HCT116 cells analyzed using an antibiotic protection assay. 
F. nucleatum host-cell binding and invasion is critical for inducing the secretion of pro-inflammatory and pro-metastatic cytokines from cancer cells

After confirming the importance of outer membrane adhesins in invading HCT116 cells, we analyzed the ability of this bacterium to induce the secretion of cytokines from both human cancer cells and mouse neutrophils and macrophages. Using cytokine arrays (Fig. 2A-C), we report that F. nucleatum 23726 interactions with HCT116 cells induces the secretion of high concentrations $(\sim 1000 \mathrm{pg} / \mathrm{mL}$ after four hours) of the CXC family cytokines IL-8 and CXCL1 into the culture medium (Fig. 2D). To determine if direct binding and invasion is necessary for induced cytokine secretion, as well as to rule out whether an unidentified secreted protein or molecule induces this phenomenon, we compared Fnn to Fnn $\Delta$ fap2. Our results show that the ability of Fnn $\Delta$ fap2 to induce cytokine secretion from HCT116 cells is significantly attenuated. This correlates well with reduced invasive potential and confirms direct interaction is needed to alter host cells (Fig. 2D).

To test if this phenomenon was specific to strain F. nucleatum 23726, we compared IL-8 and CXCL1 secretion levels to $F$. nucleatum 25586 and 7_1, which cover subspecies nucleatum and animalis ( $F$ na) respectively. We show that these strains also induce comparable, significant levels of cytokine secretion. Lastly, we compared our 4 hour secretion levels to that of the 24 hour level for $F$. nucleatum 23726 and report an increase in CXCL1 and IL-8 to $\sim 7000 \mathrm{pg} / \mathrm{mL}$ and $\sim 2500 \mathrm{pg} / \mathrm{mL}$ respectively. 
A

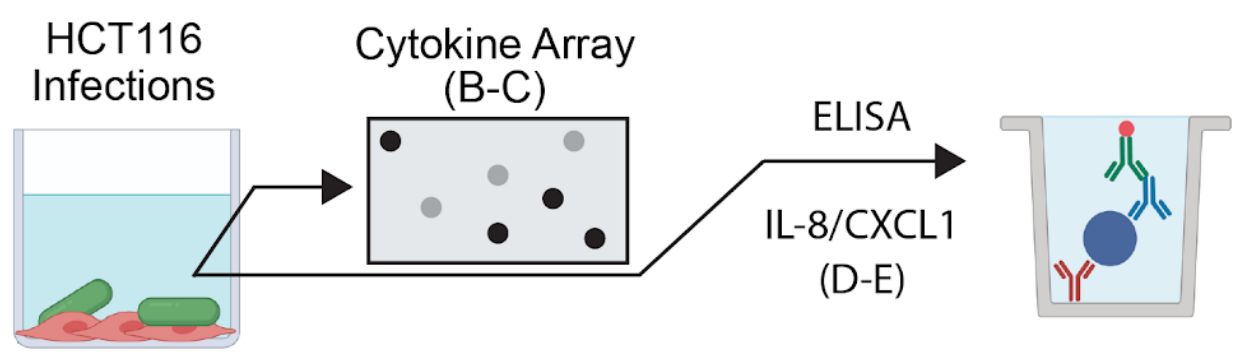

B
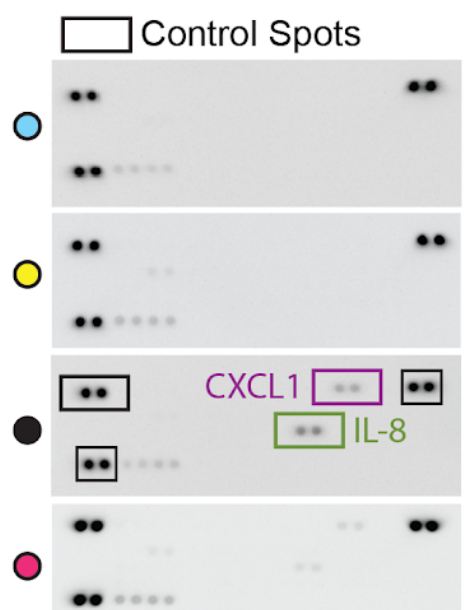

$\bullet$

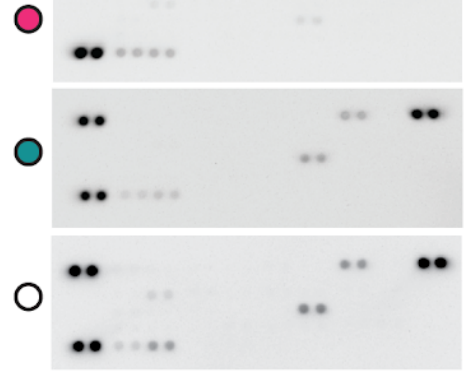

$\mathrm{E}$

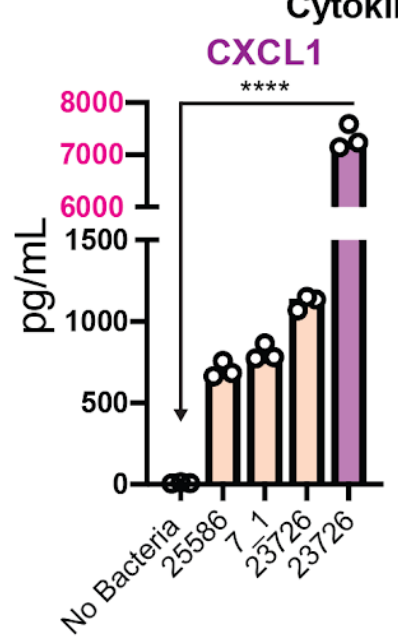

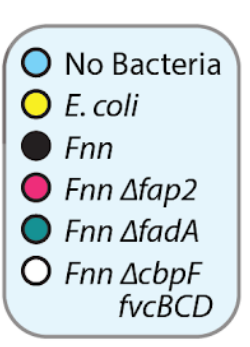

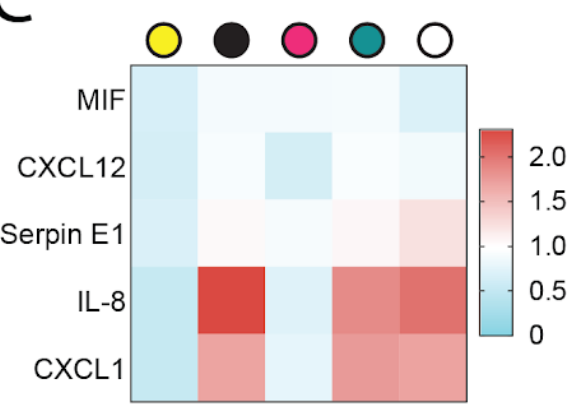

D
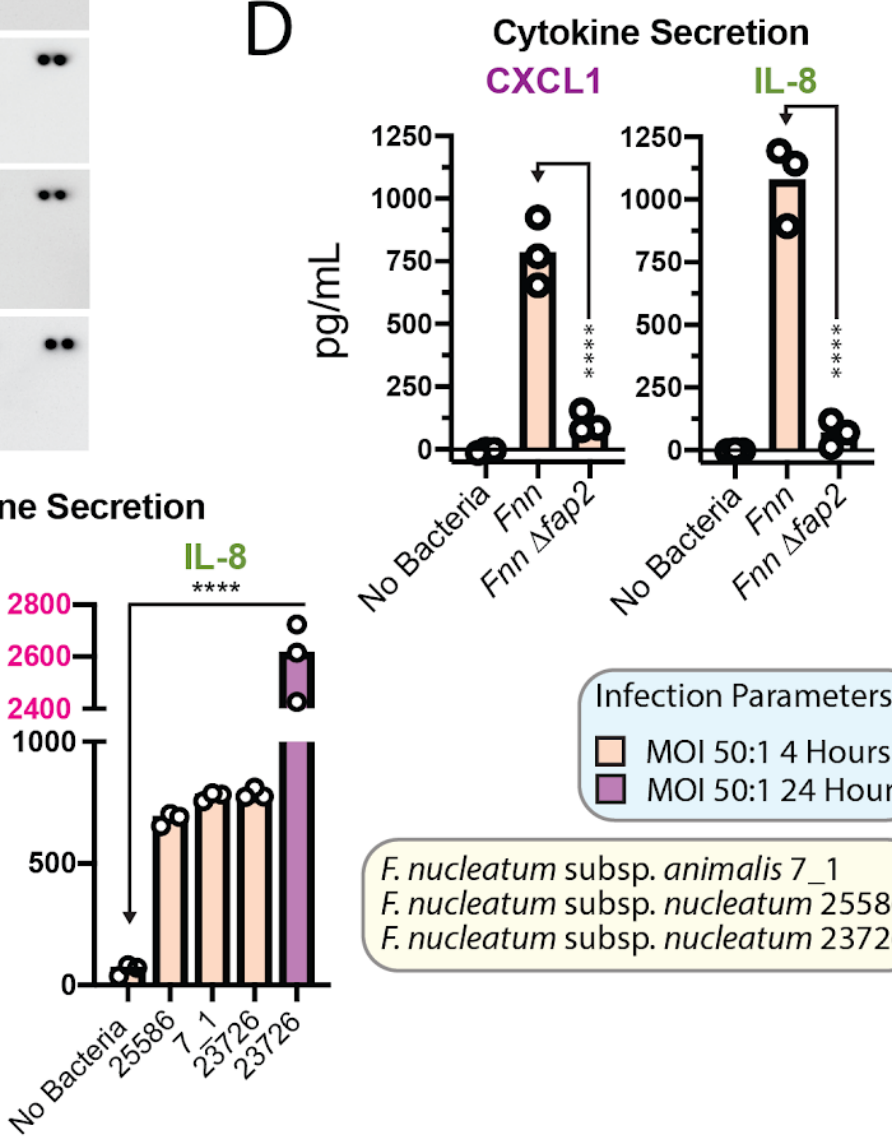

Infection Parameters

MOI 50:1 4 Hours

MOI 50:1 24 Hours

F. nucleatum subsp. animalis 7_1

F. nucleatum subsp. nucleatum 25586

F. nucleatum subsp. nucleatum 23726

Fig. 2. F. nucleatum induces cytokine secretion from HCT116 cells. (A) Overview of experiments used to analyze Fnn induced cytokine secretion from HCT116 CRC cells. (B) Broad cytokine array dot blots analyzing Fnn and Fnn adhesin deletion strains. (C) Heatmap of fold increased dot blot intensity reveals an increase in IL-8 and CXCL1 secretion for invasive strains. (D) IL-8 and CXCL1 ELISA to quantitate cytokine secretion from HCT116 cells induced by Fnn and Fnn $\triangle$ fap2. (E) IL-8 and CXCL1 ELISA to quantitate and compare cytokine secretion from HCT116 cells induced by F. nucleatum subsp. nucleatum 25586, F. nucleatum subsp. nucleatum 23726, F. nucleatum subsp. animalis 7_1 (Fna). 


\section{F. nucleatum induced cytokine secretion in neutrophils and macrophages is not Fap2 dependent}

We characterized cytokine secretion from mouse immune cells using a mouse-specific cytokine array. We first concurrently tested neutrophil cytokine secretion (Fig. 3B), as well as validated the direct binding and potential invasion of neutrophils via fluorescence microscopy (Fig. 3C). F. nucleatum induces the secretion of CCL3, CXCL2, and TNFa, and we validate high amounts of CCL3 and CXCL2 from neutrophils via ELISA (Fig. 3D). In mouse macrophages, F. nucleatum also induces CCL3, CXCL2, and TNFa secretion (Fig. 3E), as well as CCL5 and additional cytokines when compared to either no bacteria or E. coli control infections. CCL3 has a defined role in lymphocyte recruitment in early metastatic CRC (39), and CXCL2 has been shown to promote angiogenesis in CRC tumor microenvironments (40). Interestingly, microscopy shows a smeared DNA pattern from infected neutrophils, potentially indicating the formation of neutrophil extracellular traps (NETs) and a pathway for cytokine secretion (41). F. nucleatum and other oral bacteria were previously shown to degrade NETs, which is a potential escape mechanism from neutrophil-mediated death (42). In stark contrast to the Fap2-driven cytokine secretion seen in HCT116 cancer cells, Fnn $\Delta$ fap2 did not show decreased levels of CCL3 or CXCL2 secretion as analyzed by cytokine arrays and ELISA. We conclude that this shows the importance of Fap2 in selective cancer cell binding, which is evidenced by a lack of Gal/GalNAc sugar on immune cells. In addition, we acknowledge that a role of immune cells is to engulf and clear invading organisms like bacteria, and therefore these cells have acquired the ability to recognize a broad range of bacterial ligands as endocytosis targets. 
A
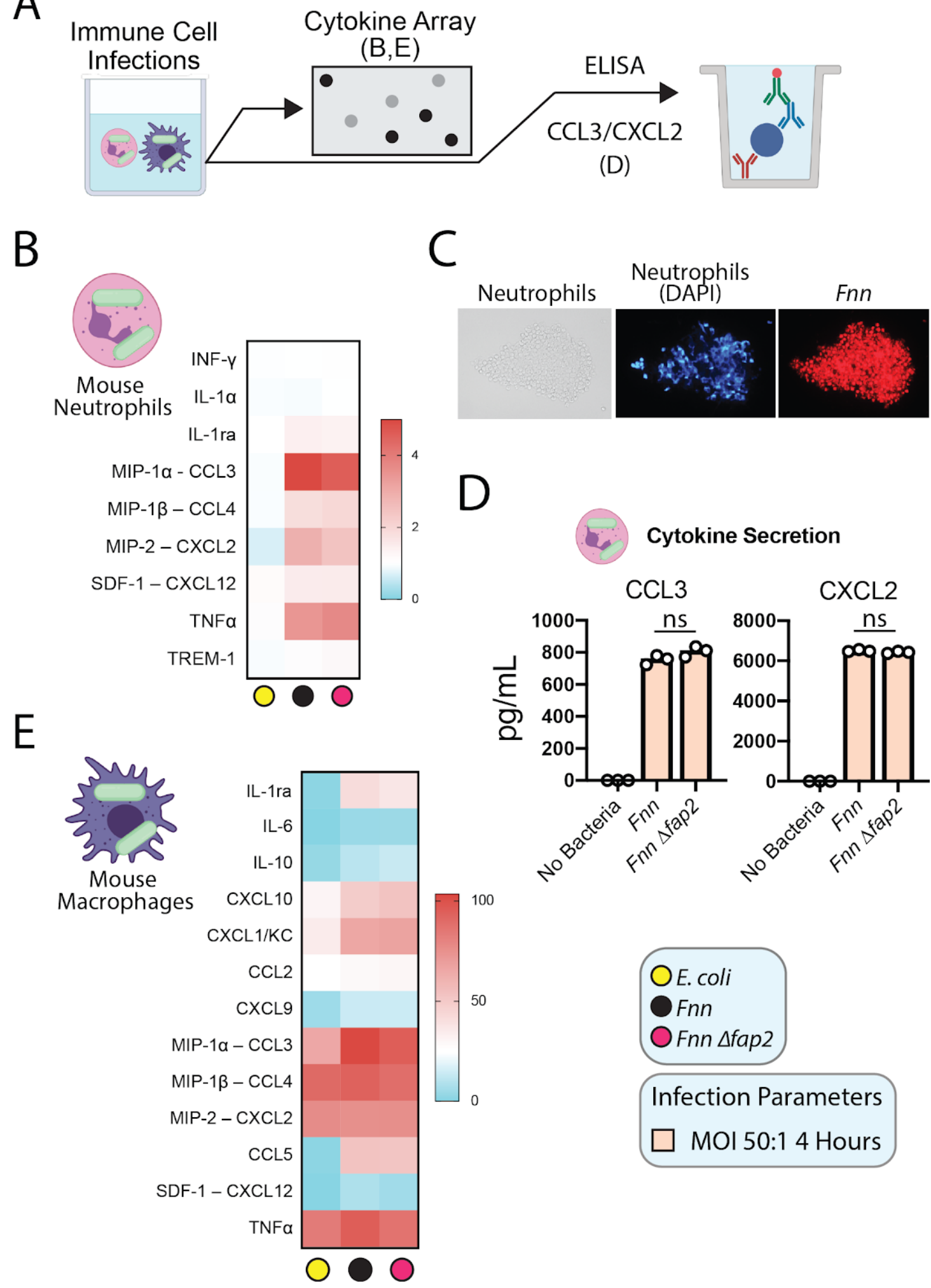

Fig. 3. Cytokine secretion analysis from mouse neutrophils and macrophages. (A) Overview of experiments used to analyze Fnn induced cytokine secretion from immune cells. (B) Mouse cytokine array shows Fnn induced secretion of CCL3, CXCL2, and TNFa from neutrophils. (D) Fluorescence microscopy of Fnn interacting with mouse neutrophils. (D) ELISA confirming Fnn induction of CCL3 and CXCL2, and revealing that deletion of fap2 does not decrease cytokine secretion as it does in HCT116 cells. (E) Mouse cytokine array shows Fnn induced secretion of several cytokines from macrophages when compared to $E$. coli and no bacteria controls. 
Inhibition of bacterial invasion using sugars and arginine blocks cytokine secretion

Since Fap2 is a Gal/GalNAc sugar binding lectin, and this sugar is overrepresented on the surface of CRC cells, we next tested a panel of galactose and non-galactose containing sugars for their ability to inhibit HCT116 binding and IL-8 and CXCL1 secretion. We show that galactose, GalNAc, and lactose (galactose disaccharide) potently inhibit HCT116 binding and invasion, while control sugars including glucose and maltose do not significantly inhibit invasion (Fig. 4A-B). In addition, we tested L-arginine as an inhibitor because the $F$. nucleatum surface adhesin RadD, which is predominantly thought to coordinate interspecies bacterial interactions in the oral biofilm, is an L-arginine inhibitable adhesin (43-45). We show that L-arginine inhibits HCT116 cellular invasion, but not to the extent of galactose sugars. All sugar molecules tested and L-arginine lead to reduced IL-8 and CXCL1 secretion (Fig. 4C), with the most potent being GaINAc as seen in the binding and invasion assay. We believe the addition of $10 \mathrm{mM}$ glucose and maltose results in non-specific inhibition of cytokine secretion, or could be binding to an unidentified F. nucleatum lectin.

Finally, we tested the autophagy and endosome maturation inhibitor chloroquine for its ability to inhibit invasion and signaling (Fig. 4D). This experiment was performed because the two previous studies reporting $F$. nucleatum induced metastasis showed chloroquine is able to inhibit cellular migration, and we set out to test if this is due to reduced cytokine levels $(11,12)$. We show that chloroquine does not inhibit bacterial invasion at $10 \mu \mathrm{M}$, and slightly decreases invasion into HCT116 cells at $50 \mu \mathrm{M}$. In addition, we saw the reverse effect of chloroquine on cytokine signaling, with a slight increase in secreted IL-8 and CXCL1. We elaborate on this finding in the Discussion. 
bioRxiv preprint doi: https://doi.org/10.1101/2020.01.15.907931; this version posted January 16,2020 . The copyright holder for this preprint (which was not certified by peer review) is the author/funder, who has granted bioRxiv a license to display the preprint in perpetuity. It is made available under aCC-BY-NC-ND 4.0 International license.

A

HCT116
Infections

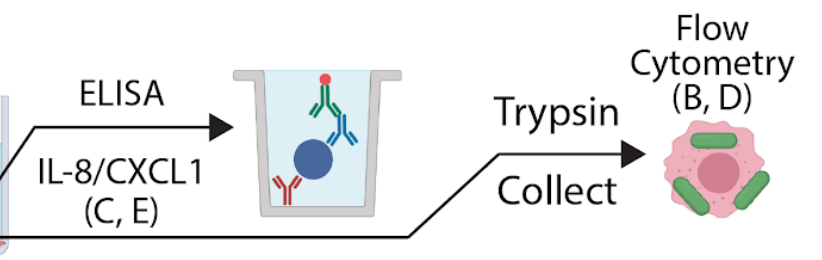

Infection Parameters

MOI 50:1 4 Hours

B

Binding and Invasion

C

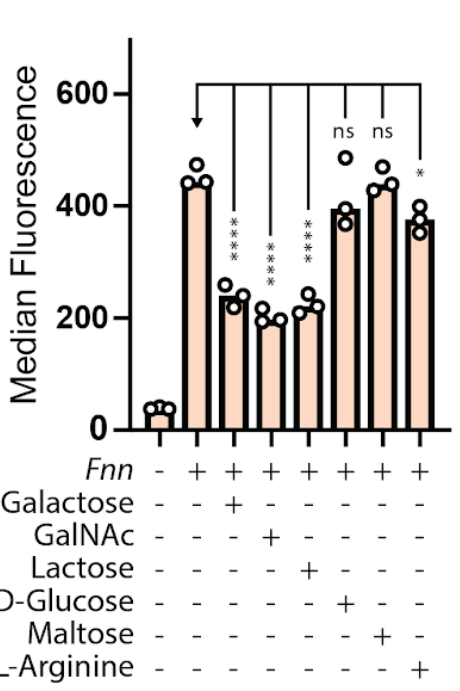

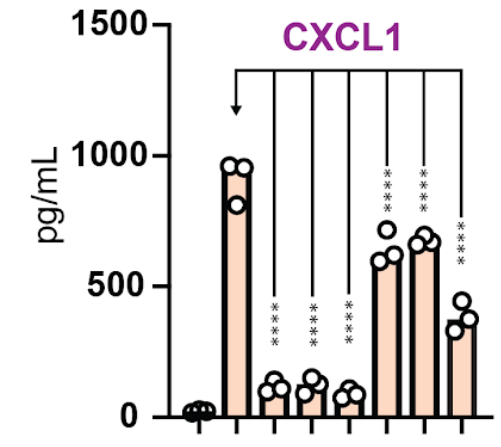

Fnn - +++++++

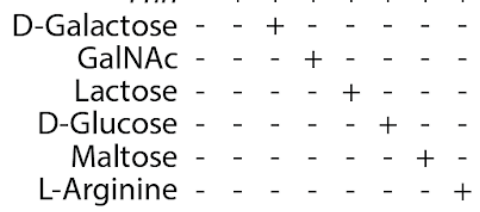

Cytokine Secretion

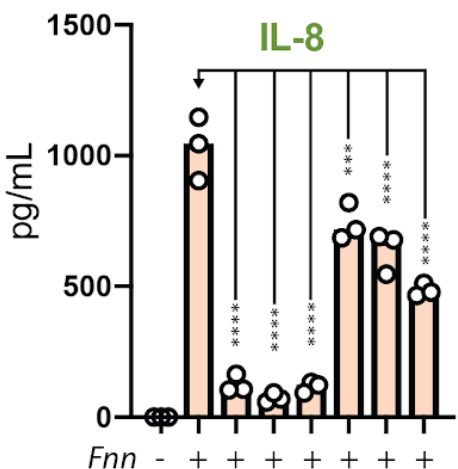

D-Galactose - - + - - -

GalNAc - - - + - - -

Lactose - - - + - -

D-Glucose - - - - + - -

Maltose - - - - - + -

L-Arginine - - - - - - +

D

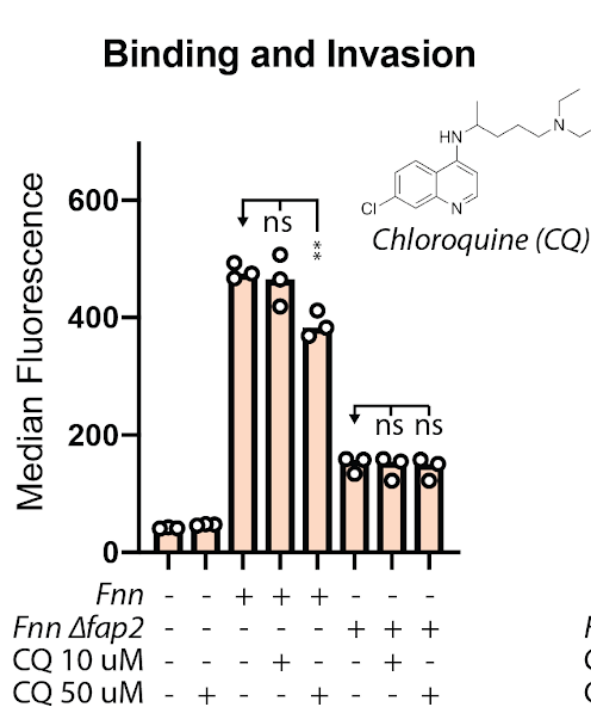

$E$

Cytokine Secretion
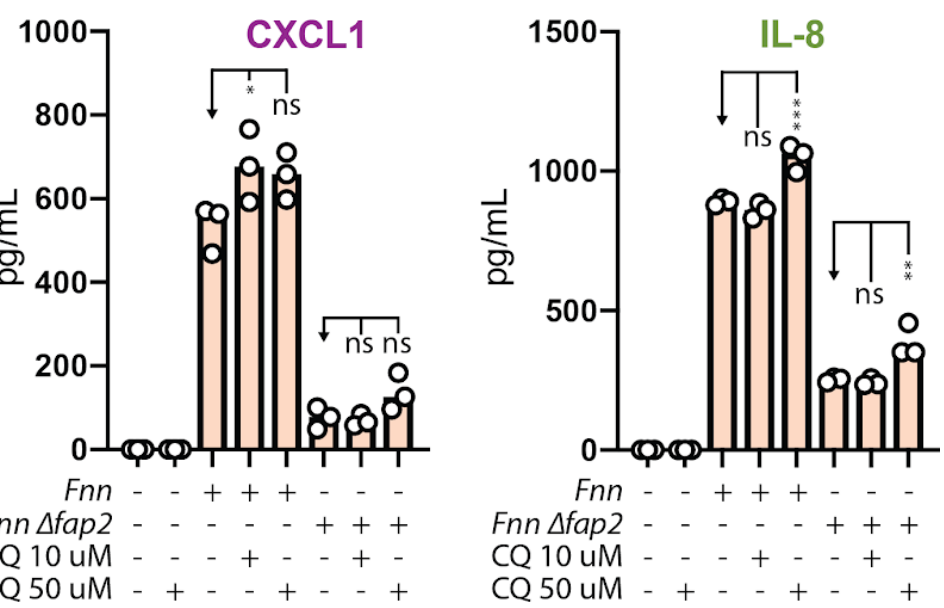

Fig 4. Inhibition of Fnn HCT116 binding and invasion using small molecules. (A) Overview of experiments used to analyze small molecule inhibitors of Fnn binding and invasion of HCT116 CRC cells. (B) Fnn invasion is significantly inhibited by galactose containing sugars and L-arginine $(10 \mathrm{mM})$. (C) Secretion of IL-8 and CXCL1 from HCT116 cells is inhibited by all sugars tested and L-arginine (10 mM). (D) Fnn invasion is not inhibited by $10 \mu \mathrm{M}$ chloroquine (autophagy and endosome maturation inhibitor), and (E) to the contrary could increase CXCL1 and IL-8 secretion. 


\section{IL-8 and CXCL1 induce HCT116 cellular migration}

Based on previous reports of IL-8 induced migration of CRC cells (46), endothelial cells, and leukocytes (47), as well as a role for CXCL1 induced metastasis in multiple cancers including colorectal $(13,18,48)$, we tested their roles in HCT116 migration using transwell assays (Fig. 5A-C). We show that IL-8 and CXCL1 separately induce robust HCT116 migration at $100 \mathrm{ng} / \mathrm{mL}$ (Fig. 5D), but when added together at the same concentration do not additively increase migration.

\section{F. nucleatum conditioned supernatants from HCT116 infections cause cancer cell migration}

After showing that purified IL-8 and CXCL1 induce cancer cell migration, we tested if $F$. nucleatum conditioned culture media from HCT116 infections could cause non-infected cells to migrate. We show through transwell assays that $F$. nucleatum conditioned HCT116 culture media significantly induces non-Fusobacterium exposed cancer cells to migrate starting at 8 hours, with increasing significance through our 16 hour test (Fig. 5E). We subsequently demonstrate that infection with Fnn $\triangle$ fap2, which leads to lower levels of IL-8 and CXCL1 secretion, results in significantly reduced cell migration when compared to Fnn conditioned media (Fig. 5F).

We developed a pan-Fusobacterium membrane antisera (DJSVT_MAS1) to potentially block HCT116 cell migration. However, our results show only a marginal reduction in cellular migration. This could be due to insufficient antibody concentrations added to the assay, or since the anti-sera was developed with 11 strains of Fusobacterium, its specific inhibitory effects on F. nucleatum 23726 have been distributed across non-Fnn proteins. However, the pan-Fusobacterium membrane antisera was able to significantly decrease cancer cell binding (Fig. 5G) and cytokine secretion (Fig. 5H).

Finally, we show that bead-conjugated antibody depletion of IL-8 and CXCL1 from $F$. nucleatum conditioned culture media significantly reduces the amount of migrated cells (Fig. 6), confirming our results with purified cytokines and conditioned media that IL-8 and CXCL1 specifically drive HCT116 cellular migration. As the depletion of these cytokines does not completely abolish Fnn conditioned media induced cell migration, we hypothesize that $F$. nucleatum modulates multiple host proteins and pathways involved in cellular migration and metastasis. We elaborate on this in the Discussion. 


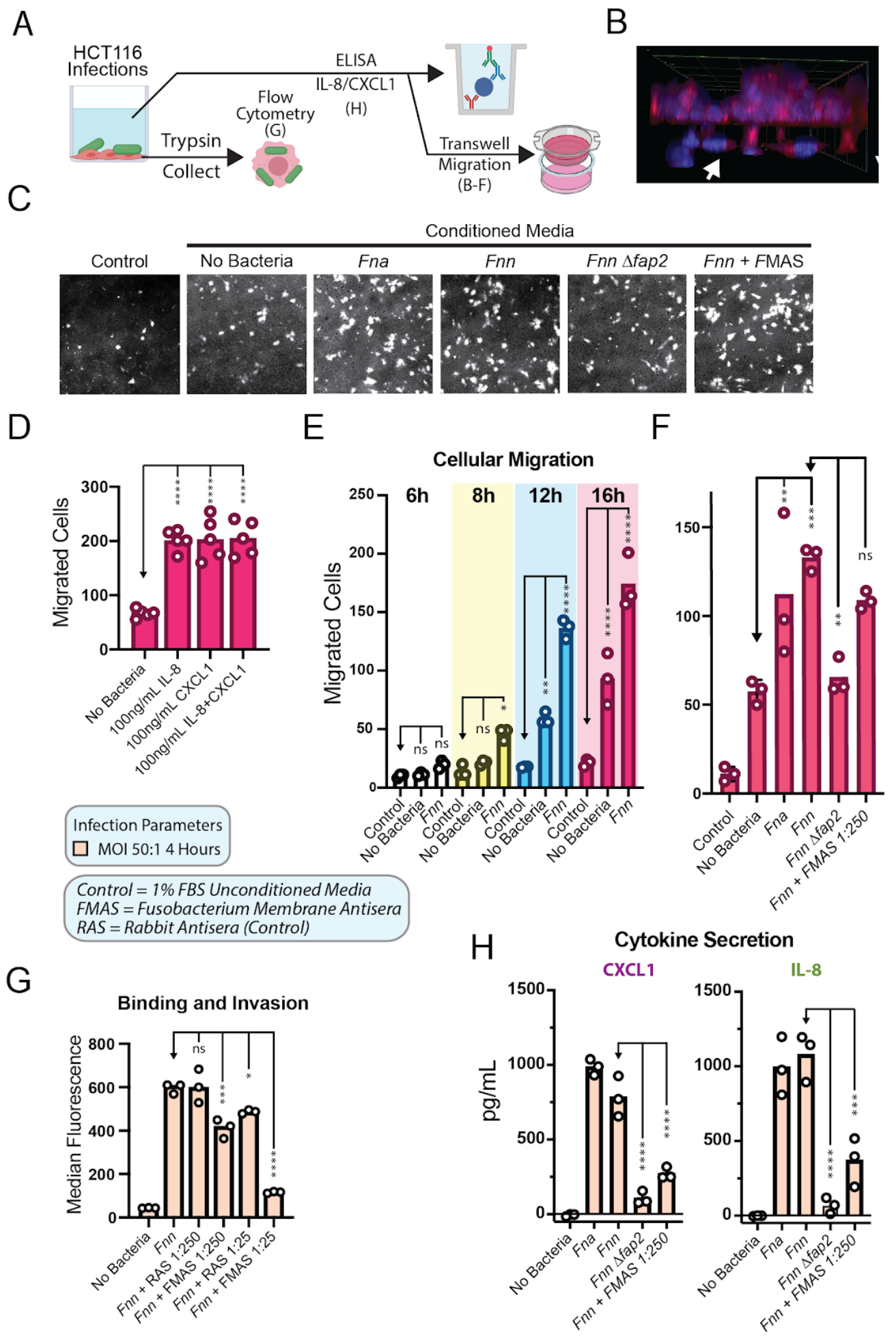

Fig. 5. HCT116 migration is driven by Fnn-induced secretion of CXCL1 and IL-8. (A) Experimental setup of HCT116 transwell migration experiments. (B) 3D confocal image of HCT cells (blue and red) migrated across the transwell barrier (white arrows). (C) Representative images of migrated HCT cells after exposure to the indicated conditioned media. (D) The addition of IL-8 and CXCL1 to culture media within the lower transwell chamber leads to significant HCT116 cancer cell migration. (E) HCT116 cellular migration induced by Fnn conditioned media with high $\mathrm{CXCL} 1$ and IL-8 concentrations. (F) Inhibition of HCT cellular migration through deletion of fap2 (Fnn $\Delta$ fap2) and Fusobacterium membrane antisera (FMAS). (G) Inhibition of HCT116 binding and invasion by Fnn using FMAS and control rabbit antisera (RAS). (H) Inhibition of CXCL1 and IL-8 secretion from HCT116 cells using FMAS. 

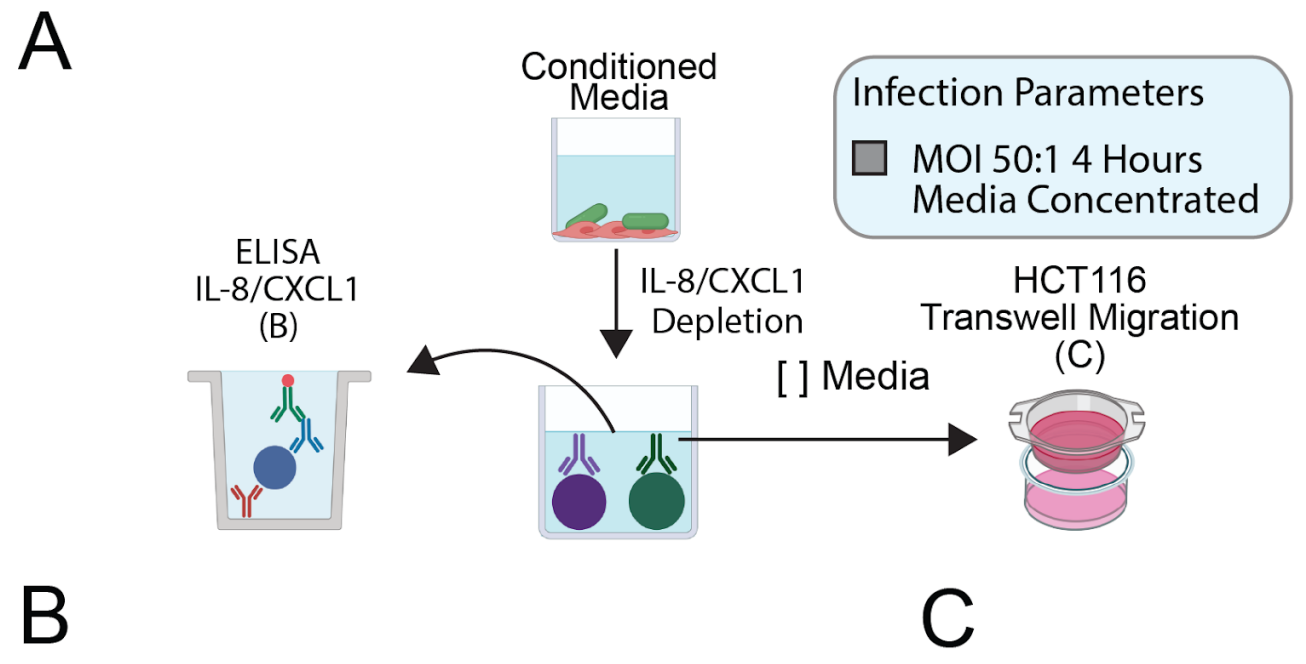

B

Cytokine Secretion
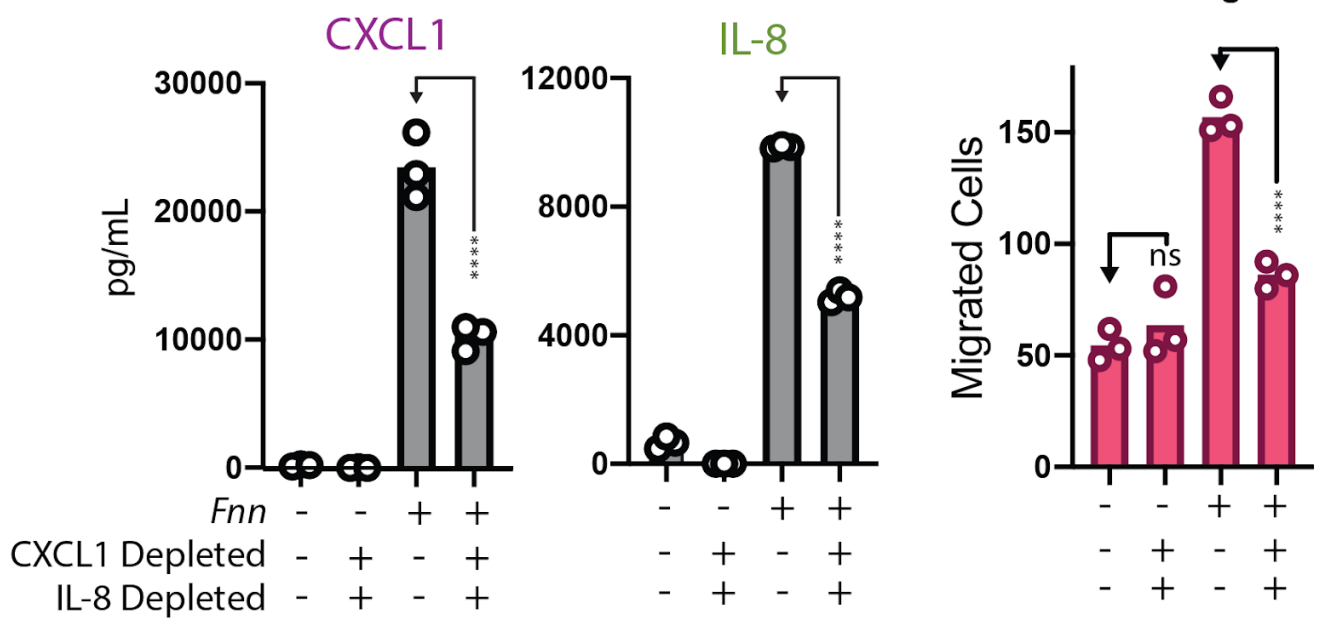

Fig. 6. Depletion of CXCL1 and IL-8 from Fnn conditioned media block cancer cell migration. (A) Experimental setup of HCT116 transwell migration experiments including cytokine depletion from conditioned media. (B) Analysis of CXCL1 and IL-8 levels after concentration, with and without antibody depletion of cytokines and before loading into the bottom chamber of the transwell. (C) Cellular migration is significantly decreased by depleting CXCL1 and IL-8, nearly to the level of non-Fusobacterium conditioned media even through cytokines were not completely depleted. 


\section{DISCUSSION}

Studies have illuminated a strong correlation between the presence of Fusobacterium nucleatum within colorectal tumors and deleterious patient prognosis, which is proposed to be causally related to increased tumor microenvironment inflammation, enhanced oncogenic signaling (49-52). To address the role of $F$. nucleatum in tumor microenvironment signaling, we set out to characterize potential signaling pathways that drive cellular migration and immune cell-driven cancer acceleration. Our data show that direct $F$. nucleatum-cellular interactions with cancer and immune cells, largely coordinated by the outer membrane adhesin Fap2, drive host cells to define a locally pro-metastatic, inflammatory microenvironment. The ability of this bacterium to cause selective induction of the proinflammatory and prometastatic cytokines IL-8 and CXCL1 from CRC cells complements prior studies in which these gross phenotypes of oncogenic acceleration from human patients and mouse models are consistently reported $(10,53,54)$. In addition, our findings add to a growing understanding that $F$. nucleatum directly induces metastasis through cytokine release, increased NF-KB expression and subsequent expression of KRT7 (11), increased CARD3, and downregulation of E-cadherin (12). These studies have now shown active roles for F. nucleatum in mouse models of metastasis, which complement the seminal study by Bullman et al. first reporting viable F. nucleatum within human CRC cell metastases in the liver (Fig. 7) (10).

CXCL1 and IL-8 both play roles in immune cell recruitment, particularly neutrophil recruitment and programming. Through paracrine signaling, F. nucleatum interactions with CRC cells could be releasing factors that create not only a metastatic environment, but one that provides pro-tumor inflammation. There is the potential for recruited neutrophils to be activated to tumor-associated neutrophils (TAN) that could further accelerate tumor progression. In addition, if $F$. nucleatum or the tumor microenvironment then induces neutrophil extracellular trap (NET) formation, these structures have been shown to increase metastasis and sequester circulating tumor cells to promote reseeding (55-57). Finally, it was shown that high intra-tumor loads of $F$. nucleatum resulted lower CD3+ T-cell density in CRC, providing another layer to the complexity of $F$. nucleatum immune cell regulation (58). To address these potential scenarios, a priority should be placed on investigating the potential for this bacterium to induce the formation of additional pro-oncogenic cell types including cancer-associated fibroblasts (CAF) (59), tumor-associated macrophages (TAM) (60), and tumor-associated neutrophils (TAN) (55).

Bacteria such as Streptococcus gallolyticus are known to induce the secretion of IL-8 in colon tumor cells (61). It has also been shown that increased expression of IL-8 leads to a significant resistance to the cytotoxic effects of oxaliplatin, a platinum based chemotherapeutic drug (46). As $F$. nucleatum was previously shown to induce chemoresistance through the induction of autophagy and subsequent inhibition of apoptosis (51), our report of the induction of IL-8 and CXCL1 by this bacterium adds another dimension to this story.

Our data definitively shows the importance of $F$. nucleatum binding and invasion of human cancer cells in producing pro-metastatic cytokines. We and others have proposed that the development of small molecule compounds or proteins that are able to block F. nucleatum docking to host cells could be effective strategies to reduce cancer and immune cell signaling that accelerates metastasis from the colon. A starting point could be the selective inhibition of Fap2, which we have now shown drives binding and cytokine secretion. Fap2 was previously characterized as a lectin and shown to bind to Gal/GalNac sugars that are in abundance on the surface of most cancer cells, especially colorectal (62). The potential for targeting of bacterial lectins for disease treatment has been validated in urinary tract infections by using mannoside sugar derivative compounds that block the uropathogenic E. coli lectin FimH from binding to host receptors, thereby resulting in depletion of this pathogenic bacteria from the gut (63).

Two recent studies report that chloroquine blocks metastasis by lowering $F$. nucleatum-induced NF-kB driven expression of Keratin 7; a protein linked to increased cancer cell motility and invasive potential $(64,65)$, and overexpression of CARD3; a pro-metastatic kinase previously characterized in breast cancer (66). We were therefore interested in whether the IL-8 and CXCL1-regulated cell migration we have observed might be mitigated by chloroquine administration. Our results show that chloroquine treatment actually increased the secretion of IL-8 and CXCL1, suggesting that multiple pathways may be at play in regulating $F$. nucleatum-driven metastasis. This outcome is also the opposite of the effect chloroquine has on reducing the amount of IL-8 secreted upon Campylobacter jejuni infections (67). Taken together these observations could mean the IL-8 and CXCL1 secretion we observed is not caused by a Toll-Like Receptor (TLR) maturation 
dependent mechanism, for which chloroquine has been shown to regulate $(67,68)$, but is still NF-kB dependent. In addition, inhibiting autophagy could lead to increased intracellular survival of $F$. nucleatum. This should be characterized further before these inhibitors are considered for use as more than chemical tools to understand host biological pathways.

As a final point, since the consensus belief is that $F$. nucleatum leaves the oral cavity and traverses the human body through the blood and potentially lymph, it could be advantageous to use a vaccine-based strategy whereby antibodies block and clear this bacterium prior to leaving the bloodstream, thereby preventing downstream tumor interactions. Our data using a pan-Fusobacterium membrane antisera show effective blocking of $F$. nucleatum entry into cancer cells, but this strategy needs refinement to increase strain specific potency. Hence, interfering with $F$. nucleatum interactions in the human body could be a targeted approach that provides an alternative to using non-specific antibiotics. Finally, we hypothesize that future studies characterizing how $F$. nucleatum intricately influences multiple cell signaling pathways during cancer progression and metastasis will lead to targeted approaches for controlling additional oncomicrobes in cancer.

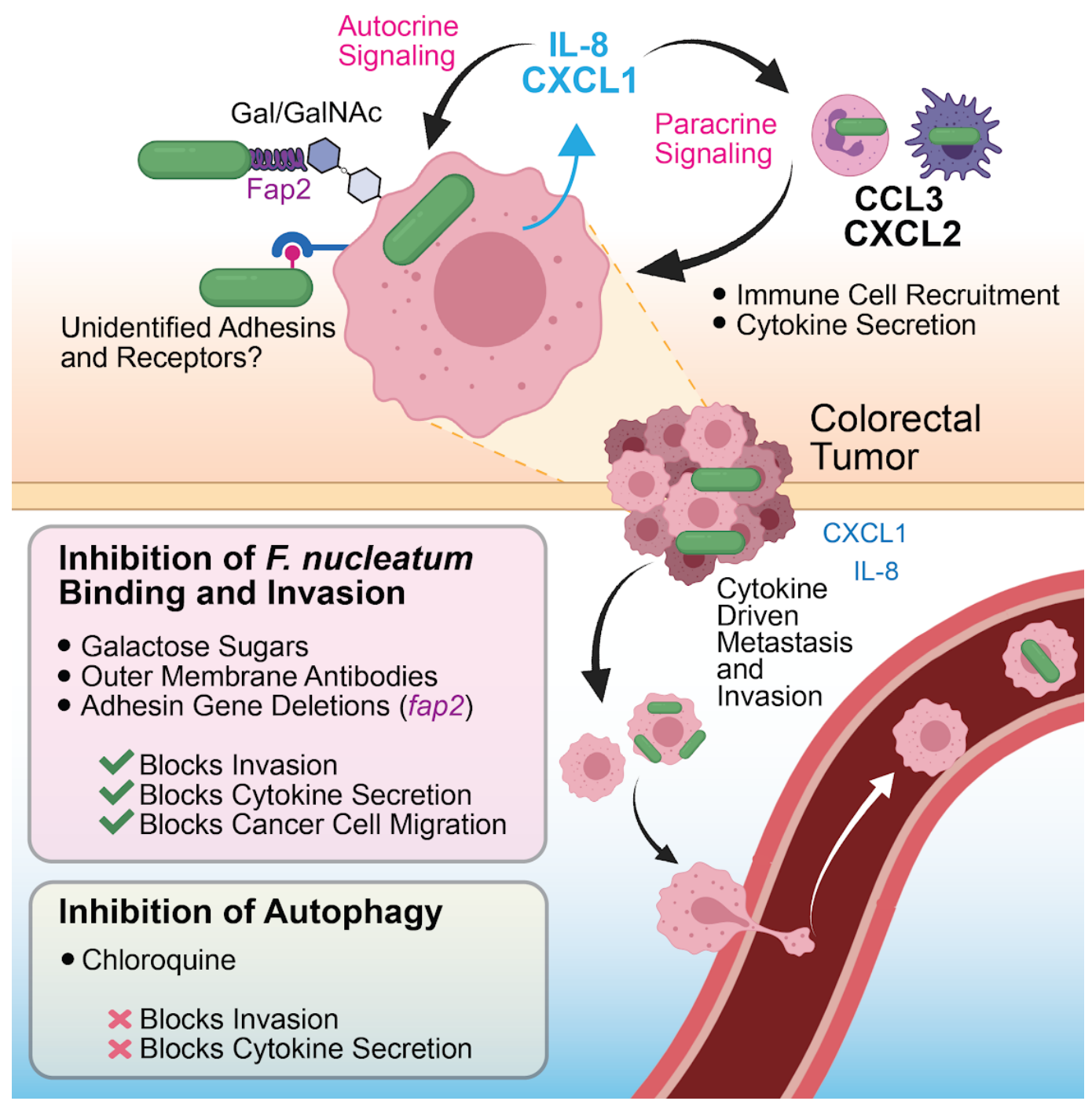

Fig. 7. A model of $F$ nucleatum induced metastasis through cytokine signaling. We show that $F$. nucleatum induces IL-8 and CXCL1 secretion from CRC cells, and both cytokines have been characterized as key players in cancer metastasis and subsequent downstream cell seeding. As well as autocrine signaling back to cancer cells as a metastatic signal, HCT116 derived cytokines can participate in paracrine signaling to recruit neighboring immune cells, which further secrete their own cytokine signatures that alter the tumor microenvironment through metastatic, inflammatory, and immune cell programming. 


\section{MATERIALS AND METHODS}

\section{Culturing Fusobacterium nucleatum}

Fusobacterium nucleatum subsp. nucleatum ATCC 23726, Fusobacterium nucleatum subsp. nucleatum ATCC 25586, and Fusobacterium nucleatum subsp. animalis $7 \_1$ (Fna) were cultured on solid agar plates made with Columbia Broth (Gibco) substituted with hemin $(5 \mu \mathrm{g} / \mathrm{mL})$ and menadione $(0.5 \mu \mathrm{g} / \mathrm{mL})(\mathrm{CBHK})$ under anaerobic conditions $\left(90 \% \mathrm{~N}_{2}, 5 \% \mathrm{H}_{2}, 5 \% \mathrm{CO}_{2}\right)$ at $37^{\circ} \mathrm{C}$. Liquid cultures started from single colonies were grown in $\mathrm{CBHK}$ media under the same conditions. For infections, overnight cultures were back diluted 1:1000 and grown to mid-exponential phase $\left(\sim 0.5 \mathrm{OD}_{600}\right)$ prior to subsequent experiments unless otherwise noted.

\section{Culturing HCT116 CRC cells}

HCT116 (ATCC CCL-247) cells were purchased from ATCC and grown on tissue culture treated plates and flasks in McCoy's $5 \mathrm{~A}$ media supplemented with $10 \%$ fetal bovine serum (FBS), penicillin, and streptomycin. Cells were grown to no more than passage 15 at $37{ }^{\circ} \mathrm{C}$ with $5 \% \mathrm{CO}_{2}$. For maintenance between infections, cells were passaged by gentle trypsinization and reseeding. For infection experiments, cells were grown to $>90 \%$ confluency in 6 or 24 well plates. Unless otherwise indicated, all experiments were conducted with HCT116 media supplemented with $10 \%$ FBS.

\section{Molecular cloning of a galactose selectable gene deletion system.}

We have developed a new iteration of a galactose-selectable gene deletion system in Fusobacterium nucleatum ATCC 23726 (Fnn) capable of deleting an unlimited number of genes in a single strain. We showcase the power of our genetic system by developing strains containing multiple gene deletions from $\sim 300 \mathrm{bp}-12 \mathrm{~kb}$, as well as chromosomally complementing tagged versions of these virulence factors for detection and purification. The plasmids used for these genetic mutations are all new, developed in house, and represented in Table S2. This system is different than a previously reported system in that it relies on the deletion of both the galactose kinase (galK) and galactose-1-phosphate uridylyltransferase ( $g a / T)$ in the Leloir pathway (Fig. S1); ultimately creating a system that allows for the selection of target gene deletions on solid media containing galactose and not the more expensive 2-Deoxy-D-galactose. The first step in creating the chloramphenicol and thiamphenicol selectable plasmid pDJSVT1 was to PCR amplify the catP gene from a pJIR750 backbone (Clostridium shuttle vector) followed by using overlap extension PCR (OLE-PCR) to fuse a pMB1 E. coli origin of replication from pUC19 (Fig. S2A)(See Table S1 for primers). This linear product, which contains a multiple cloning site with GC rich DNA restriction sites (Xhol, Notl, Kpnl, and Mlul) that are optimized for cloning in DNA from AT rich bacteria such as Fusobacterium ( 75\% AT), was cut with Notl and ligated to circularize the plasmid. This final high copy pDJSVT1 construct is small ( 1800 bp), which likely enhances transformation efficiency.

pDJSVT1 is the base vector to create multiple additional vectors to complete the genetic system. To delete the galK and galT genes in F. nucleatum 23726 to make the base strain DJSVT02 (Fig. S3A), 1000 bp directly up and downstream of the galKT gene cluster were amplified separately, then fused using OLE-PCR. This $2 \mathrm{~kb}$ PCR product was then digested with Kpnl/Mlul and ligated into pDJSVT1 digested with the same enzymes. This final vector is pDJSVT13. This vector was electroporated (1-3 $\mu \mathrm{g}$ DNA, $2.5 \mathrm{kV}, 50 \mathrm{uF}$ capacitance, 360 OHMS resistance) into competent $F$. nucleatum 23726 and selection on chloramphenicol (single chromosomal crossover), followed by selection on solid media containing 1\% 2-Deoxy-D-galactose to select for either galKT gene deletions, as the absence of the galT gene makes 2-Deoxy-D-galactose non-toxic to F. nucleatum (Fig. S1).

The next plasmid is for targeted gene deletion in the F. nucleatum $23726 \Delta$ galKT (Fnn: strain DJSVT02) background. This vector, pDJSVT7 (Fig. S2B), contains a FLAG::galK gene under the control of a Fusobacterium necrophorum promoter. Transformation allows for initial chromosomal integration and selection with thiamphenicol, followed by selection for double crossover gene deletions on solid media containing $3 \%$ galactose. For this study, this vector was used to create gene deletions in $f a p 2, f a d A, c b p F, f v c B, f v c C$, and $f v c D$ in F. nucleatum $23726 \Delta$ galKT. As shown in Figure S4, 750 bp directly up and downstream of a target gene for intra-bacteria homologous recombination were amplified by PCR, making complementary fragments fused by OLE-PCR. This product (Fig S4A) is ligated into pDJSVT7 using Kpnl/Mlul restriction sites. This vector is then electroporated $(2.5 \mathrm{kV}, 50 \mathrm{uF}$ capacitance, 360 OHMS resistance) into competent F. nucleatum 
$23726 \Delta$ galKT and selected on chloramphenicol (single chromosomal crossover), followed by selection on solid media containing 3\% galactose which produces either complete gene deletions or wild-type bacteria revertants. Gene deletions are verified by PCR and sequencing, and we show this system has been accurate down to the single base level (Fig. S5). For creating multiple gene deletions in a single strain (Table S3), additional vectors are created and mutants made in sequential fashion, as gene deletion leaves no trace of vectors, including excision of the chloramphenicol and galactose selection genes.

The third vector in the suite, pDJSVT11 (Fig. S2C)(not used in this study), is to create single copy chromosomal complementations at a static chromosomal location within the ars $B$ gene, which is only necessary during times of high arsenic exposure and therefore doesn't change the phenotype of Fnn under any conditions tested (Fig. 1E, Fig. S3H).

\section{RNA Extraction and RT-PCR}

F. nucleatum cultures were grown to stationary phase and pelleted by high-speed centrifugation $(12,000 \mathrm{~g}$ for 2 min at room temperature). TRIzol Extraction Isolation of total RNA was performed following manufacturer's instructions (Invitrogen). Briefly, cell pellets were resuspended in $1 \mathrm{~mL}$ of TRlol reagent (Invitrogen) and 0.2 $\mathrm{mL}$ of chloroform was added. Solution was centrifuged for 15 minutes at $12,000 \mathrm{~g}$ at $4{ }^{\circ} \mathrm{C}$. The RNA-containing aqueous phase was collected and the RNA precipitated after $500 \mathrm{uL}$ of isopropanol had been added. The RNA pellet was then washed with $75 \%$ ethanol and centrifuged at $10,000 \mathrm{~g}$ for 5 minutes at $4^{\circ} \mathrm{C}$. After drying at room temperature for $10 \mathrm{~min}$, the RNA pellet was resuspended in $30 \mathrm{uL}$ sterile RNAse-free water, and solubilized by incubating in water bath at $55^{\circ} \mathrm{C}$ for 10 minutes. Total RNA was quantified using Qubit ${ }^{\mathrm{TM}}$ RNA HS Assay Kit (ThermoFisher).

Before reverse transcriptase (RT)-PCR, RNA samples were subjected to DNAse treatment. Briefly, 500 ng of total RNA was incubated with DNAse I (Invitrogen) for 2 hours at $37^{\circ} \mathrm{C}$. Following treatment, DNAse I was inactivated using EDTA and heating mixture for 5 minutes at $65^{\circ} \mathrm{C}$. (RT)-PCR was performed using the Takara PrimeScript ${ }^{\mathrm{TM}}$ One Step RT-PCR Kit according to the manufacturer's instructions. The PCR conditions consisted of reverse transcription for $30 \mathrm{~min}$ at $50^{\circ} \mathrm{C}$, initial denaturation for $2 \mathrm{~min}$ at $94{ }^{\circ} \mathrm{C}$, followed by 30 cycles (30 sec at $94^{\circ} \mathrm{C}, 30 \mathrm{sec}$ at $50-62^{\circ} \mathrm{C}$, and $30 \mathrm{sec}$ at $68^{\circ} \mathrm{C}$ ) and elongation at $68^{\circ} \mathrm{C}$ for $1 \mathrm{~min}$. The expected bands around $250 \mathrm{bp}$ was confirmed on a $1.5 \%$ agarose gel. Specific primers to detect knockout of gene and validate intact genes upstream and downstream of gene of interest (Supplementary Table 1) were used to amplify from RNA extracts.

\section{Development of a pan-Fusobacterium outer membrane antisera}

To test if broadly-neutralizing polyclonal antisera against Fusobacterium outer membrane proteins could be effective at blocking cellular binding and entry, rabbits were injected (New England Peptide) with purified total membrane proteins from 11 strains of Fusobacterium that span 7 species ( $F$. nucleatum subsp. nucleatum 23726, F. nucleatum subsp. animalis 7_1, F. nucleatum subsp. polymorphum 10953, F. nucleatum subsp. vincentii 49256, F. periodonticum 2_1_31, F. varium 27725, F. ulcerans 49185, F. mortiferum 9817, F. gonidiaformans 25563, F. necrophorum subsp. necrophorum 25286, F. necrophorum subsp. funduliforme 1_1_36S). $20 \mathrm{~mL}$ of each strain was grown as previously described to stationary phase before pooling. $220 \mathrm{~mL}$ of pooled Fusobacterium culture was centrifuged and the pellet resuspended in $40 \mathrm{~mL}$ of phosphate-buffered saline $\mathrm{pH} 7.4$ (PBS) with 2 roche EDTA free protease inhibitor tablets, frozen at $-80^{\circ} \mathrm{C}$, and passed through an Emulsiflux C3 at $>15 \mathrm{k} \mathrm{PSI}$ to lyse cells. Lysate was centrifuged at $18000 \mathrm{~g}$ for 25 minutes to pellet debris and unlysed cells. The supernatant was carefully transferred to ultracentrifuge tubes, and centrifuged in a 50-Ti rotor at 38,000 rpm ( 144kG average) for $1 \mathrm{hr}$ and $40 \mathrm{~min}$. The supernatant was discarded, the membrane protein pellet was gently washed with PBS, and $0.5 \mathrm{~mL}$ of PBS with $1 \%$ BOG was added to each of the two tubes and gently resuspended by stirring overnight at $4{ }^{\circ} \mathrm{C}$. The protein concentration was determined by $\mathrm{BCA}$ prior to shipment to New England Peptide for inoculation into rabbits. The resulting membrane antisera is herein named DJSVT_MAS1, but for clarity is described in Figure legends as FMAS for Fusobacterium membrane antisera. 
Confluent HCT116 cells on slides were infected with FM -143FX labeled (Green fluorescent lipid) F. nucleatum 23726 in wells containing McCoy's 5A media with 10\% FBS and no antibiotics at MOI of 50:1 for four hours at $37{ }^{\circ} \mathrm{C}$ with $5 \% \mathrm{CO}_{2}$. Post infection, media was removed and thoroughly washed with PBS with gentle orbital shaking. Infected cells were then fixed with PBS/3.2\% paraformaldehyde for 20 minutes at room temperature, followed by washing with PBS. Cells were blocked with Sea Block (Abcam) for 2 hours at $37^{\circ} \mathrm{C}$, followed by the addition of 1:100 dilution of DJSVT_MAS1 overnight at $4{ }^{\circ} \mathrm{C}$. Slides were washed in PBS and incubated for 1 hour with Alexa Fluor 594 goat anti-rabbit antibody diluted in Sea Block. After washing with PBS, cells were permeabilized with PBS $/ 1 \%$ Triton X-100 for 20 minutes. Post-permeabilization, cells were washed in PBS and labeled with DAPI for 30 minutes. Following three final PBS washes, coverslips were mounted with $80 \%$ glycerol/0.1M Tris pH 8.5 and sealed onto glass slides. Fluorescence microscopy was performed on a Zeiss LSM 800 confocal microscope.

\section{Flow cytometry}

Mid-log phase F. nucleatum were incubated with $5 \mathrm{ug} / \mathrm{mL}$ FM 1-43FX Lipophilic Styryl Dye to stain outer membranes and allow for green fluorescence detection. After washing in PBS, bacteria were resuspended in PBS at 100x concentration (MOI 50:1) before adding to cultures of HCT116 in media containing $10 \%$ FBS. Infections lasted four hours prior to removing the culture media (in many cases used for ELISAs as described), cells washed twice with PBS, followed by cell recovery using $0.05 \%$ trypsin. After neutralizing trypsin with media containing $10 \%$ FBS, cells were pelleted and resuspended in PBS containing $20 \mathrm{mM}$ EDTA. Cells were loaded onto a Guava easyCyte 5 flow cytometer (Luminex) and 10,000 cells were collected using an initial single cell gate to measure the median green fluorescence induced by intracellular $F$. nucleatum labeled with FM 1-43FX. Post data acquisition, FlowJo 10 software was used to further refine gating to single cells as well as determine median fluorescence of all samples. FlowJo analysis was then transferred to GraphPad Prism for statistical analysis and figure generation. In Figure 1D we show intracellular F. nucleatum 23726 using imaging flow cytometry on an Amnis ImageStream X Mk II. For this experiment, the same protocol for bacterial and HCT116 growth, FM 1-43FX labeling, and infection times were used.

\section{Invasion and survival antibiotic protection assays}

HCT116 monolayers were washed one time with PBS and the cells were incubated in media containing $10 \%$ FBS and no antibiotics. HCT116 cells were then infected at an MOI of 0.5:1 with exponential phase $F$. nucleatum for $2 \mathrm{hrs}$ at $37^{\circ} \mathrm{C}$ with $5 \% \mathrm{CO}_{2}$. After infecting cells for $2 \mathrm{hrs}$, the cell culture media was aspirated-off and cells were washed 2 times with antibiotic-containing cell culture media to remove any unbound bacteria. Cells were then incubated in media containing penicillin and streptomycin (readily kills F. nucleatum 23726) for $1 \mathrm{hr}$ to kill any remaining extracellular bacteria. At the end of the incubation period, cells were washed twice with PBS. Epithelial cells were then incubated with warm sterile water to lyse HCT116 cells. Lysates were plated on CBHK plates and incubated at $37{ }^{\circ} \mathrm{C}$ under anaerobic conditions for $48 \mathrm{hrs}$ followed by colony counting.

\section{Inhibition of $F$. nucleatum:HCT116 binding and signaling using chemical compounds and antibodies}

$F$. nucleatum invasion and induced host cell signaling inhibition by chemical compounds and neutralizing antibodies was analyzed using the standard infection conditions described above. Just prior to adding bacteria, with no pre-incubation time, $10 \mathrm{mM}$ of D-galactose, GalNAc, lactose, D-glucose, maltose, or L-arginine were added to the culture media. For DJSVT_MAS1 Fusobacterium membrane antisera, sera was added from between 1:25 to 1:250 dilutions per infection. Chloroquine was added to HCT116 cells at $10 \mu \mathrm{M}$ for four hours prior to infection, and remained in the culture media during infections. For all compounds, after a four hour infection at $\mathrm{MOI} 50: 1$, binding and invasion was analyzed using flow cytometry.

\section{Isolation of mouse neutrophils and macrophages}

Mouse bone marrow neutrophils were isolated from wild type C57BL/6 mice over a $62.5 \%$ percoll gradient with centrifugation at $1100 \mathrm{~g}$ for $30 \mathrm{~min}$. Purity was $>90 \%$ as determined by flow cytometry analysis with Ly6G+CD11b+ staining. Neutrophils were used immediately after isolation. For mouse bone marrow derived macrophages, bone marrow cells were cultured for 5 days in RPMI 1640 medium supplemented with 10\% FBS, $2 \mathrm{mM}$ L-glutamine, $1 \%$ penicillin/streptomycin, and $10 \mathrm{ng} / \mathrm{mL}$ M-CSF. Fresh medium was replaced every 
other day. Wild type C57BL/6 mice were bred and maintained in the animal facility at Virginia Tech in accordance with the Institutional Animal Care and Use Committee (IACUC)-approved protocol.

\section{Human/Mouse Inflammatory Cytokine Arrays}

Exponential phase $F$. nucleatum 23726 or $F$. nucleatum $23726 \Delta$ fap2 were used to infect HCT116 cell monolayers $\left(100 \%\right.$ confluency $1.2 \times 10^{6}$ cells/well for 6 well plate) in antibiotic free cell culture media for four hours at a multiplicity of infection of 50 bacteria per human cell (MOI: 50:1). For neutrophils and macrophages, $1 \times 10^{6}$ cells in suspension were used. After four hours all media $(1.5 \mathrm{~mL})$ was collected and sterile filtered through $0.2 \mu \mathrm{m}$ filters (Millipore Sigma) to remove and bacterial and human cells from the sample. The cytokine array membranes (R\&D: Proteome Profiler Human Cytokine Array (ARY005B), Proteome Profiler Mouse Cytokine Array Kit, Panel A (ARY006)) were then blocked for one hour in TBS $3 \%$ bovine serum albumin (BSA) at room temperature on a rocking platform. While the membrane was blocking, $1.5 \mathrm{~mL}$ of each sample of collected infection media was incubated with $15 \mu \mathrm{L}$ of the human cytokine array detection antibody cocktail at room temperature for $1 \mathrm{hr}$. After $1 \mathrm{hr}$, the blocking buffer was poured off and the sample/antibody mixture was incubated with the array membrane at $4{ }^{\circ} \mathrm{C}$ overnight. Following incubation with the sample/antibody mixture, the array membrane was washed 3 times with PBS. A streptavidin-HRP conjugate was then added to the membrane and incubated for $30 \mathrm{~min}$ on a rocking platform. The array membrane was then washed 3 times with wash buffer to remove any unbound streptavidin-HRP. After the membrane was sufficiently washed it was incubated with a chemiluminescent substrate solution and results were analyzed using the G:Box gel imaging platform.

\section{ELISA}

HCT116 cells were seeded to confluence in 24-well plates $\left(2 \times 10^{5}\right.$ cells/well at $100 \%$ confluence $)$ and $F$. nucleatum was added to $500 \mu \mathrm{L}$ of these wells at a $\mathrm{MOI}$ of $50: 1$. The plates were then incubated at $37^{\circ} \mathrm{C}, 5 \%$ $\mathrm{CO}_{2}$ for four hours. The media was then collected from the wells, sterile filtered using a $0.2 \mu \mathrm{m}$ filter (Millipore Sigma) and diluted to concentrations within the range of the R\&D Systems DuoKit ELISA to analyze human IL-8 and CXCL1 concentrations. For ELISAs detecting mouse CCL3 and CXCL2, $1 \times 10^{6}$ fresh neutrophils in suspension were used as described for the HCT116 protocol.

\section{Transwell HCT116 migration assays}

Transwell HCT116 migration assays were performed with Corning $8 \mu \mathrm{m}$ Transwell inserts in 24-well plates. HCT116 cells were first cultured in McCoy's 5A (ATCC) to $90 \%$ confluence, followed by collection with trypsin Cells were then stained using CellTrackerRed (ThermoFisher) and resuspended at a concentration of $2 \times 10^{6}$ cells $/ \mathrm{mL}$ in media supplemented with $1 \%$ FBS. $100 \mu \mathrm{L}\left(2 \times 10^{5}\right.$ cells $)$ of the cell suspension was added to the top chamber of the $8 \mu \mathrm{m}$ Transwell insert pre-coated with $100 \mu \mathrm{L}$ Matrigel (Corning) $(250 \mu \mathrm{g} / \mathrm{mL}$ ). The lower chamber contained $600 \mu \mathrm{L}$ of media with $1 \%$ FBS in addition to adding the following: 1) chemokines; purified recombinant human IL-8 (ThermoFisher Scientific) and CXCL1 (Sigma-Aldrich), individually or together at a concentration of $100 \mathrm{ng} / \mathrm{mL}$; 2) conditioned and concentrated media obtained from four hour $F$. nucleatum infections of HCT116 cells. To prepare concentrated media for each sample, three T-75 flasks with confluent HCT116 cells were used. Before infection, the complete media in each flask was replaced with $10 \mathrm{~mL}$ serum-free and PenStrep-free media. The bacteria resuspended in serum-free media were added at 50:1 MOI, and the flasks were incubated in a hypoxic chamber $\left(1 \% \mathrm{O}_{2}\right)$ for four hours. The media containing the cell secretions was collected and pooled from three flasks, spun down at $3000 \times \mathrm{xG}$ for five minutes and passed through a $0.22 \mu \mathrm{m}$ filter. The samples were then concentrated from $30 \mathrm{~mL}$ to $1.5 \mathrm{~mL}$ using a $3000 \mathrm{MWCO}$ Amplico concentrator (Millipore Sigma) at $4{ }^{\circ} \mathrm{C}$. The resulting sample was used for ELISA and Transwell migration assays. The Transwells were incubated at $37^{\circ} \mathrm{C}, 5 \% \mathrm{CO}_{2}$ for $6-16$ hours, after which the cells on the top were removed using a cotton-tipped applicator and migrated cells at the bottom of the membrane were stained with DAPI and imaged on a Zeiss LSM 800 confocal microscope using a 10X objective. ImageJ was used to count the number of cells in 5 representative images per Transwell in biological triplicate (69).

\section{Depletion of IL-8 and CXCL1 from conditioned media}

Conditioned and concentrated media was obtained as described. Human IL-8/CXCL8 biotinylated antibody (R\&D Systems BAF208) and Human/Primate CXCL1/GROa/KC/CINC-1 biotinylated antibody (R\&D Systems 
BAF275) were added to the media to a final concentration of $40 \mathrm{ng} / \mathrm{mL}$ and incubated at room temperature with gentle shaking for 30 minutes. $150 \mu \mathrm{L}$ of magnetic streptavidin particles (Sigma-Aldrich 11641778001) were first washed twice with PBS and spun down at $1500 \times G$ and added to the solution. The mixture was incubated at room temperature with gentle shaking for another 30 minutes. The samples were then spun down at 1500 $x G$, and the supernatant was collected containing the conditioned media with reduced cytokines. An ELISA quantified and confirmed the depletion. This media was subsequently used in transwell migration assays as described.

\section{Statistical analysis}

All statistical analysis was performed in GraphPad Prism Version 8.2.1. For single analysis, an unpaired Student's $t$ test was used. For grouped analyses, Two-way ANOVA was used. In each case, the following $P$ values correspond to star symbols in figures: ${ }^{\text {ns }} P>0.05,{ }^{*} P<0.05,{ }^{* *} P<0.01,{ }^{* * *} P<0.001,{ }^{* * *} P<0.0001$. To obtain statistics, all studies were performed as three independent biological experiments.

\section{Acknowledgements}

Funding. This research was supported by the National Institutes of Health through an NCl R21 Award (grant no. 1R21CA238630-01A1; Slade, Verbridge), an NIAID R01 Award (grant no. 5R01AI136386-03; Li), a National Science Foundation Career Award (grant no. CBET-1652112; Verbridge), The Fralin Life Science Institute at Virginia Tech (Slade), and the USDA National Institute of Food and Agriculture (Slade). We thank the following individuals for help and guidance with these studies: Dr. S. Melville (Virginia Tech) and Dr. C. Caswell (Virginia Tech) for critical insight into bacterial genetics; Dr. J. Lemkul (Virginia Tech) for critical manuscript insights; Melissa Makris from the Virginia-Maryland School of Veterinary Medicine for imaging flow cytometry. Select figures were made with a paid subscription of Biorender.com.

\section{Author contributions}

Michael A. Casasanta, Data curation, Methodology, Formal Analysis, Writing-review and editing; Christopher C. Yoo, Data curation, Methodology, Formal Analysis, Writing-review and editing; Barath Udayasuryan, Data curation, Methodology, Formal Analysis, Writing-review and editing; Blake E. Sanders, Data curation, Writing-review and editing; Ariana Umaña, Data curation, Writing-review and editing; Yao Zhang, Data curation, Writing-review and editing; Huaiyao Peng, Data curation, Writing-review and editing; $A$. Jane Duncan, Data curation, Writing-review and editing; Yueying Wang, Data curation, Writing-review and editing; Liwu Li, Conceptualization, Formal analysis, Supervision, Funding acquisition, Validation, Methodology, Writing-review and editing; Scott S. Verbridge, Conceptualization, Formal analysis, Supervision, Funding acquisition, Validation, Methodology, Project administration, review and editing; Daniel J. Slade, Conceptualization, Data curation, Formal analysis, Supervision, Funding acquisition, Validation, Methodology, Project administration, Writing-original draft, review and editing.

\section{Competing interests}

The authors declare that they have no conflicts of interest with the contents of this article.

\section{Data and materials availability}

Materials are available upon reasonable request or in the future through the Addgene plasmid repository. All data needed to evaluate conclusions are presented in the paper or Supplementary Materials, but additional raw data can be accessed on our Open Science Framework repository at: https://osf.io/kbj2h/

\section{Author ORCIDs}

Michael A. Casasanta: https://orcid.org/0000-0001-6614-9623

Christopher C. Yoo: https://orcid.org/0000-0003-0274-7960

Barath Udayasuryan: https://orcid.org/0000-0003-1543-7873

Blake E. Sanders: https://orcid.org/0000-0002-5841-122X

Ariana Umaña: https://orcid.org/0000-0002-1941-8656

Scott S. Verbridge: https://orcid.org/0000-0002-4074-8799

Daniel J. Slade: https://orcid.org/0000-0001-5634-7220 
Fig. S1. Utilizing the Leloir pathway for targeted gene deletions in bacteria.

Fig. S2. Development of vector for markerless gene deletion in Fusobacterium nucleatum.

Fig. S3. Deletion of the galKT gene operon in F. nucleatum 23726.

Fig. S4. Target gene deletion in F. nucleatum $23726 \Delta$ galKT.

Fig. S5. Validation of markerless fap2 and fadA gene deletions in F. nucleatum $23726 \Delta$ galKT.

Fig. S6. Complementation of gene deletions at the static arsB gene site in F. nucleatum 23726.

Fig. S7. Human and mouse cytokine arrays to detect $F$. nucleatum induced immune signaling.

Table S1. Primer list.

Table S2. Construct list.

Table S3. Bacterial strains list. 
A

Glucose-1-Phosphate

Galactose
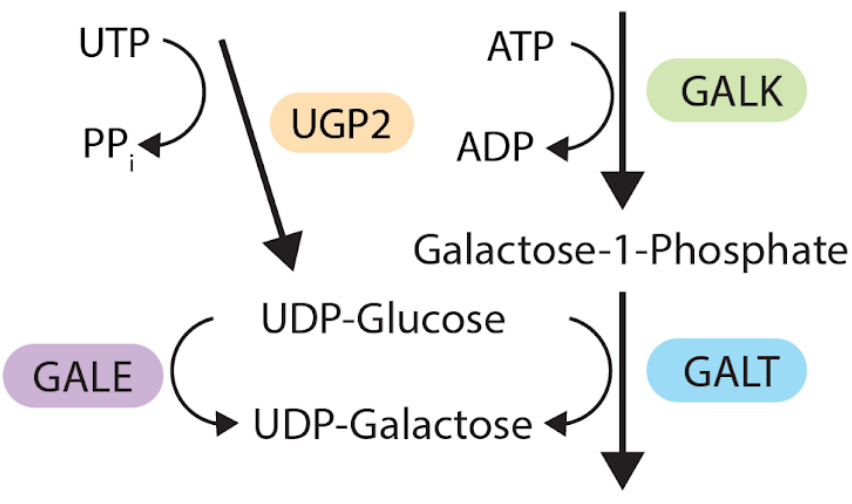

GALK Galactokinase

GALT Galactose-1-Phosphate Uridylyltransferase

UGP2 UDP-Glucose pyrophosphorylase

GALE UDP-Galactose-4'-Epimerase

Glucose-1-Phosphate

B

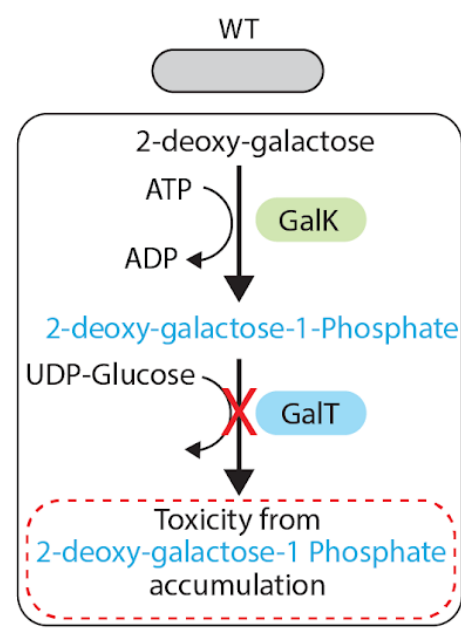

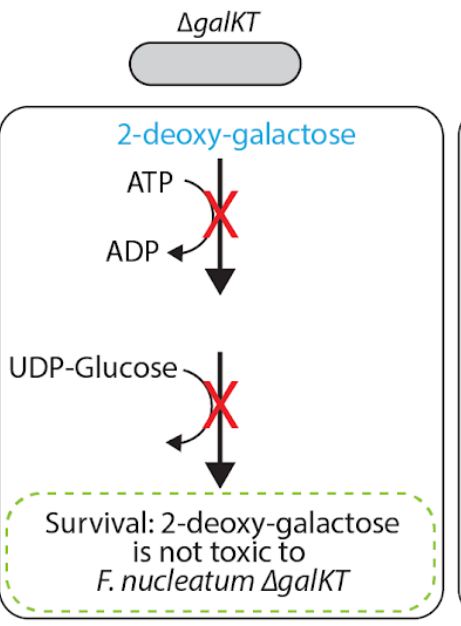

Base strain for all KO

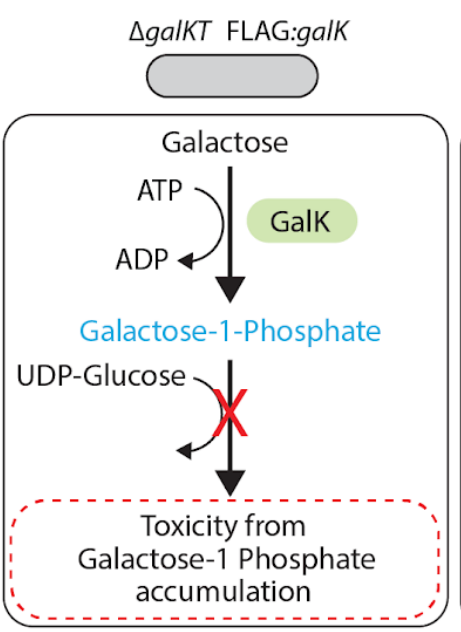

Single crossover

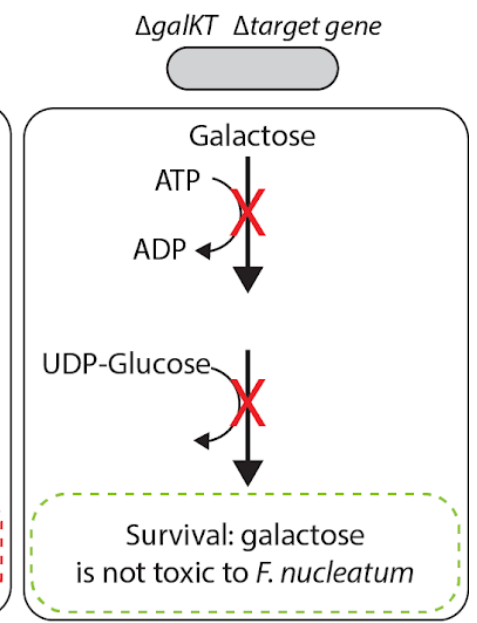

Double crossover gene deletion

Fig. S1. Utilizing the Leloir pathway for targeted gene deletions in bacteria. (A) The Leloir pathway of galactose catabolism. (B) Graphical representation of the different selection stages of $F$. nucleatum gene deletions and how the GalK and GalT affect cellular survival in the presence of galactose and 2-deoxy-galactose. 
A
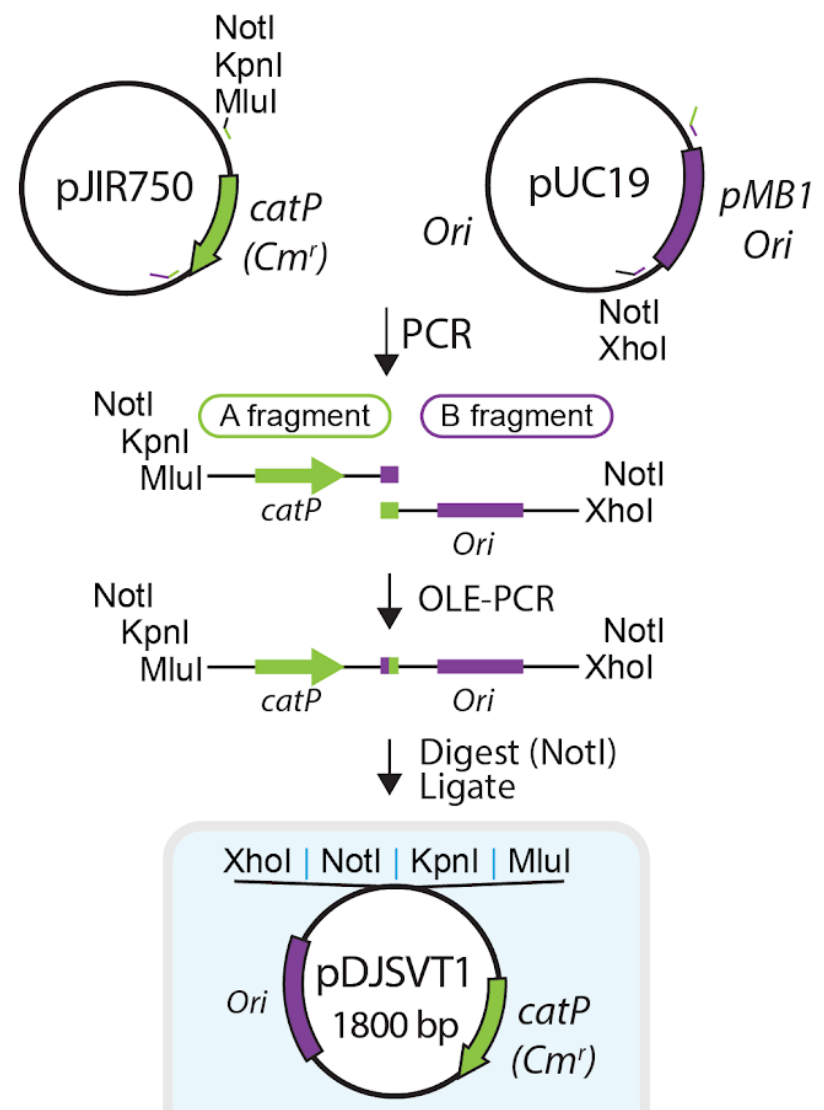

Base vector to make $\mathrm{KO}$ and complementation constructs
B
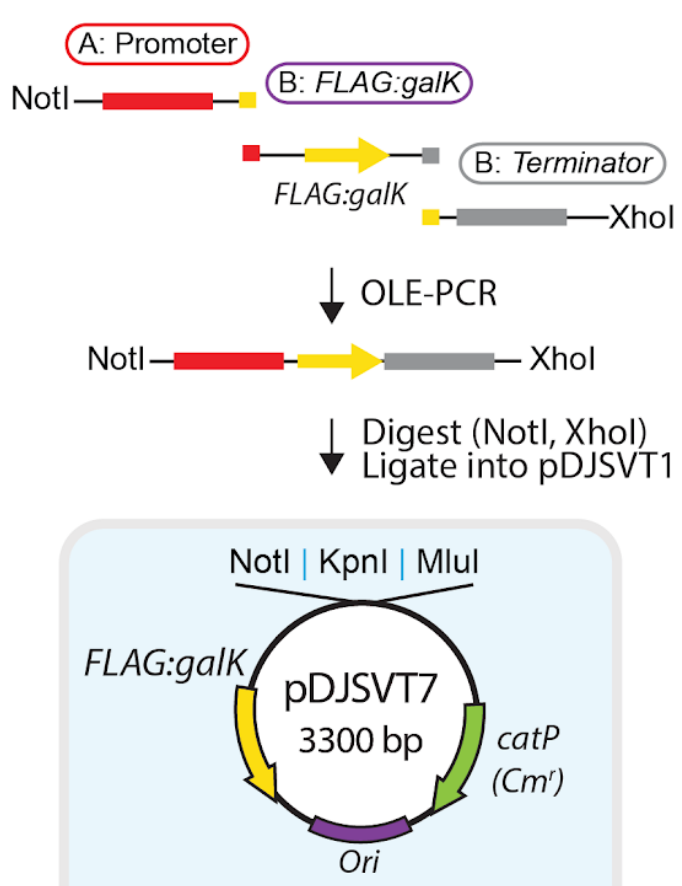

Vector to make target gene $\mathrm{KO}$ in $\triangle$ galKT background
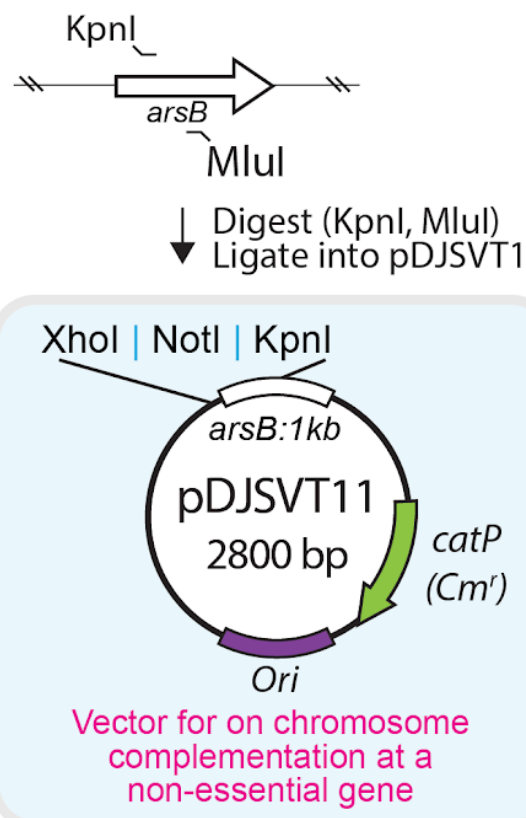

Fig. S2. Development of vector for markerless gene deletion in Fusobacterium nucleatum. (A) Method to create pDJSVT1; the base vector for all gene deletion constructs that consists of an $E$. coli origin and chloramphenicol/thiamphenicol resistance and a GC rich multiple cloning site for efficient cloning of AT rich $F$. nucleatum DNA. (B) pDJSVT7 plasmid incorporation of a constitutively active FLAG:galK gene for selection on 2-deoxy-galactose. (C) Development of a chromosomal complementation vector that incorporates the entire pDJSVT11 plasmid onto the chromosome at the arsB gene in F. nucleatum 23726. 

available under aCC-BY-NC-ND 4.0 International license.

A

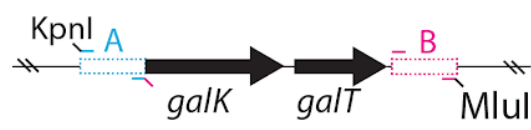

$-1000-1$

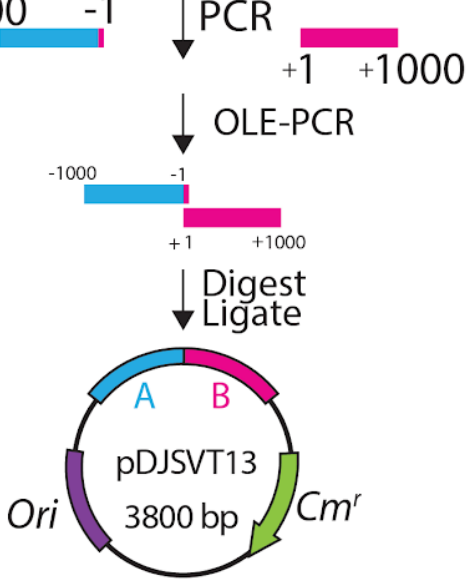

D

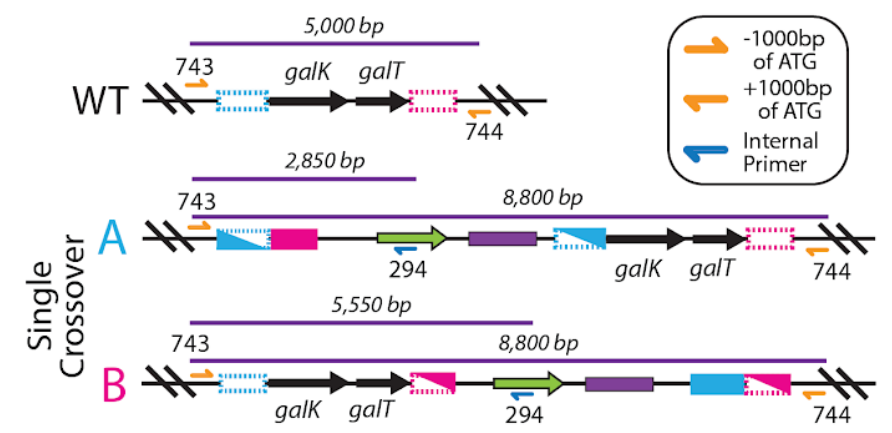

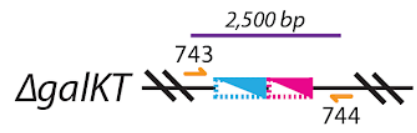

$\mathrm{F}$

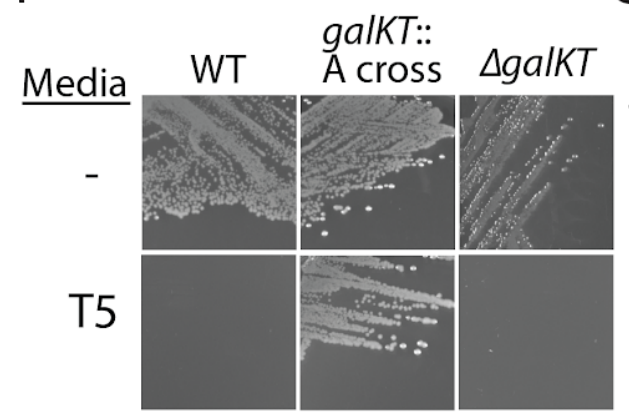

G
B
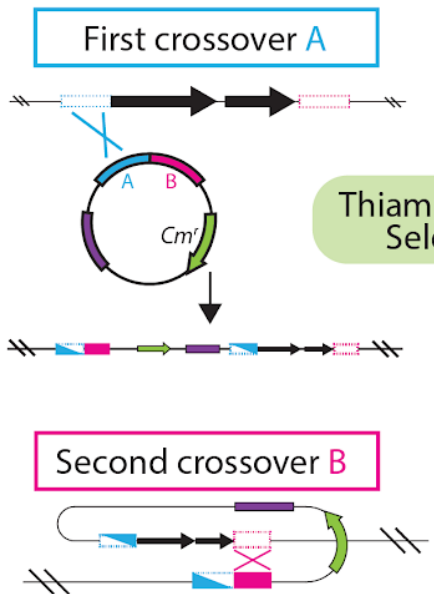

Markerless Gene Deletion
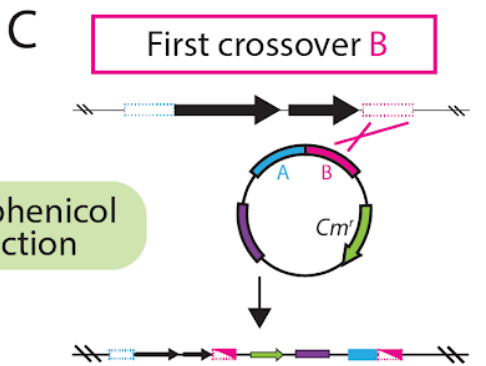

\section{$A: A$ and $B: B$ Crossovers $=W T$ Reversion}

$\mathrm{E}$

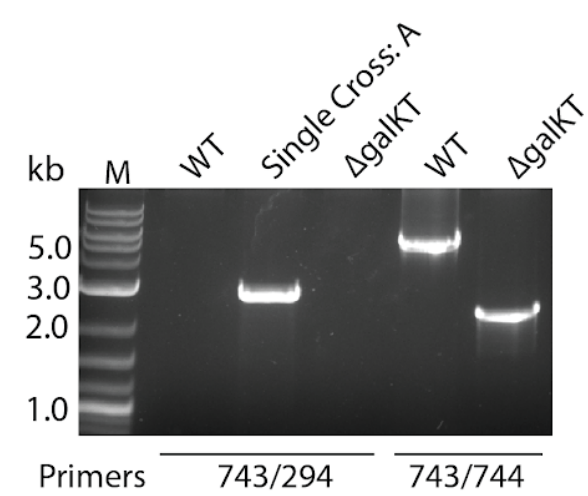

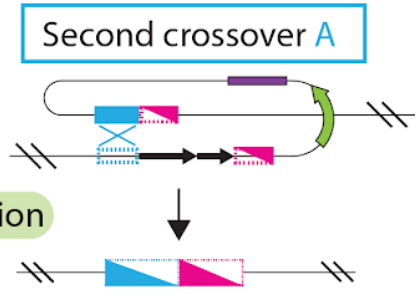

Markerless Gene Deletion

$\mathrm{H}$
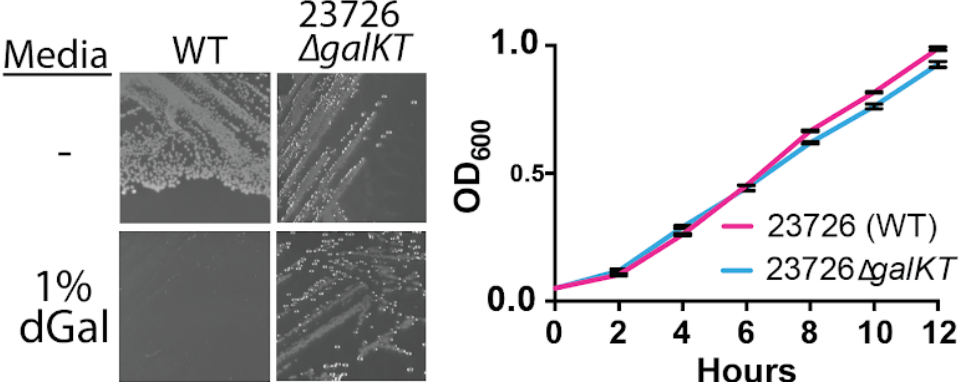

Fig. S3. Deletion of the galKT gene operon in F. nucleatum 23726. (A) Development of pDJSVT13, the plasmid for galKT gene deletion, by inserting 1000 bp galKT flanking sequences into pDJSVT1. (B) Representation of single-crossover homologous recombination onto the $F$. nucleatum 23726 chromosome with either the A (upstream) or (C) B (downstream) 1000 bp DNA fragments in pDJSVT13 followed by showing how the double crossover results in complete plasmid excision. (D) Map of chromosomal plasmid incorporation after the initial single-crossover insertion. (E) PCR verification of single-cross pDJSVT13 and subsequent double-crossover deletion of the galKT operon. (F) Plating on $5 \mu \mathrm{g} / \mathrm{mL}$ thiamphenicol (T5) (single-crossover selection) and (G) 1\% 2-deoxy-galactose (double-crossover), resulting in galKT operon deletion. (H) Validation that $F$. nucleatum $23726 \Delta$ galKT grows the same as WT F. nucleatum 23726. 
bioRxiv preprint doi: https://doi.org/10.1101/2020.01.15.907931; this version posted January 16,2020 . The copyright holder for this preprint (which was not certified by peer review) is the author/funder, who has granted bioRxiv a license to display the preprint in perpetuity. It is made available under aCC-BY-NC-ND 4.0 International license.

A

B
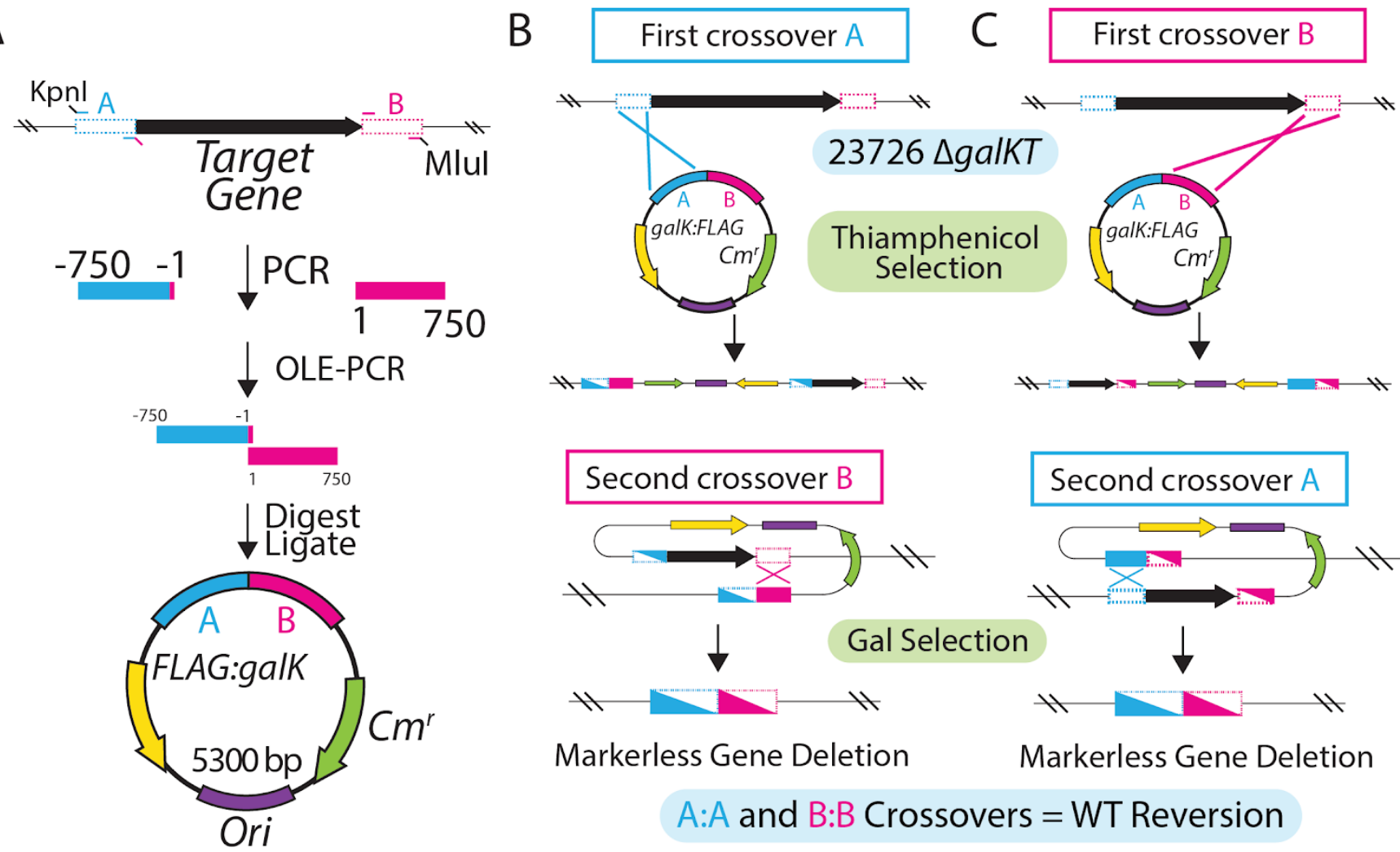

Markerless Gene Deletion

Markerless Gene Deletion

\section{$A: A$ and $B: B$ Crossovers $=$ WT Reversion}

$\mathrm{D}$
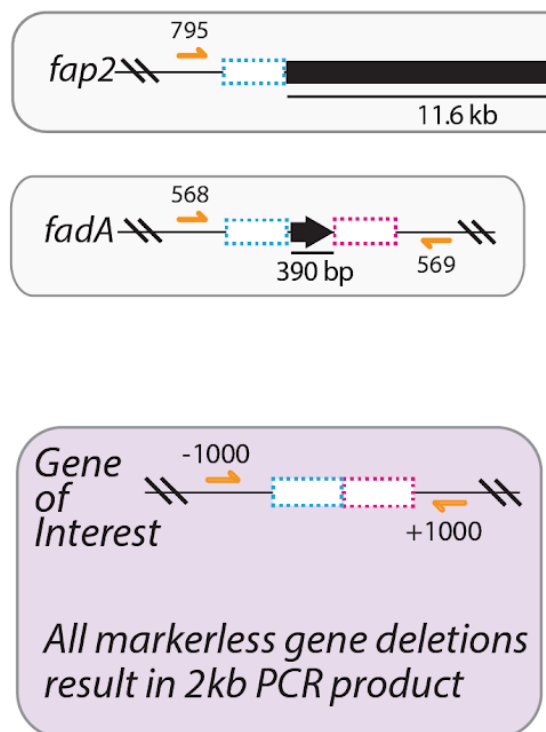

$\mathrm{E}$

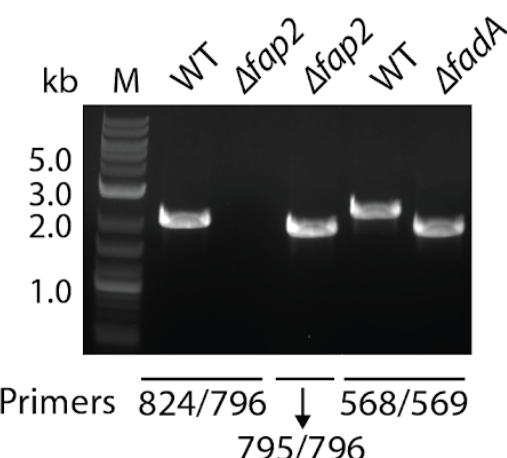

F

\begin{tabular}{|c|c|c|}
\hline \multicolumn{3}{|c|}{ Select F. nucleatum 23726 gene deletion strains } \\
\hline Gene KO & $\sim$ Size deletion in bp & Gene Description \\
\hline$\Delta g a l K T$ & 2,699 & Base Strain for all future mutations \\
\hline$\triangle g a l K T \Delta f a p 2$ & 11,361 & Type 5 a autotransporter adhesin \\
\hline$\triangle g a l K T \Delta f a d A$ & 390 & Small adhesin \\
\hline$\triangle g a l K T \Delta f a p 2 \Delta f a d A$ & $11,361: 390$ & Double Mutant: Both adhesins \\
\hline
\end{tabular}

Fig. S4. Target gene deletion in F. nucleatum 23726 sgalKT. (A) Development of all target gene deletion plasmids (Table S2) by inserting $750 \mathrm{bp}$ from target gene flanking sequences into pDJSVT7. (B) Representation of single-crossover homologous recombination onto the $F$. nucleatum 23726 chromosome with either the A (upstream) or (C) B (downstream) 750 bp DNA fragments. Double crossover results are shown during complete plasmid excision. (D) fap2 and fadA as examples of gene excision. KO validation primers are shown flanking genes at -1000 and $+1000 \mathrm{bp}$. This results in $2 \mathrm{~kb}$ PCR products as shown in (E) for the fap2 and fadA gene deletions. (F) Table of select deleted genes in this study and their function. 
A
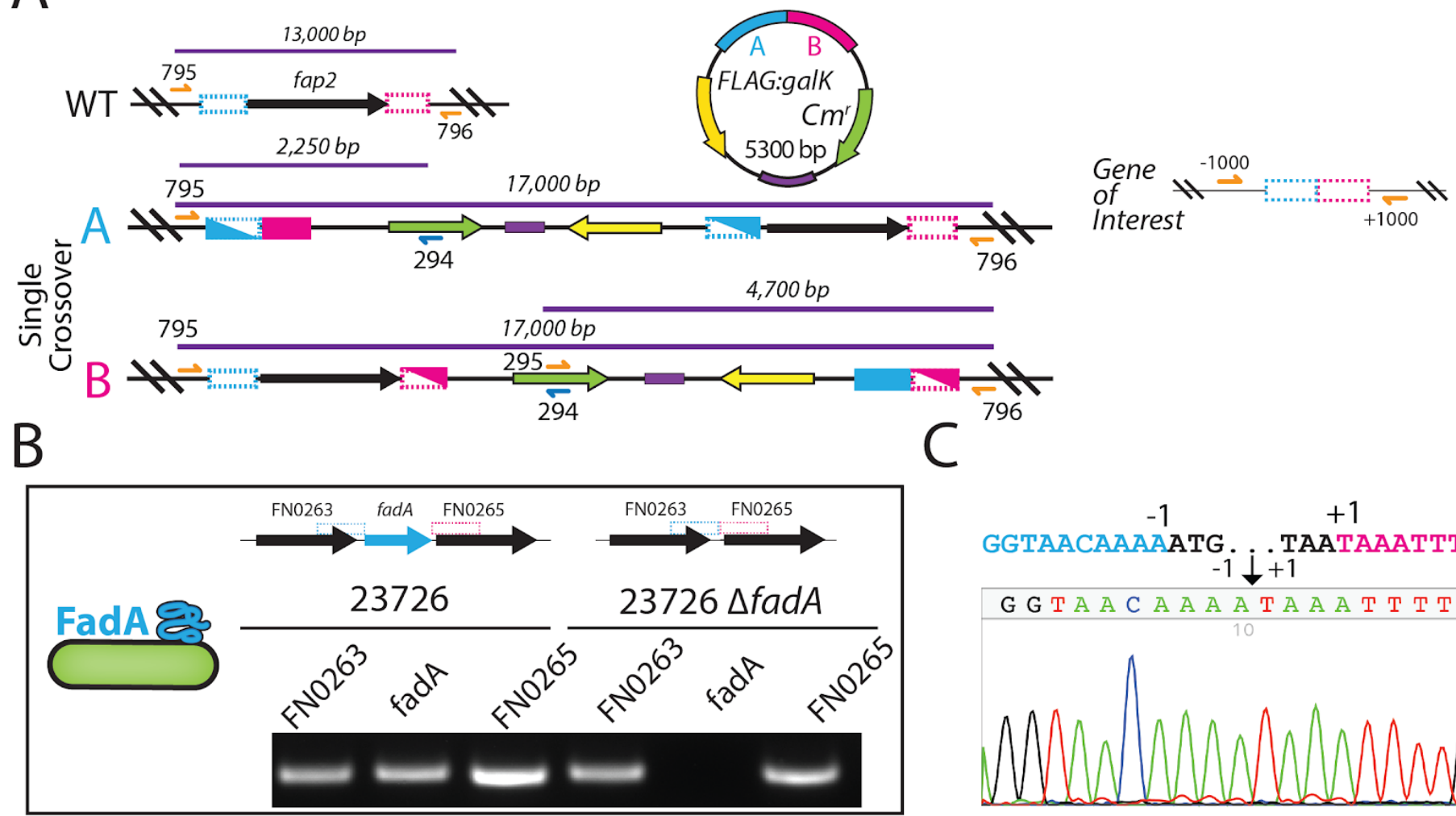

$-1+1$

GGTAACAAAAATG. . TAATAAATTTTGA $-i \mathfrak{i}+1$

G G TACA A A A $\mathrm{TA} A \mathrm{~A} T \mathrm{~T} T \mathrm{TA}$

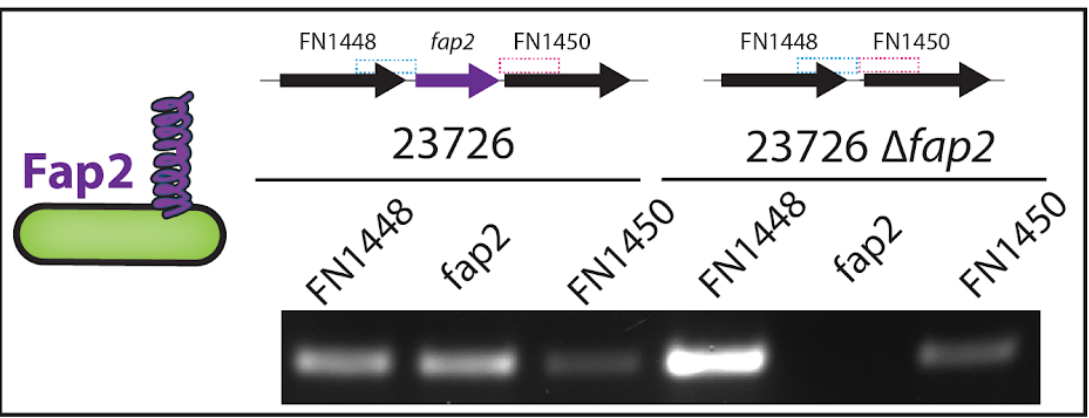

GGAAATTATAATG . . TAATTAAAAAGGC $-1 \downarrow+1$

G GAAATATAT TAAAA A G G C

Fig. S5. Validation of markerless fap2 and fadA gene deletions in F. nucleatum $23726 \Delta$ galKT. (A) Map of chromosomal plasmid incorporation after the initial single-crossover insertion for fap2. (B) RT-PCR of fadA and fap2 with their two surrounding genes showing loss of gene transcription due to gene deletion. (C) DNA sequencing with primers sitting -250 and +250 from the start codon of fadA and fap 2 . All constructs created are $100 \%$ accurate and show perfect excision and recission of the genome to the -1 and +1 base for each gene. 


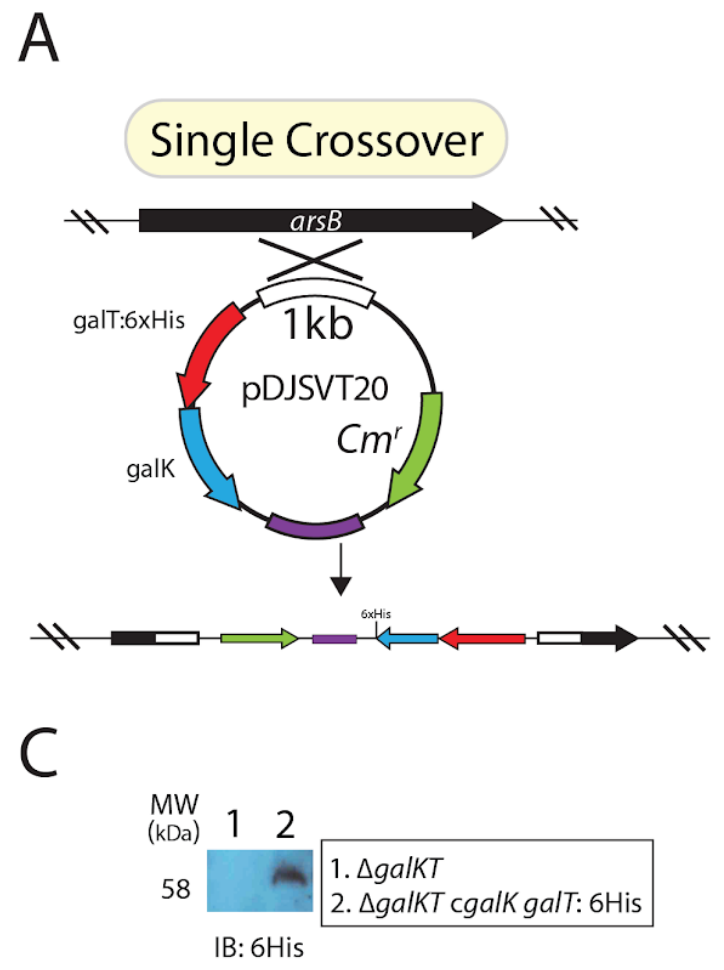

B

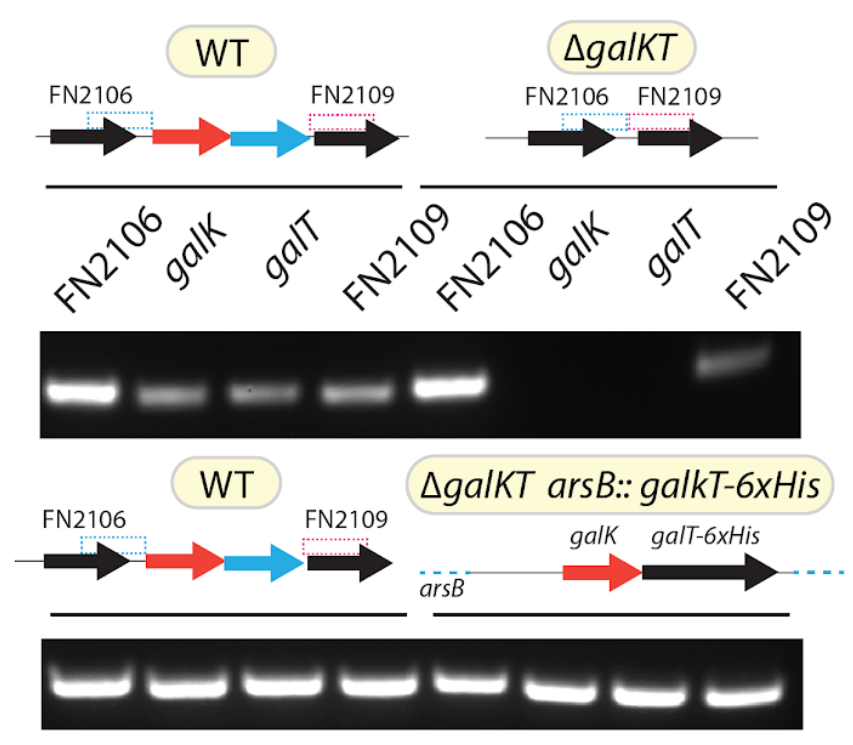

$\mathrm{D}$

$\mathrm{E}$
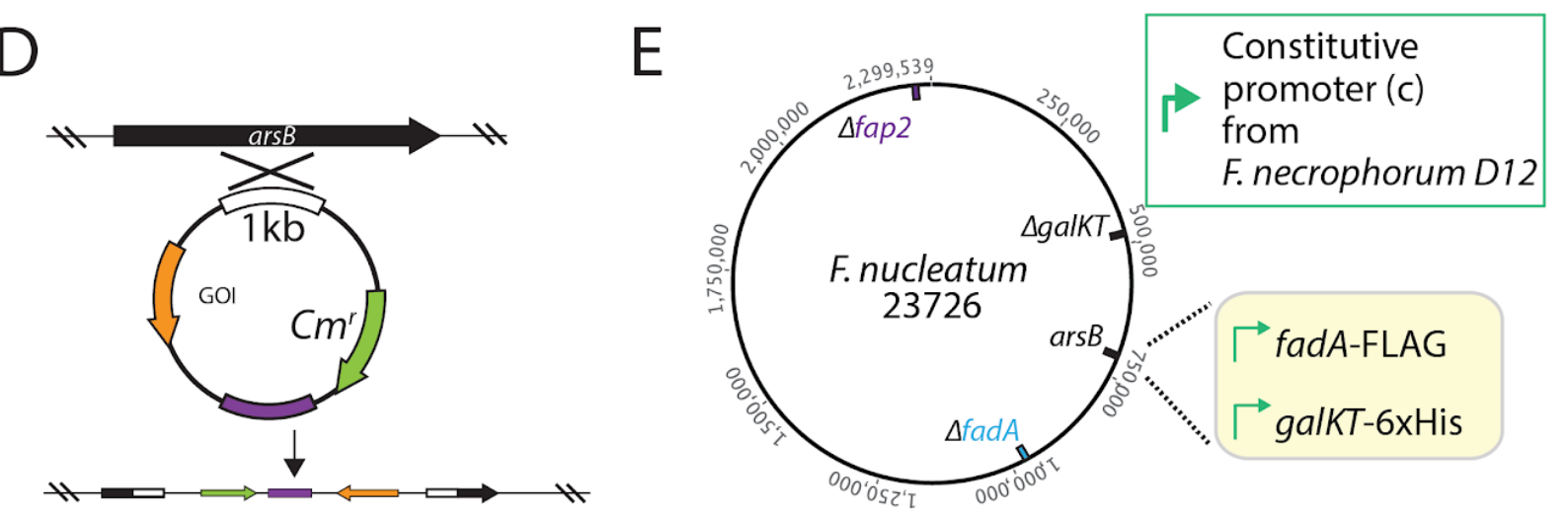

$\mathrm{F}$

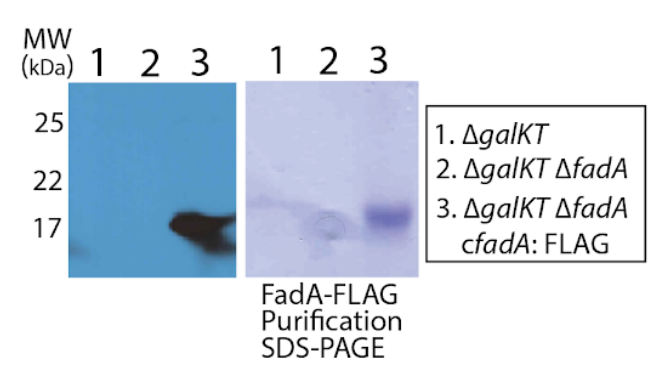

Fig. S6. Complementation of gene deletions at the static arsB gene site in $F$. nucleatum 23726. (A) pDJSVT20 plasmid created for complementing $\Delta$ galKT with galKT::6xHis. (B) RT-PCR of $\Delta g a l K T$ and $\Delta g a l K T$ galKT::6xHis and the two genes flanking the operon (FN2106, FN2109). (C) Western blot verification of galKT::6sHis complementation and constitutive expression of GalT::6xHis. (D) pDJSVT11 base vector depicted with target gene of interest (GOI) complementation and how it incorporates into the chromosome at arsB. (E) Potential sites for complementation of gene deletions used in this study. However, we did not complement the $\Delta$ fap2 strain due to the extreme difficulties of complementing large genes (12kb). (F) Complementation of $\triangle \mathrm{fad} A$ with fadA::FLAG and western blot verification of constitutive expression of FadA::FLAG. 
A

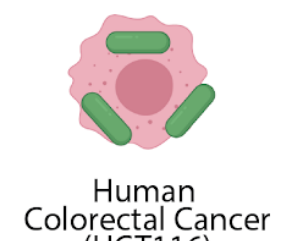

(HCT116)

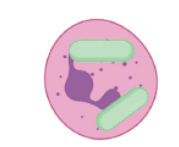

Mouse Neutrophils

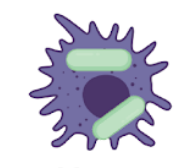

Mouse Macrophages

B

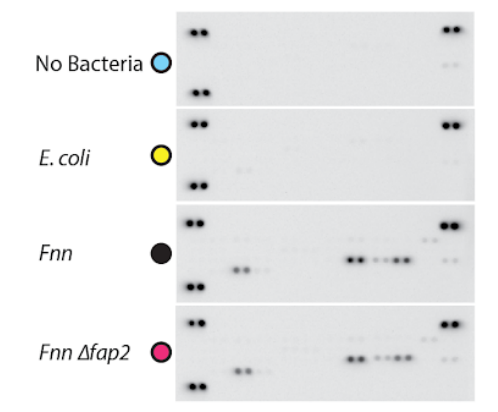

D

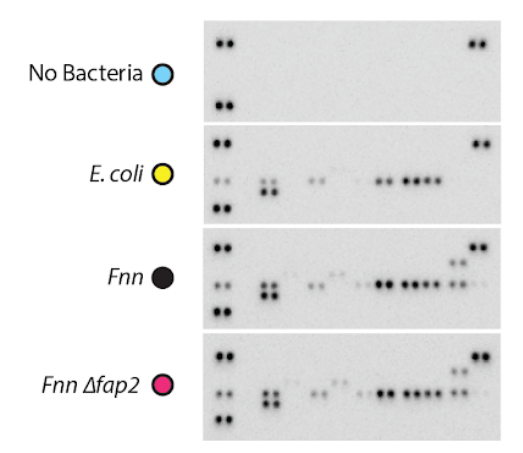

Human Cytokine Array Coordinates
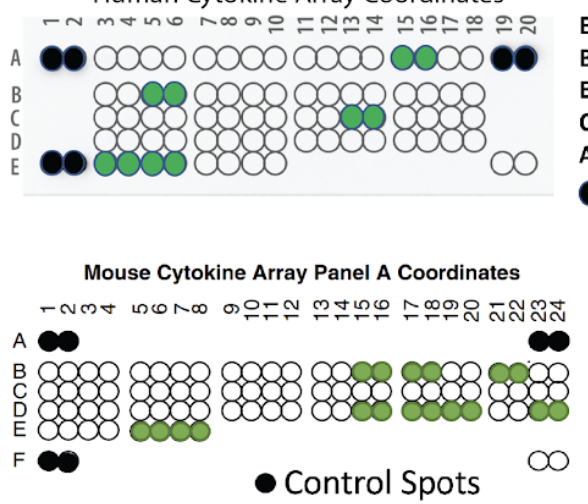

E3,4: MIF

B5,6: CXCL12/SDF-1

E5,6: Serpin E1/PAI-1

C13,14: IL-8

A15,16: CXCL1/GRO $\alpha$

- Control Spots

B15,16 IFN- $\boldsymbol{\gamma}$

B17,18 IL-1 $\alpha$

B21,22 IL-1ra

D15,16 MIP-1 $\alpha-$ CCL3

D17,18 MIP-1 $\beta$ - CCL4

D19,20 MIP-2 - CXCL2

D23,24 SDF-1 - CXCL12

E5,6 TNFa

E7,8 TREM-1

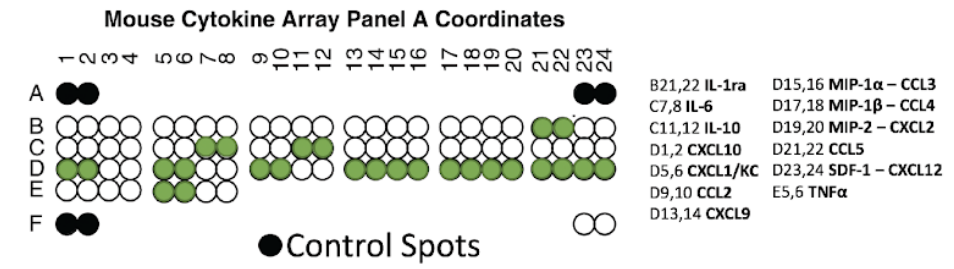

- Control Spots

Fig. S7. Human and mouse cytokine arrays to detect $F$. nucleatum induced immune signaling. (A) Cytokine array coordinates for human and mouse array with green dots representing spots analyzed due to detected expression. Gene names are shown to the right, and full coordinates for all spots can be found at R\&D Systems (R\&D: Proteome Profiler Human Cytokine Array (ARY005B), Proteome Profiler Mouse Cytokine Array Kit, Panel A (ARY006)). (B) Raw blots for mouse cytokines secreted by mouse neutrophils after infection with F. nucleatum 23726 at 50:1 MOI for four hours. (C) Quantitation of relative spot intensity compared to the control blot of uninfected neutrophils. (D) Raw blots for mouse cytokines secreted by mouse macrophages after infection with F. nucleatum 23726 at 50:1 MOI for four hours. (E) Quantitation of relative spot intensity compared to the control blot of uninfected macrophages. 
bioRxiv preprint doi: https://doi.org/10.1101/2020.01.15.907931; this version posted January 16,2020 . The copyright holder for this preprint (which was not certified by peer review) is the author/funder, who has granted bioRxiv a license to display the preprint in perpetuity. It is made available under aCC-BY-NC-ND 4.0 International license.

\section{Supplementary Table 1: Primers used in this study.}

\begin{tabular}{|c|c|c|}
\hline Primer Name & Sequence $\left(5^{\prime}\right.$ to $\left.3^{\prime}\right)$ & Description \\
\hline prDJSVT470 & $\begin{array}{l}\text { CAGCTCGGCGGCCGCGGTACCACGCGTcgagtga } \\
\text { aaaagtgtccctagcg }\end{array}$ & $\begin{array}{l}\text { Forward primer to clone fragment } \\
\text { A of construct pDJSVT1: Clones } \\
\text { catP out of pJIR750. Has Notl, } \\
\text { Kpnl, Mlul sites. }\end{array}$ \\
\hline prDJSVT471 & $\begin{array}{l}\text { CTAAAGTATATATGAGTAAACTTGGTCTGACAGca } \\
\text { aggtcttgtactaacctgtggttatg }\end{array}$ & $\begin{array}{l}\text { Reverse primer to clone fragment } \\
\text { A of construct pDJSVT1: Overlaps } \\
\text { with prDJSVT472: beginning of } \\
\text { pMB1 ori from pUC19. OLE-PCR. }\end{array}$ \\
\hline prDJSVT472 & ctgtcagaccaagtttactcatatatactttag & $\begin{array}{l}\text { Forward primer to clone fragment } \\
\text { B of construct pDJSVT1: pMB1 ori } \\
\text { from pUC19. Overlaps with } \\
\text { prDJSVT471: end of catP from } \\
\text { pJIR750. }\end{array}$ \\
\hline prDJSVT473 & $\begin{array}{l}\text { CTCGATGCGGCCGCCTCGAGccaggaaccgtaaaaag } \\
\text { gccgcgttg }\end{array}$ & $\begin{array}{l}\text { Reverse primer to clone fragment } \\
\text { B of construct pDJSVT1: pMB1 ori } \\
\text { from pUC19. Has Xhol and Notl } \\
\text { sites. }\end{array}$ \\
\hline prDJSVT7239 & $\begin{array}{l}\text { ctagaggtaccTGTTAATCCATTTGCTACTGTTATTGC } \\
\text { ATC }\end{array}$ & $\begin{array}{l}\text { Forward primer -1000bp upstream } \\
\text { of galKT in F. nuc } 23726 \text {. Has a } \\
\text { Kpnl site. Makes construct } \\
\text { pDJSVT13. }\end{array}$ \\
\hline prDJSVT730 & $\begin{array}{l}\text { GCCTGCTCCTCCACAAACTAATATAGACAAAAAT } \\
\text { TCCССTTCCAAAATAATATTGTAAC }\end{array}$ & $\begin{array}{l}\text { Reverse primer }-1 \text { bp upstream of } \\
\text { galKT in F. nuc } 23726 \text {. Overlaps } \\
\text { with prDJSVT731 for OLE-PCR. } \\
\text { Makes construct pDJSVT13. }\end{array}$ \\
\hline prDJSVT731 & GTCTATATTAGTTTGTGGAGGAGCAGGC & $\begin{array}{l}\text { Forward primer }+1 \text { bp downstream } \\
\text { of galKT in F. nuc } 23726 \text {. } \\
\text { Overlaps with prDJSVT730 for } \\
\text { OLE-PCR. } \\
\text { Makes construct pDJSVT13. }\end{array}$ \\
\hline prDJSVT732 & $\begin{array}{l}\text { gatcgtacgcgtAGCCTCTTATTTTAATCTTCATATCCA } \\
\text { TTTGG }\end{array}$ & $\begin{array}{l}\text { Reverse primer }+1000 \mathrm{bp} \\
\text { downstream of galKT in F. nuc } \\
23726 . \text { Has an Mlul site. } \\
\text { Makes construct pDJSVT13. }\end{array}$ \\
\hline prDJSVT743 & GGAGCTTTTGATGCTGGAATGGCAGCTC & $\begin{array}{l}\text { Forward confirmation primer }-1240 \\
\text { bp upstream of galK (FN2107) in } \\
\text { F. nuc } 23726 \text {. }\end{array}$ \\
\hline prDJSVT744 & GAAGAGAAGATGGAAAATGGTTGTTTTATGATG & $\begin{array}{l}\text { Reverse confirmation primer } \\
+1240 \text { bp downstream of galT } \\
\text { (FN2108) in F. nuc } 23726\end{array}$ \\
\hline
\end{tabular}


bioRxiv preprint doi: https://doi.org/10.1101/2020.01.15.907931; this version posted January 16, 2020. The copyright holder for this preprint (which was not certified by peer review) is the author/funder, who has granted bioRxiv a license to display the preprint in perpetuity. It is made available under aCC-BY-NC-ND 4.0 International license.

\begin{tabular}{|c|c|c|}
\hline prDJSVT863 & CATTAGAAATGGCAGGAACAACTTTTGATAAG & $\begin{array}{l}\text { Forward primer - } 250 \text { galKT F. nuc. } \\
23726 \text { start for sequencing }\end{array}$ \\
\hline prDJSVT864 & САСТTТСТССАACCAAAGAGAAAGCAGC & $\begin{array}{l}\text { Reverse primer }+250 \text { galKT } F . \\
\text { nuc. } 23726 \text { start for sequencing }\end{array}$ \\
\hline prDJSVT753 & $\begin{array}{l}\text { ctgactgcggccgcTTTTAAATCCTTTCTTTTTCACTAA } \\
\text { TCTTCTTTTTC }\end{array}$ & $\begin{array}{l}\text { Forward primer to put F. nec D12 } \\
\text { Promoter (A0A017H3W9: } \\
\text { Pseudouridine synthase) on } \\
\text { FLAG:galK. Has a Notl site. } \\
\text { Makes construct pDJSVT7. }\end{array}$ \\
\hline prDJSVT754 & $\begin{array}{l}\text { catcatcatctttataatccatTCCAAACTCCTTATCTTTTTC } \\
\text { TTTTTTAGATG }\end{array}$ & $\begin{array}{l}\text { Reverse primer to put F. nec D12 } \\
\text { Promoter (A0A017H3W9: } \\
\text { Pseudouridine synthase) on } \\
\text { FLAG:galK. Complementary with } \\
\text { prDJSVT745 for OLE-PCR. } \\
\text { Makes construct pDJSVT7. }\end{array}$ \\
\hline prDJSVT745 & $\begin{array}{l}\text { ATGGATTATAAAGATGATGATGATAAATTAGAAAA } \\
\text { TTTAATAAAAGACTTTAAAGAAATT }\end{array}$ & $\begin{array}{l}\text { Forward primer to clone galK out } \\
\text { of } F . \text { nuc } 23726.5^{\prime} \text { end has FLAG } \\
\text { tag and is complementary to } 3^{\prime} \text { of } \\
\text { prDJSVT754. Makes construct } \\
\text { pDJSVT7. }\end{array}$ \\
\hline prDJSVT746 & TTATTTCAССТTTССТGСТССАТСТС & $\begin{array}{l}\text { Reverse primer to clone galK out } \\
\text { of } F . \text { nuc } 23726 \text { and into } \\
\text { pDJSVT1. Is compatible for } \\
\text { OLE-PCR with prDJSVT } 747 \text { to } \\
\text { add a catP terminator. Makes } \\
\text { construct pDJSVT7. }\end{array}$ \\
\hline prDJSVT747 & $\begin{array}{l}\text { GAGATGGAGCAGGAAAGGTGAAATAActtcaggtttgt } \\
\text { ctgtaactaaaaac }\end{array}$ & $\begin{array}{l}\text { Forward primer to add catP } \\
\text { terminator to galK. OLE with } \\
\text { prDJSVT746. Makes construct } \\
\text { pDJSVT7. }\end{array}$ \\
\hline prDJSVT748 & cgtctgCTCGAGcaaggtctttgtactaacctgtggttatg & $\begin{array}{l}\text { Reverse primer to add catP } \\
\text { terminator to galK. Has an Xhol. } \\
\text { Makes construct pDJSVT7. }\end{array}$ \\
\hline prDJSVT776 & $\begin{array}{l}\text { ctagaggtaccGAAACGATACATAGTAGATTAGAAAT } \\
\text { ATTGCTCTTACTG }\end{array}$ & $\begin{array}{l}\text { Forward primer to insert central } \\
1000 \text { bp of } F \text {. nuc } 23726 \text { arsB } \\
\text { (AVQ22750.1) into pDJSVT1. Has } \\
\text { a Kpnl site. Makes construct } \\
\text { pDJSVT11. }\end{array}$ \\
\hline prDJSVT777 & $\begin{array}{l}\text { gatcgtacgcgtGTTGCAGAACCTATCATTGTGATACT } \\
\text { TCCG }\end{array}$ & $\begin{array}{l}\text { Reverse primer to insert central } \\
1000 \text { bp of } F \text {. nuc } 23726 \text { arsB } \\
\text { (AVQ22750.1) into pDJSVT1. Has } \\
\text { an Mlul site. Makes construct } \\
\text { pDJSVT11. }\end{array}$ \\
\hline prDJSVT791 & gagctagaggtaccGTAGTGATAAAGATGCTGGAAAA & Forward primer -750bp upstream \\
\hline
\end{tabular}


bioRxiv preprint doi: https://doi.org/10.1101/2020.01.15.907931; this version posted January 16,2020 . The copyright holder for this preprint (which was not certified by peer review) is the author/funder, who has granted bioRxiv a license to display the preprint in perpetuity. It is made available under aCC-BY-NC-ND 4.0 International license.

\begin{tabular}{|c|c|c|}
\hline & AATACTATTCC & $\begin{array}{l}\text { of fap2 in F. nuc } 23726 . \text { Has a } \\
\text { Kpnl site. Makes construct } \\
\text { pDJSVT14. }\end{array}$ \\
\hline prDJSVT792 & $\begin{array}{l}\text { CTCTTAATTATGTTAATTGTAAATTTAAGCCTTTTT } \\
\text { AAtataatttccccctttttattttatattttaaattatactttttaaatatag }\end{array}$ & $\begin{array}{l}\text { Reverse primer -1bp upstream of } \\
\text { fap2 in F. nuc } 23726 \text {. Overlaps } \\
\text { with prDJSVT793 for OLE-PCR. } \\
\text { Makes construct pDJSVT14. }\end{array}$ \\
\hline prDJSVT793 & $\begin{array}{l}\text { TTAAAAAGGCTTAAATTTACAATTAACATAATTAA } \\
\text { GAGAATTTTTTGAG }\end{array}$ & $\begin{array}{l}\text { Forward primer }+1 \text { bp downstream } \\
\text { of fap } 2 \text { in F. nuc } 23726 \text {. Overlaps } \\
\text { with prDJSVT792 for OLE-PCR. } \\
\text { Makes construct pDJSVT14. }\end{array}$ \\
\hline prDJSVT794 & $\begin{array}{l}\text { cgtgatcgtacgcgtGCTTGTGTAGAATCATTTCCTGTT } \\
\text { AACAAAC }\end{array}$ & $\begin{array}{l}\text { Reverse primer }+750 \mathrm{bp} \\
\text { downstream of fap2 in F. nuc } \\
23726 . \text { Has an Mlul site. } \\
\text { Makes construct pDJSVT14. }\end{array}$ \\
\hline prDJSVT795 & gaagatattccagaaaaaatgatagtagaaaatac & $\begin{array}{l}\text { Forward confirmation primer }-1000 \\
\text { bp upstream of fap2 in F. nuc } \\
23726 .\end{array}$ \\
\hline prDJSVT796 & ggaatttcatctccactactaggagtag & $\begin{array}{l}\text { Reverse confirmation primer } \\
+1000 \text { bp downstream of fap } 2 \text { in } F \text {. } \\
\text { nuc } 23726\end{array}$ \\
\hline prDJSVT859 & GGAGCAACTCAACCTCTTGCAACTTTATG & $\begin{array}{l}\text { Forward primer -250 fap2 F. nuc. } \\
23726 \text { start for sequencing }\end{array}$ \\
\hline prDJSVT860 & CAGGTCATTCCTCATTATAATCTCCCCTTTTTTG & $\begin{array}{l}\text { Reverse primer }+250 \text { fap } 2 \text { F. nuc. } \\
23726 \text { start for sequencing }\end{array}$ \\
\hline prDJSVT582 & $\begin{array}{l}\text { ctagaggtaccGCAAAAGAAGCTCAATATACAAATTA } \\
\text { TGAAATTG }\end{array}$ & $\begin{array}{l}\text { Forward primer -750bp upstream } \\
\text { of fadA in F. nuc } 23726 \text {. Has a } \\
\text { Kpnl site. Makes construct } \\
\text { pDJSVT15. }\end{array}$ \\
\hline prDJSVT565 & $\begin{array}{l}\text { CTAGCATTTTTTCAAAATTTATTTTGTTACCTCCC } \\
\text { AAATTAAATTATAATAAATTATTTC }\end{array}$ & $\begin{array}{l}\text { Reverse primer -1bp upstream of } \\
\text { fadA in F. nuc } 23726 \text {. Overlaps } \\
\text { with prDJSVT566 for OLE-PCR. } \\
\text { Makes construct pDJSVT15. }\end{array}$ \\
\hline prDJSVT566 & TAAATTTTGAAAAAATGCTAGCATGAAATAAAACC & $\begin{array}{l}\text { Forward primer }+1 \text { bp downstream } \\
\text { of fadA in F. nuc } 23726 \text {. Overlaps } \\
\text { with prDJSVT565 for OLE-PCR. } \\
\text { Makes construct pDJSVT15. }\end{array}$ \\
\hline prDJSVT567 & $\begin{array}{l}\text { gatcgtacgcgtCAGCATAATCAAGTCCTGTATTGGCA } \\
\text { TTATTTAAG }\end{array}$ & $\begin{array}{l}\text { Reverse primer }+750 \mathrm{bp} \\
\text { downstream of fadA in F. nuc } \\
23726 . \text { Has an Mlul site. } \\
\text { Makes construct pDJSVT15. }\end{array}$ \\
\hline
\end{tabular}


bioRxiv preprint doi: https://doi.org/10.1101/2020.01.15.907931; this version posted January 16, 2020. The copyright holder for this preprint (which was not certified by peer review) is the author/funder, who has granted bioRxiv a license to display the preprint in perpetuity. It is made available under aCC-BY-NC-ND 4.0 International license.

\begin{tabular}{|c|c|c|}
\hline prDJSVT568 & $\begin{array}{l}\text { CAAATACATAAACAAATACTTAACATAAGTTTACT } \\
\text { ATG }\end{array}$ & $\begin{array}{l}\text { Forward confirmation primer }-1000 \\
\text { bp upstream of fadA in F. nuc } \\
23726 .\end{array}$ \\
\hline prDJSVT569 & $\begin{array}{l}\text { CAAATACATAAACAAATACTTAACATAAGTTTACT } \\
\text { ATG }\end{array}$ & $\begin{array}{l}\text { Reverse confirmation primer }-1000 \\
\text { bp upstream of fadA in F. nuc } \\
23726 .\end{array}$ \\
\hline prDJSVT867 & $\begin{array}{l}\text { GAGGCAAGAGAAACTATACTTGCAGATGTTAAAA } \\
\text { G }\end{array}$ & $\begin{array}{l}\text { Forward primer -250 fadA F. nuc. } \\
23726 \text { start for sequencing }\end{array}$ \\
\hline prDJSVT858 & GCTACAACTGTAATTACAACTGCATAAAACACTC & $\begin{array}{l}\text { Reverse primer }+250 \text { fadA F. nuc. } \\
23726 \text { start for sequencing }\end{array}$ \\
\hline prDJSVT576 & $\begin{array}{l}\text { ctagaggtaccCCAATATTTGCAATAATATTAGCAAG } \\
\text { GTTAC }\end{array}$ & $\begin{array}{l}\text { Forward primer -750bp upstream } \\
\text { of } c b p F \text { in F. nuc } 23726 \text {. Has a } \\
\text { Kpnl site. Makes construct } \\
\text { pDJSVT16. }\end{array}$ \\
\hline prDJSVT577 & $\begin{array}{l}\text { GATTAGAGGTGCAGTTTAAATTTTACAAAATTCTC } \\
\text { TCCTAATAAAATATTTATATAATC }\end{array}$ & $\begin{array}{l}\text { Reverse primer }-1 \text { bp upstream of } \\
c b p F \text { in F. nuc } 23726 \text {. Overlaps } \\
\text { with prDJSVT578 for OLE-PCR. } \\
\text { Makes construct pDJSVT16. }\end{array}$ \\
\hline prDJSVT578 & GTAAAATTTAAACTGCACCTCTAATCTTATG & $\begin{array}{l}\text { Forward primer }+1 \text { bp downstream } \\
\text { of } c b p F \text { in F. nuc } 23726 \text {. Overlaps } \\
\text { with prDJSVT577 for OLE-PCR. } \\
\text { Makes construct pDJSVT16. }\end{array}$ \\
\hline prDJSVT579 & $\begin{array}{l}\text { gatcgtacgcgtGGAGAACAGGAAGTATTAAACTCATT } \\
\text { TTCTTTG }\end{array}$ & $\begin{array}{l}\text { Reverse primer }+750 b p \\
\text { downstream of } c b p F \text { in } F . \text { nuc } \\
\text { 23726. Has an Mlul site. } \\
\text { Makes construct pDJSVT16. }\end{array}$ \\
\hline prDJSVT580 & CAAGATTATTTAGTTTACATGTTCCATTTG & $\begin{array}{l}\text { Forward confirmation primer }-1000 \\
\text { bp upstream of } c b p F \text { in F. nuc } \\
23726 \text {. }\end{array}$ \\
\hline prDJSVT581 & CAAAGAACTTAATAAGATGGGTAAAAGTATTATTC & $\begin{array}{l}\text { Reverse confirmation primer }-1000 \\
\text { bp upstream of } c b p F \text { in F. nuc } \\
23726 \text {. }\end{array}$ \\
\hline prDJSVT940 & $\begin{array}{l}\text { gagctagaggtaccAGCTCTAAAAGCATAAATAGACAA } \\
\text { GATTAGTAATAATAAAG }\end{array}$ & $\begin{array}{l}\text { Forward primer }-750 b p \text { upstream } \\
\text { of } f v c B \text { in } F . \text { nuc } 23726 . \text { Has a } \\
\text { Kpnl site. Makes construct } \\
\text { pDJSVT17. }\end{array}$ \\
\hline prDJSVT941 & $\begin{array}{l}\text { GATTTTTTAAATCTGCAATTGGCTTTTTTTATTCAT } \\
\text { TAAAAATACCTCCTTAAGTAAAATATTATTTTTTTA } \\
\text { TATGTTTC }\end{array}$ & $\begin{array}{l}\text { Reverse primer }-1 \text { bp upstream of } \\
f v c B \text { in F. nuc } 23726 \text {. Overlaps } \\
\text { with prDJSVT942 for OLE-PCR. } \\
\text { Makes construct pDJSVT17. }\end{array}$ \\
\hline prDJSVT942 & $\begin{array}{l}\text { AATGAATAAAAAAAGCCAATTGCAGATTTAAAAAA } \\
\text { TC }\end{array}$ & $\begin{array}{l}\text { Forward primer }+1 \text { bp downstream } \\
\text { of } f v c B \text { in F. nuc } 23726 \text {. Overlaps }\end{array}$ \\
\hline
\end{tabular}


bioRxiv preprint doi: https://doi.org/10.1101/2020.01.15.907931; this version posted January 16,2020 . The copyright holder for this preprint (which was not certified by peer review) is the author/funder, who has granted bioRxiv a license to display the preprint in perpetuity. It is made available under aCC-BY-NC-ND 4.0 International license.

\begin{tabular}{|c|c|c|}
\hline & & $\begin{array}{l}\text { with prDJSVT941 for OLE-PCR. } \\
\text { Makes construct pDJSVT17. }\end{array}$ \\
\hline prDJSVT943 & $\begin{array}{l}\text { cgtgatcgtacgcgtGATGGTAAAGCTGTTATTTTAAGT } \\
\text { GAATTAGAC }\end{array}$ & $\begin{array}{l}\text { Reverse primer }+750 \mathrm{bp} \\
\text { downstream of } f v c B \text { in } F . \text { nuc } \\
23726 . \text { Has an Mlul site. } \\
\text { Makes construct pDJSVT17. }\end{array}$ \\
\hline prDJSVT944 & CCAAACTTTTTGGCTAGTCCCTACCTC & $\begin{array}{l}\text { Forward confirmation primer }-1000 \\
\text { bp upstream of } f v c B \text { in } F . \text { nuc } \\
23726 \text {. }\end{array}$ \\
\hline prDJSVT945 & $\begin{array}{l}\text { GTTGAAAAAAATGGTTTTTCTGTTGTAAGAGATTT } \\
\text { TG }\end{array}$ & $\begin{array}{l}\text { Reverse confirmation primer }-1000 \\
\text { bp upstream of } f v c B \text { in } F . \text { nuc } \\
23726 \text {. }\end{array}$ \\
\hline prDJSVT946 & $\begin{array}{l}\text { CTTCTATCATAGCTTCTCCTAATTTTATTTTATCTC } \\
\text { TC }\end{array}$ & $\begin{array}{l}\text { Forward primer }-250 \text { fvcB F. nuc. } \\
23726 \text { start for sequencing }\end{array}$ \\
\hline prDJSVT947 & GAAACTAGCTTTAATATTGCGACAAAGTAAGAAC & $\begin{array}{l}\text { Reverse primer }+250 \text { fvcB F. nuc. } \\
23726 \text { start for sequencing }\end{array}$ \\
\hline prDJSVT948 & $\begin{array}{l}\text { gagctagaggtaccCCAATAGTCTTTACTTAACACATA } \\
\text { ACCTAATTC }\end{array}$ & $\begin{array}{l}\text { Forward primer -750bp upstream } \\
\text { of } f v c C \text { in F. nuc } 23726 . \text { Has a } \\
\text { Kpnl site. Makes construct } \\
\text { pDJSVT18. }\end{array}$ \\
\hline prDJSVT949 & $\begin{array}{l}\text { CCCTAATCTTTAAAGAGTGCAGTTTTTTTCATTAAAA } \\
\text { TACCTCCTTAAGTAAAACATTATTTTTTATATG }\end{array}$ & $\begin{array}{l}\text { Reverse primer - } 1 \text { bp upstream of } \\
f v c C \text { in F. nuc } 23726 \text {. Overlaps } \\
\text { with prDJSVT950 for OLE-PCR. } \\
\text { Makes construct pDJSVT18. }\end{array}$ \\
\hline prDJSVT950 & AATGAAAAAACTGCACTCTTAAAGATTAGGG & $\begin{array}{l}\text { Forward primer }+1 \mathrm{bp} \text { downstream } \\
\text { of } f v c C \text { in F. nuc } 23726 \text {. Overlaps } \\
\text { with prDJSVT949 for OLE-PCR. } \\
\text { Makes construct pDJSVT18. }\end{array}$ \\
\hline prDJSVT951 & $\begin{array}{l}\text { cgtgatcgtacgcgtGTATTAAAAGATGAAGTAATGGAG } \\
\text { GAGTAATTATTATG }\end{array}$ & $\begin{array}{l}\text { Reverse primer }+750 \mathrm{bp} \\
\text { downstream of } f v c C \text { in F. nuc } \\
23726 . \text { Has an Mlul site. } \\
\text { Makes construct pDJSVT18. }\end{array}$ \\
\hline prDJSVT952 & СTTTTGATTATTCССССТСАTTTTAАСТССТАTC & $\begin{array}{l}\text { Forward confirmation primer }-1000 \\
\text { bp upstream of } f v c C \text { in F. nuc } \\
23726 \text {. }\end{array}$ \\
\hline prDJSVT953 & $\begin{array}{l}\text { GGAATTATAGCAACAGATAGAAGAAAAAGACATA } \\
\text { TAAG }\end{array}$ & $\begin{array}{l}\text { Reverse confirmation primer }-1000 \\
\text { bp upstream of } f v c C \text { in } F . \text { nuc } \\
23726 \text {. }\end{array}$ \\
\hline prDJSVT954 & GAACTAATTTCATAGGAGTAAATTTAAGTCCATC & $\begin{array}{l}\text { Forward primer }-250 \text { fvcC F. nuc. } \\
23726 \text { start for sequencing }\end{array}$ \\
\hline prDJSVT955 & CAGAAAAAAATTATAAAGTAGAAATGAACTGAAA & Reverse primer +250 fvcC F. nuc. \\
\hline
\end{tabular}


bioRxiv preprint doi: https://doi.org/10.1101/2020.01.15.907931; this version posted January 16,2020 . The copyright holder for this preprint (which was not certified by peer review) is the author/funder, who has granted bioRxiv a license to display the preprint in perpetuity. It is made available under aCC-BY-NC-ND 4.0 International license.

\begin{tabular}{|c|c|c|}
\hline & TG & 23726 start for sequencing \\
\hline prDJSVT876 & $\begin{array}{l}\text { gagctagaggtaccGTAAATCATAATAATCAGGTGGAA } \\
\text { CTTTTAAAGAAG }\end{array}$ & $\begin{array}{l}\text { Forward primer }-750 \mathrm{bp} \text { upstream } \\
\text { of } f v c D \text { in } F . n u c 23726 \text {. Has a } \\
\text { Kpnl site. Makes construct } \\
\text { pDJSVT19. }\end{array}$ \\
\hline prDJSVT877 & $\begin{array}{l}\text { TTCTTCTTCTTTTTTTCTACACGCTAAAAAAACTCC } \\
\text { CCССTAAATAAAATTTTATTTTTAA }\end{array}$ & $\begin{array}{l}\text { Reverse primer }-1 \mathrm{bp} \text { upstream of } \\
f v c D \text { in } F . n u c \text { } 23726 \text {. Overlaps } \\
\text { with prDJSVT878 for OLE-PCR. } \\
\text { Makes construct pDJSVT19. }\end{array}$ \\
\hline prDJSVT878 & AGCGTGTAGAAAAAAGAAGAAGAAAATAAAATG & $\begin{array}{l}\text { Forward primer }+1 \text { bp downstream } \\
\text { of } f v c D \text { in } F . n u c ~ 23726 \text {. Overlaps } \\
\text { with prDJSVT877 for OLE-PCR. } \\
\text { Makes construct pDJSVT19. }\end{array}$ \\
\hline prDJSVT879 & $\begin{array}{l}\text { cgtgatcgtacgcgtGGAAGATATGAAGAAGAAAATGAT } \\
\text { TTACCTTGGG }\end{array}$ & $\begin{array}{l}\text { Reverse primer }+750 \mathrm{bp} \\
\text { downstream of } f v c D \text { in } F . \text { nuc } \\
23726 . \text { Has an Mlul site. } \\
\text { Makes construct pDJSVT19. }\end{array}$ \\
\hline prDJSVT880 & GGGTTGCTATGGAGAATGTAATTTCTGTGC & $\begin{array}{l}\text { Forward confirmation primer }-1000 \\
\text { bp upstream of } f v c D \text { in F. nuc } \\
23726 \text {. }\end{array}$ \\
\hline prDJSVT881 & $\begin{array}{l}\text { GTTATATTGGTTTGCCAGAGATGAAAAAATTAAA } \\
\text { AAAG }\end{array}$ & $\begin{array}{l}\text { Reverse confirmation primer }-1000 \\
\text { bp upstream of } f v c D \text { in } F . n u c \\
23726 \text {. }\end{array}$ \\
\hline prDJSVT882 & GGAAAAAAGCAAAAACAAAAAGATATAGTTACTG & $\begin{array}{l}\text { Forward primer }-250 \text { fvcD F. nuc. } \\
23726 \text { start for sequencing }\end{array}$ \\
\hline prDJSVT883 & $\begin{array}{l}\text { GATATTGGAGCTCTTGTTTGGTATGCTCATATTAT } \\
\text { TG }\end{array}$ & $\begin{array}{l}\text { Reverse primer }+250 f v c D F . \text { nuc. } \\
23726 \text { start for sequencing }\end{array}$ \\
\hline \multicolumn{3}{|c|}{ Beginning of RT-PCR primers for gene KO confirmation } \\
\hline prDJSVT966 & CAACTGAATTTATTGCAGGTATGAGTAAAGGTG & $\begin{array}{l}\text { Forward Primer for RT-PCR of } \\
\text { FN2106, gene upstream of galK }\end{array}$ \\
\hline prDJSVT967 & CAAAAGTTGTTCCTGCCATTTCTAATGTTAC & $\begin{array}{l}\text { Reverse Primer for RT-PCR of } \\
\text { FN2106, gene upstream of galK }\end{array}$ \\
\hline prDJSVT968 & GAGCGACTCATGCAGTTACTGAAAATG & $\begin{array}{l}\text { Forward Primer for RT-PCR of } \\
\text { FN2107, galK }\end{array}$ \\
\hline prDJSVT969 & CATAGTCATTTTCAACTATGCTTACAGTACAAC & $\begin{array}{l}\text { Reverse Primer for RT-PCR of } \\
\text { FN2017, galK }\end{array}$ \\
\hline prDJSVT970 & GTTATGGGACTTGCAGTTTTACCAGG & $\begin{array}{l}\text { Forward Primer for RT-PCR of } \\
\text { FN2108, galT }\end{array}$ \\
\hline prDJSVT971 & СТTTTAАATAСТССТGСАТСТTСАAGАACTC & Reverse Primer for RT-PCR of \\
\hline
\end{tabular}


bioRxiv preprint doi: https://doi.org/10.1101/2020.01.15.907931; this version posted January 16, 2020. The copyright holder for this preprint (which was not certified by peer review) is the author/funder, who has granted bioRxiv a license to display the preprint in perpetuity. It is made available under aCC-BY-NC-ND 4.0 International license.

\begin{tabular}{|l|l|l|}
\hline & & FN2108, galT \\
\hline prDJSVT972 & GCTTTAAATAGATTAAGAAATGGTGGAGATAGCC & $\begin{array}{l}\text { Forward Primer for RT-PCR of } \\
\text { FN2109, gene downstream of galT }\end{array}$ \\
\hline prDJSVT973 & GCCAGTTCCAAGCAGTTTCAATAATTTGTTC & $\begin{array}{l}\text { Forward Primer for RT-PCR of } \\
\text { FN2109, gene downstream of galT }\end{array}$ \\
\hline prDJSVT845 & GTTGAAAACACAAATATAGAAGAAAATGTATTG & $\begin{array}{l}\text { Forward Primer for RT-PCR of } \\
\text { FN0263, gene upstream of fadA }\end{array}$ \\
\hline prDJSVT846 & CTAGTGCCGGATGAATTTCTGTCAC & $\begin{array}{l}\text { Reverse Primer for RT-PCR of } \\
\text { FN0263, gene upstream of fadA }\end{array}$ \\
\hline prDJSVT847 & GTAGGTGAATTACAAGCATTAGATGCTG & $\begin{array}{l}\text { Forward Primer for RT-PCR of } \\
\text { FN0264, fadA }\end{array}$ \\
\hline prDJSVT848 & CCATTTCAGATTCTAATTTCTTTAAAGCATC & $\begin{array}{l}\text { Reverse Primer for RT-PCR of } \\
\text { FN0264, fadA }\end{array}$ \\
\hline prDJSVT849 & CCCTTTAACAGATTCATTGGTAATCTCAG & $\begin{array}{l}\text { Forward Primer for RT-PCR of } \\
\text { FN0265, gene downstream of } \\
\text { fadA }\end{array}$ \\
\hline prDJSVT850 & GGCATTATTTAAGAATTCTATTGCTACTCC & $\begin{array}{l}\text { Reverse Primer for RT-PCR of } \\
\text { FN0265, gene downstream of } \\
\text { fadA }\end{array}$ \\
\hline prDJSVI854 & CATTCCTATTCCCTTTTCGCCTGATAAAG & $\begin{array}{l}\text { Forward Primer for RT-PCR of } \\
\text { FN1448, gene upstream of fap2 }\end{array}$ \\
\hline prDJSVT851 & GGAGTAGCTGATGGAAAATTCAATATTCAAG & $\begin{array}{l}\text { Reverse Primer for RT-PCR of } \\
\text { FN1448, gene upstream of fap2 }\end{array}$ \\
\hline FN1449, fap2
\end{tabular}


bioRxiv preprint doi: https://doi.org/10.1101/2020.01.15.907931; this version posted January 16,2020 . The copyright holder for this preprint (which was not certified by peer review) is the author/funder, who has granted bioRxiv a license to display the preprint in perpetuity. It is made available under aCC-BY-NC-ND 4.0 International license.

\section{Supplementary Table 2: Plasmids used in this study.}

\begin{tabular}{|c|c|c|}
\hline Plasmid Name & Description & Source or Reference \\
\hline pUC19 & High copy E. coli plasmid & {$[1]$} \\
\hline pJIR750 & $\begin{array}{l}\text { Base C. perfringens-E. coli shuttle } \\
\text { vector to make F. nucleatum } \\
\text { shuttle vectors. }\left(\mathrm{Cm}^{r} \mathrm{Tm}^{r}\right)\end{array}$ & [2] \\
\hline pDJSVT1 & $\begin{array}{l}\text { Base vector for creating all } F \text {. } \\
\text { nucleatum gene deletion plasmids. } \\
\left(\mathrm{Cm}^{r} \mathrm{Tm}^{r}\right)\end{array}$ & This study \\
\hline pDJSVT7 & $\begin{array}{l}\text { Vector containing a FLAG:galK } \\
\text { gene to make double crossover } \\
\text { gene deletions in a } \Delta \text { galKT } \\
\text { background. }\left(\mathrm{Cm}^{r} \mathrm{Tm}^{r}\right)\end{array}$ & This study \\
\hline pDJSVT11 & $\begin{array}{l}\text { Chromosomal complementation } \\
\text { vector for F. nucleatum } 23726 \text {. } \\
\text { Incorporates a plasmid within the } \\
\text { chromosomal ars } B \text { gene using } \\
\text { homologous recombination. } \\
\left(\mathrm{Cm}^{r} \mathrm{Tm}^{r}\right)\end{array}$ & This study \\
\hline pDJSVT13 & $\begin{array}{l}\text { galKT gene deletion vector for } F \\
\text { nucleatum } 23726 .\left(\mathrm{Cm}^{\mathrm{r}} \mathrm{Tm}^{\mathrm{r}}\right)\end{array}$ & This study \\
\hline pDJSVT14 & $\begin{array}{l}\text { fap2 gene deletion vector for } F \\
\text { nucleatum } 23726\left(\mathrm{Cm}^{\mathrm{r}} \mathrm{Tm}^{\mathrm{r}}\right)\end{array}$ & This study \\
\hline pDJSVT15 & $\begin{array}{l}\text { fadA gene deletion vector for } F \\
\text { nucleatum } 23726\left(\mathrm{Cm}^{r} \mathrm{Tm}^{r}\right)\end{array}$ & This study \\
\hline pDJSVT16 & $\begin{array}{l}\text { cbpF gene deletion vector for } F \text {. } \\
\text { nucleatum } 23726\left(\mathrm{Cm}^{r} \mathrm{Tm}^{r}\right)\end{array}$ & This study \\
\hline pDJSVT17 & $\begin{array}{l}\text { fvcB gene deletion vector for } F \\
\text { nucleatum } 23726\left(\mathrm{Cm}^{r} \mathrm{Tm}^{r}\right)\end{array}$ & This study \\
\hline pDJSVT18 & $\begin{array}{l}\text { fvcC gene deletion vector for } F \\
\text { nucleatum } 23726\left(\mathrm{Cm}^{r} \mathrm{Tm}^{r}\right)\end{array}$ & This study \\
\hline pDJSVT19 & $\begin{array}{l}\text { fvcD gene deletion vector for } F \\
\text { nucleatum } 23726\left(\mathrm{Cm}^{r} \mathrm{Tm}^{r}\right)\end{array}$ & This study \\
\hline pDJSVT20 & $\begin{array}{l}\text { Chromosomal complementation } \\
\text { vector for galKT::6xHis in F. } \\
\text { nucleatum } 23726 \text {. Incorporates a } \\
\text { plasmid within the chromosomal } \\
\text { arsB gene expressing } \\
\text { galKT::6xHis to complement strain } \\
\text { DJSVT02 ( } \Delta \text { galKT) }\end{array}$ & This study \\
\hline
\end{tabular}


bioRxiv preprint doi: https://doi.org/10.1101/2020.01.15.907931; this version posted January 16, 2020. The copyright holder for this preprint (which was not certified by peer review) is the author/funder, who has granted bioRxiv a license to display the preprint in perpetuity. It is made available under aCC-BY-NC-ND 4.0 International license.

$\mathrm{Cm}^{r}$, Chloramphenicol resistance

$\mathrm{Tm}^{r}$, Thiamphenicol resistance

1. Yanisch-Perron, C., Vieira, J. and Messing, J. (1985). Gene. 33, 103-119.

2. Bannam TL, Rood Jl. Clostridium perfringens-Escherichia coli shuttle vectors that carry single antibiotic resistance determinants. Plasmid. 1993;29: 233-235. 
bioRxiv preprint doi: https://doi.org/10.1101/2020.01.15.907931; this version posted January 16, 2020. The copyright holder for this preprint (which was not certified by peer review) is the author/funder, who has granted bioRxiv a license to display the preprint in perpetuity. It is made available under aCC-BY-NC-ND 4.0 International license.

\section{Supplementary Table 3: Bacterial strains used in this study.}

\begin{tabular}{|c|c|c|c|}
\hline Strain & $\begin{array}{l}\text { Bacterial } \\
\text { Species }\end{array}$ & Genotype and Characteristics & $\begin{array}{l}\text { Source or } \\
\text { Reference }\end{array}$ \\
\hline Top10 & E. coli & $\begin{array}{l}m c r A, \Delta(m r r-h s d R M S-m c r B C), \text { Phi80(del)M15, } \\
\Delta l a c X 74, \text { deoR, recA1, araD139, } \\
\Delta(\text { ara-leu }) 7697, \text { galU, galK, rpsL(SmR), } \\
\text { endA1, nupG }\end{array}$ & Invitrogen \\
\hline $\begin{array}{l}\text { F. nucleatum subsp. } \\
\text { nucleatum ATCC } 23726\end{array}$ & F. nucleatum & Wild Type & ATCC, $[1-4]$ \\
\hline $\begin{array}{l}\text { F. nucleatum subsp. } \\
\text { animalis 7_1 (Fna) }\end{array}$ & F. nucleatum & Wild Type & [4] \\
\hline DJSVT02 (Fnn) & F. nucleatum & $\begin{array}{l}\text { F. nucleatum } 23726 \Delta \text { galKT } \\
\text { In-frame deletion of galK and galT genes } \\
\text { (Base strain for all target in-frame gene } \\
\text { deletions) }\end{array}$ & This paper \\
\hline DJSVT03 & F. nucleatum & $\begin{array}{l}\text { F. nucleatum } 23726 \Delta \text { galKT fap } 2 \\
\text { In-frame deletion of fap2 in the DJSVT02 } \\
\text { background }\end{array}$ & This paper \\
\hline DJSVT04 & F. nucleatum & $\begin{array}{l}\text { F. nucleatum } 23726 \triangle \text { galKT fadA } \\
\text { In-frame deletion of fadA in the DJSVT02 } \\
\text { background }\end{array}$ & This paper \\
\hline DJSVT05 & F. nucleatum & $\begin{array}{l}\text { F. nucleatum } 23726 \text { ggalKT fap2 fadA } \\
\text { In-frame deletions of fap2 and fadA in the } \\
\text { DJSVT02 background }\end{array}$ & This paper \\
\hline DJSVT06 & F. nucleatum & $\begin{array}{l}\text { F. nucleatum } 23726 \triangle 9 \text { galKT cbpF } \\
\text { In-frame deletion of cbpF in the DJSVTO2 } \\
\text { background }\end{array}$ & This paper \\
\hline DJSVT07 & F. nucleatum & $\begin{array}{l}\text { F. nucleatum } 23726 \triangle \text { galKT fvCB } \\
\text { In-frame deletion of fvCB in the DJSVTO2 } \\
\text { background }\end{array}$ & This paper \\
\hline DJSVT08 & F. nucleatum & $\begin{array}{l}\text { F. nucleatum } 23726 \triangle \text { galKT fvcC } \\
\text { In-frame deletion of fvcC in the DJSVT02 } \\
\text { background }\end{array}$ & This paper \\
\hline DJSVT09 & F. nucleatum & $\begin{array}{l}\text { F. nucleatum } 23726 \triangle g a I K T f V C D \\
\text { In-frame deletion of } f v C D \text { in the DJSVT02 } \\
\text { background }\end{array}$ & This paper \\
\hline DJSVT10 & F. nucleatum & $\begin{array}{l}\text { F. nucleatum } 23726 \triangle g \text { galKT } c b p F f v c B \text { fvcC } \\
\text { fvcD } \\
\text { In-frame quadruple deletion of } c b p F, f v c B \text {, } \\
\text { fvcC, and fvcD in the DJSVTO2 background }\end{array}$ & This paper \\
\hline
\end{tabular}


bioRxiv preprint doi: https://doi.org/10.1101/2020.01.15.907931; this version posted January 16,2020 . The copyright holder for this preprint (which was not certified by peer review) is the author/funder, who has granted bioRxiv a license to display the preprint in perpetuity. It is made available under aCC-BY-NC-ND 4.0 International license.

\begin{tabular}{|c|c|c|c|}
\hline DJSVT11 & F. nucleatum & $\begin{array}{l}\text { F. nucleatum } 23726 \triangle \text { galKT fap2 } c b p F f v c B \\
\text { fvcC fvcD } \\
\text { In-frame quintuple deletion of fap2, } c b p F, f v c B \text {, } \\
\text { fvcC, and fvcD in the DJSVTO2 background }\end{array}$ & This paper \\
\hline DJSVT12 & F. nucleatum & $\begin{array}{l}\text { F. nucleatum } 23726 \Delta \text { galKT arsB::galKT-6xHis } \\
\mathrm{Cm}^{r} \mathrm{Tm}^{r} \\
\text { Complemented strain of } \Delta \text { galKT }\end{array}$ & This paper \\
\hline DJSVT13 & F. nucleatum & $\begin{array}{l}\text { F. nucleatum } 23726 \Delta \text { galKT } \triangle \text { fadA } \\
\text { arsB::fadA-FLAG Cmr } \\
\text { Complemented strain of } \triangle \text { fadA }\end{array}$ & This paper \\
\hline $\begin{array}{l}\text { F. nucleatum subsp. } \\
\text { polymorphum ATCC } \\
10953\end{array}$ & F. nucleatum & $\begin{array}{l}\text { Wild Type } \\
\text { Used to make pan-Fusobacterium antisera in } \\
\text { rabbits. Antisera name: DJSVT_MAS1 }\end{array}$ & ATCC \\
\hline $\begin{array}{l}\text { F. nucleatum subsp. } \\
\text { vincentii ATCC } 49256\end{array}$ & F. nucleatum & $\begin{array}{l}\text { Wild Type } \\
\text { Used to make pan-Fusobacterium antisera in } \\
\text { rabbits. Antisera name: DJSVT_MAS1 }\end{array}$ & ATCC \\
\hline F. periodonticum 2_1_31 & F. periodonticum & $\begin{array}{l}\text { Wild Type } \\
\text { Used to make pan-Fusobacterium antisera in } \\
\text { rabbits. Antisera name: DJSVT_MAS1 }\end{array}$ & [4] \\
\hline F. varium 27725 & F. varium & $\begin{array}{l}\text { Wild Type } \\
\text { Used to make pan-Fusobacterium antisera in } \\
\text { rabbits. Antisera name: DJSVT_MAS1 }\end{array}$ & [4] \\
\hline F. ulcerans 49185 & F. ulcerans & $\begin{array}{l}\text { Wild Type } \\
\text { Used to make pan-Fusobacterium antisera in } \\
\text { rabbits. Antisera name: DJSVT_MAS1 }\end{array}$ & [4] \\
\hline F. mortiferum 9817 & F. mortiferum & $\begin{array}{l}\text { Wild Type } \\
\text { Used to make pan-Fusobacterium antisera in } \\
\text { rabbits. Antisera name: DJSVT_MAS1 }\end{array}$ & [4] \\
\hline F. gonidiaformans 25563 & F. gonidiaformans & $\begin{array}{l}\text { Wild Type } \\
\text { Used to make pan-Fusobacterium antisera in } \\
\text { rabbits. Antisera name: DJSVT_MAS1 }\end{array}$ & [4] \\
\hline $\begin{array}{l}\text { F. necrophorum subsp. } \\
\text { necrophorum } 25286\end{array}$ & F. necrophorum & $\begin{array}{l}\text { Wild Type } \\
\text { Used to make pan-Fusobacterium antisera in } \\
\text { rabbits. Antisera name: DJSVT_MAS1 }\end{array}$ & ATCC \\
\hline $\begin{array}{l}\text { F. necrophorum subsp. } \\
\text { funduliforme 1_1_36S }\end{array}$ & F. necrophorum & $\begin{array}{l}\text { Wild Type } \\
\text { Used to make pan-Fusobacterium antisera in } \\
\text { rabbits. Antisera name: DJSVT_MAS1 }\end{array}$ & [4] \\
\hline $\begin{array}{l}\text { F. nucleatum subsp. } \\
\text { nucleatum ATCC } 25586\end{array}$ & F. nucleatum & $\begin{array}{l}\text { Wild Type } \\
\text { Used in cytokine induction experiments }\end{array}$ & ATCC \\
\hline
\end{tabular}

$\mathrm{Cm}^{r}$, Chloramphenicol resistance

$\mathrm{Tm}^{r}$, Thiamphenicol resistance 
bioRxiv preprint doi: https://doi.org/10.1101/2020.01.15.907931; this version posted January 16, 2020. The copyright holder for this preprint (which was not certified by peer review) is the author/funder, who has granted bioRxiv a license to display the preprint in perpetuity. It is made available under aCC-BY-NC-ND 4.0 International license.

1. Knorr M. Über die fusospirilläre Symbiose, die Gattung Fusobacterium (KB Lehmann) und Spirillum sputigenum. Zugleich ein Beiträg zür Bakteriologie der Mundhohle. II. Mitteilung Die Gattung Fusobacterium I Abt Orig Zentralbl Bakteriol Parasitenkd Infektionskr Hyg. 1922;89: 4-22.

2. Knorr M. Ueber die fusospirilläre symbiose, die Gattung Fusobacterium (KB Lehmann) und Spirillum sputigenum. II Mitteilung. Die Gattung Fusobacterium. Zentbl Bakteriol Parasitenkd Infekt Hyg Abt. 1923;1: 4-22.

3. Dzink JL, Sheenan MT, Socransky SS. Proposal of three subspecies of Fusobacterium nucleatum Knorr 1922: Fusobacterium nucleatum subsp. nucleatum subsp. nov., comb. nov.; Fusobacterium nucleatum subsp. polymorphum subsp. nov., nom. Rev., comb. nov.; and Fusobacterium nucleatum subsp. vincentii subsp. nov., nom. rev., comb. nov. Int J Syst Evol Microbiol. Microbiology Society; 1990;40: 74-78.

4. Manson McGuire A, Cochrane K, Griggs AD, Haas BJ, Abeel T, Zeng Q, et al. Evolution of invasion in a diverse set of Fusobacterium species. MBio. 2014;5: e01864. 
bioRxiv preprint doi: https://doi.org/10.1101/2020.01.15.907931; this version posted January 16,2020 . The copyright holder for this preprint (which was not certified by peer review) is the author/funder, who has granted bioRxiv a license to display the preprint in perpetuity. It is made available under aCC-BY-NC-ND 4.0 International license.

\section{REFERENCES}

1. D. van Elsland, J. Neefjes, Bacterial infections and cancer. EMBO Rep. 19 (2018), doi:10.15252/embr.201846632.

2. A. Gagnaire, B. Nadel, D. Raoult, J. Neefjes, J.-P. Gorvel, Collateral damage: insights into bacterial mechanisms that predispose host cells to cancer. Nat. Rev. Microbiol. 15, 109-128 (2017).

3. H. L. Kaufman, F. J. Kohlhapp, A. Zloza, Oncolytic viruses: a new class of immunotherapy drugs. Nat. Rev. Drug Discov. 14, 642-662 (2015).

4. C. A. Brennan, W. S. Garrett, Fusobacterium nucleatum - symbiont, opportunist and oncobacterium. Nat. Rev. Microbiol. (2018), doi:10.1038/s41579-018-0129-6.

5. Y. W. Han, Fusobacterium nucleatum: a commensal-turned pathogen. Curr. Opin. Microbiol. 23, 141-147 (2015).

6. M. R. Rubinstein, X. Wang, W. Liu, Y. Hao, G. Cai, Y. W. Han, Fusobacterium nucleatum promotes colorectal carcinogenesis by modulating E-cadherin/ $\beta$-catenin signaling via its FadA adhesin. Cell Host Microbe. 14, 195-206 (2013).

7. J. Abed, J. E. M. Emgård, G. Zamir, M. Faroja, G. Almogy, A. Grenov, A. Sol, R. Naor, E. Pikarsky, K. A. Atlan, A. Mellul, S. Chaushu, A. L. Manson, A. M. Earl, N. Ou, C. A. Brennan, W. S. Garrett, G. Bachrach, Fap2 Mediates Fusobacterium nucleatum Colorectal Adenocarcinoma Enrichment by Binding to Tumor-Expressed Gal-GalNAc. Cell Host Microbe. 20, 215-225 (2016).

8. M. Castellarin, R. L. Warren, J. D. Freeman, L. Dreolini, M. Krzywinski, J. Strauss, R. Barnes, P. Watson, E. Allen-Vercoe, R. A. Moore, R. A. Holt, Fusobacterium nucleatum infection is prevalent in human colorectal carcinoma. Genome Res. 22, 299-306 (2012).

9. A. D. Kostic, D. Gevers, C. S. Pedamallu, M. Michaud, F. Duke, A. M. Earl, A. I. Ojesina, J. Jung, A. J. Bass, J. Tabernero, J. Baselga, C. Liu, R. A. Shivdasani, S. Ogino, B. W. Birren, C. Huttenhower, W. S. Garrett, M. Meyerson, Genomic analysis identifies association of Fusobacterium with colorectal carcinoma. Genome Res. 22, 292-298 (2012).

10. S. Bullman, C. S. Pedamallu, E. Sicinska, T. E. Clancy, X. Zhang, D. Cai, D. Neuberg, K. Huang, F. Guevara, T. Nelson, O. Chipashvili, T. Hagan, M. Walker, A. Ramachandran, B. Diosdado, G. Serna, N. Mulet, S. Landolfi, S. Ramon Y Cajal, R. Fasani, A. J. Aguirre, K. Ng, E. Élez, S. Ogino, J. Tabernero, C. S. Fuchs, W. C. Hahn, P. Nuciforo, M. Meyerson, Analysis of Fusobacterium persistence and antibiotic response in colorectal cancer. Science. 358, 1443-1448 (2017).

11. S. Chen, T. Su, Y. Zhang, A. Lee, J. He, Q. Ge, L. Wang, J. Si, W. Zhuo, L. Wang, Fusobacterium nucleatum promotes colorectal cancer metastasis by modulating KRT7-AS/KRT7. Gut Microbes, 1-15 (2020).

12. Y. Chen, Y. Chen, J. Zhang, P. Cao, W. Su, Y. Deng, N. Zhan, X. Fu, Y. Huang, W. Dong, Fusobacterium nucleatum Promotes Metastasis in Colorectal Cancer by Activating Autophagy Signaling via the Upregulation of CARD3 Expression. Theranostics. 10, 323-339 (2020).

13. H. Verbeke, S. Struyf, G. Laureys, J. Van Damme, The expression and role of CXC chemokines in colorectal cancer. Cytokine Growth Factor Rev. 22, 345-358 (2011).

14. C. Zhuo, X. Wu, J. Li, D. Hu, J. Jian, C. Chen, X. Zheng, C. Yang, Chemokine (C-X-C motif) ligand 1 is associated with tumor progression and poor prognosis in patients with colorectal cancer. Biosci. Rep. 38 (2018), doi:10.1042/BSR20180580. 
bioRxiv preprint doi: https://doi.org/10.1101/2020.01.15.907931; this version posted January 16, 2020. The copyright holder for this preprint (which was not certified by peer review) is the author/funder, who has granted bioRxiv a license to display the preprint in perpetuity. It is made available under aCC-BY-NC-ND 4.0 International license.

15. A. Li, M. L. Varney, R. K. Singh, Constitutive expression of growth regulated oncogene (gro) in human colon carcinoma cells with different metastatic potential and its role in regulating their metastatic phenotype. Clin. Exp. Metastasis. 21, 571-579 (2004).

16. A. Li, M. L. Varney, J. Valasek, M. Godfrey, B. J. Dave, R. K. Singh, Autocrine role of interleukin-8 in induction of endothelial cell proliferation, survival, migration and MMP-2 production and angiogenesis. Angiogenesis. 8, 63-71 (2005).

17. H. Ogata, A. Sekikawa, H. Yamagishi, K. Ichikawa, S. Tomita, J. Imura, Y. Ito, M. Fujita, M. Tsubaki, H. Kato, T. Fujimori, H. Fukui, GROa promotes invasion of colorectal cancer cells. Oncol. Rep. 24, 1479-1486 (2010).

18. D. Wang, H. Sun, J. Wei, B. Cen, R. N. DuBois, CXCL1 Is Critical for Premetastatic Niche Formation and Metastasis in Colorectal Cancer. Cancer Res. 77, 3655-3665 (2017).

19. C. Rubie, V. O. Frick, S. Pfeil, M. Wagner, O. Kollmar, B. Kopp, S. Graber, B. M. Rau, M. K. Schilling, Correlation of IL-8 with induction, progression and metastatic potential of colorectal cancer. World J. Gastroenterol. 13, 4996-5002 (2007).

20. L.-C. Chen, C.-Y. Hao, Y. S. Y. Chiu, P. Wong, J. S. Melnick, M. Brotman, J. Moretto, F. Mendes, A. P. Smith, J. L. Bennington, D. Moore, N. M. Lee, Alteration of gene expression in normal-appearing colon mucosa of APC(min) mice and human cancer patients. Cancer Res. 64, 3694-3700 (2004).

21. Y. S. Lee, I. Choi, Y. Ning, N. Y. Kim, V. Khatchadourian, D. Yang, H. K. Chung, D. Choi, M. J. LaBonte, R. D. Ladner, K. C. Nagulapalli Venkata, D. O. Rosenberg, N. A. Petasis, H.-J. Lenz, Y.-K. Hong, Interleukin-8 and its receptor CXCR2 in the tumour microenvironment promote colon cancer growth, progression and metastasis. Br. J. Cancer. 106, 1833-1841 (2012).

22. Q. Liu, A. Li, Y. Tian, J. D. Wu, Y. Liu, T. Li, Y. Chen, X. Han, K. Wu, The CXCL8-CXCR1/2 pathways in cancer. Cytokine Growth Factor Rev. 31, 61-71 (2016).

23. A. Umaña, B. E. Sanders, C. C. Yoo, M. A. Casasanta, B. Udayasuryan, S. S. Verbridge, D. J. Slade, Utilizing Whole Fusobacterium Genomes To Identify, Correct, and Characterize Potential Virulence Protein Families. J. Bacteriol. 201 (2019), doi:10.1128/JB.00273-19.

24. M. Desvaux, A. Khan, S. A. Beatson, A. Scott-Tucker, I. R. Henderson, Protein secretion systems in Fusobacterium nucleatum: genomic identification of Type 4 piliation and complete Type $\mathrm{V}$ pathways brings new insight into mechanisms of pathogenesis. Biochim. Biophys. Acta. 1713, 92-112 (2005).

25. N. Dautin, H. D. Bernstein, Protein secretion in gram-negative bacteria via the autotransporter pathway. Annu. Rev. Microbiol. 61, 89-112 (2007).

26. C. Gur, Y. Ibrahim, B. Isaacson, R. Yamin, J. Abed, M. Gamliel, J. Enk, Y. Bar-On, N. Stanietsky-Kaynan, S. Coppenhagen-Glazer, N. Shussman, G. Almogy, A. Cuapio, E. Hofer, D. Mevorach, A. Tabib, R. Ortenberg, G. Markel, K. Miklić, S. Jonjic, C. A. Brennan, W. S. Garrett, G. Bachrach, O. Mandelboim, Binding of the Fap2 protein of Fusobacterium nucleatum to human inhibitory receptor TIGIT protects tumors from immune cell attack. Immunity. 42, 344-355 (2015).

27. M. L. Brewer, D. Dymock, R. L. Brady, B. B. Singer, M. Virji, D. J. Hill, Fusobacterium spp. target human CEACAM1 via the trimeric autotransporter adhesin CbpF. J. Oral Microbiol. 11, 1565043 (2019).

28. J. Bassler, B. Hernandez Alvarez, M. D. Hartmann, A. N. Lupas, A domain dictionary of trimeric autotransporter adhesins. Int. J. Med. Microbiol. 305, 265-275 (2015).

29. J. Strauss, G. G. Kaplan, P. L. Beck, K. Rioux, R. Panaccione, R. Devinney, T. Lynch, E. Allen-Vercoe, Invasive potential of gut mucosa-derived Fusobacterium nucleatum positively correlates with IBD status of 
bioRxiv preprint doi: https://doi.org/10.1101/2020.01.15.907931; this version posted January $16,2020$. The copyright holder for this preprint (which was not certified by peer review) is the author/funder, who has granted bioRxiv a license to display the preprint in perpetuity. It is made available under aCC-BY-NC-ND 4.0 International license.

the host. Inflamm. Bowel Dis. 17, 1971-1978 (2011).

30. Y. Yang, W. Weng, J. Peng, L. Hong, L. Yang, Y. Toiyama, R. Gao, M. Liu, M. Yin, C. Pan, H. Li, B. Guo, Q. Zhu, Q. Wei, M.-P. Moyer, P. Wang, S. Cai, A. Goel, H. Qin, Y. Ma, Fusobacterium nucleatum Increases Proliferation of Colorectal Cancer Cells and Tumor Development in Mice by Activating Toll-Like Receptor 4 Signaling to Nuclear Factor-k, Up-Regulating Expression of MicroRNA-21. Gastroenterology (2016), doi:10.1053/j.gastro.2016.11.018.

31. M. Xu, M. Yamada, M. Li, H. Liu, S. G. Chen, Y. W. Han, FadA from Fusobacterium nucleatum utilizes both secreted and nonsecreted forms for functional oligomerization for attachment and invasion of host cells. $J$. Biol. Chem. 282, 25000-25009 (2007).

32. U. K. Gursoy, E. Könönen, V.-J. Uitto, Intracellular replication of fusobacteria requires new actin filament formation of epithelial cells. APMIS. 116, 1063-1070 (2008).

33. M. K. H. Schindler, M. S. Schütz, M. C. Mühlenkamp, S. H. M. Rooijakkers, T. Hallström, P. F. Zipfel, I. B. Autenrieth, Yersinia enterocolitica YadA mediates complement evasion by recruitment and inactivation of C3 products. J. Immunol. 189, 4900-4908 (2012).

34. J. Eitel, P. Dersch, The YadA Protein of Yersinia pseudotuberculosis Mediates High-Efficiency Uptake into Human Cells under Environmental Conditions in Which Invasin Is Repressed. Infect. Immun. 70, 4880-4891 (2002).

35. C. Wu, A. A. M. Al Mamun, T. T. Luong, B. Hu, J. Gu, J. H. Lee, M. D’Amore, A. Das, H. Ton-That, Forward Genetic Dissection of Biofilm Development by Fusobacterium nucleatum: Novel Functions of Cell Division Proteins FtsX and EnvC. MBio. 9 (2018), doi:10.1128/mBio.00360-18.

36. H. Nariya, S. Miyata, M. Suzuki, E. Tamai, A. Okabe, Development and application of a method for counterselectable in-frame deletion in Clostridium perfringens. Appl. Environ. Microbiol. 77, 1375-1382 (2011).

37. A. Ikegami, P. Chung, Y. W. Han, Complementation of the fadA mutation in Fusobacterium nucleatum demonstrates that the surface-exposed adhesin promotes cellular invasion and placental colonization. Infect. Immun. 77, 3075-3079 (2009).

38. A. Manson McGuire, K. Cochrane, A. D. Griggs, B. J. Haas, T. Abeel, Q. Zeng, J. B. Nice, H. MacDonald, B. W. Birren, B. W. Berger, E. Allen-Vercoe, A. M. Earl, Evolution of invasion in a diverse set of Fusobacterium species. MBio. 5, e01864 (2014).

39. I. D. Bobanga, F. Allen, N. R. Teich, A. Y. Huang, Chemokines CCL3 and CCL4 Differentially Recruit Lymphocytes in a Murine Model of Early Metastatic Colon Cancer. J. Surg. Res. 186, 515-516 (2014).

40. Y. Itatani, K. Kawada, S. Inamoto, T. Yamamoto, R. Ogawa, M. M. Taketo, Y. Sakai, The Role of Chemokines in Promoting Colorectal Cancer Invasion/Metastasis. Int. J. Mol. Sci. 17 (2016), doi:10.3390/ijms17050643.

41. V. Papayannopoulos, Neutrophil extracellular traps in immunity and disease. Nat. Rev. Immunol. 18, 134-147 (2018).

42. M. Doke, H. Fukamachi, H. Morisaki, T. Arimoto, H. Kataoka, H. Kuwata, Nucleases from Prevotella intermedia can degrade neutrophil extracellular traps. Mol. Oral Microbiol. 32, 288-300 (2017).

43. B. P. Lima, W. Shi, R. Lux, Identification and characterization of a novel Fusobacterium nucleatum adhesin involved in physical interaction and biofilm formation with Streptococcus gordonii. Microbiologyopen. 6 (2017), doi:10.1002/mbo3.444. 
bioRxiv preprint doi: https://doi.org/10.1101/2020.01.15.907931; this version posted January $16,2020$. The copyright holder for this preprint (which was not certified by peer review) is the author/funder, who has granted bioRxiv a license to display the preprint in perpetuity. It is made available under aCC-BY-NC-ND 4.0 International license.

44. C. W. Kaplan, R. Lux, S. K. Haake, W. Shi, The Fusobacterium nucleatum outer membrane protein RadD is an arginine-inhibitable adhesin required for inter-species adherence and the structured architecture of multispecies biofilm. Mol. Microbiol. 71, 35-47 (2009).

45. C. W. Kaplan, X. Ma, A. Paranjpe, A. Jewett, R. Lux, S. Kinder-Haake, W. Shi, Fusobacterium nucleatum Outer Membrane Proteins Fap2 and RadD Induce Cell Death in Human Lymphocytes, , doi:10.1128/IAI.00567-10.

46. Y. Ning, P. C. Manegold, Y. K. Hong, W. Zhang, A. Pohl, G. Lurje, T. Winder, D. Yang, M. J. LaBonte, P. M. Wilson, R. D. Ladner, H.-J. Lenz, Interleukin-8 is associated with proliferation, migration, angiogenesis and chemosensitivity in vitro and in vivo in colon cancer cell line models. Int. J. Cancer. 128, 2038-2049 (2011).

47. E. Cohen-Hillel, I. Yron, T. Meshel, A. Ben-Baruch, Interleukin 8 and cell migration to inflammatory sites: the regulation of focal adhesion kinase under conditions of migratory desensitization. Isr. Med. Assoc. J. 9, 579-583 (2007).

48. P.-L. Kuo, K.-H. Shen, S.-H. Hung, Y.-L. Hsu, CXCL1/GROa increases cell migration and invasion of prostate cancer by decreasing fibulin-1 expression through NF-KB/HDAC1 epigenetic regulation. Carcinogenesis. 33, 2477-2487 (2012).

49. K. Mima, R. Nishihara, Z. R. Qian, Y. Cao, Y. Sukawa, J. A. Nowak, J. Yang, R. Dou, Y. Masugi, M. Song, A. D. Kostic, M. Giannakis, S. Bullman, D. A. Milner, H. Baba, E. L. Giovannucci, L. A. Garraway, G. J. Freeman, G. Dranoff, W. S. Garrett, C. Huttenhower, M. Meyerson, J. A. Meyerhardt, A. T. Chan, C. S. Fuchs, S. Ogino, Fusobacterium nucleatum in colorectal carcinoma tissue and patient prognosis. Gut (2015), doi:10.1136/gutjnl-2015-310101.

50. K. Nosho, Y. Sukawa, Y. Adachi, M. Ito, K. Mitsuhashi, H. Kurihara, S. Kanno, I. Yamamoto, K. Ishigami, H. Igarashi, R. Maruyama, K. Imai, H. Yamamoto, Y. Shinomura, Association of Fusobacterium nucleatum with immunity and molecular alterations in colorectal cancer. World J. Gastroenterol. 22, 557-566 (2016).

51. T. Yu, F. Guo, Y. Yu, T. Sun, D. Ma, J. Han, Y. Qian, I. Kryczek, D. Sun, N. Nagarsheth, Y. Chen, H. Chen, J. Hong, W. Zou, J.-Y. Fang, Fusobacterium nucleatum Promotes Chemoresistance to Colorectal Cancer by Modulating Autophagy. Cell. 170, 548-563.e16 (2017).

52. C. A. Brennan, W. S. Garrett, Gut Microbiota, Inflammation, and Colorectal Cancer. Annu. Rev. Microbiol. 70, 395-411 (2016).

53. A. D. Kostic, E. Chun, L. Robertson, J. N. Glickman, C. A. Gallini, M. Michaud, T. E. Clancy, D. C. Chung, P. Lochhead, G. L. Hold, E. M. El-Omar, D. Brenner, C. S. Fuchs, M. Meyerson, W. S. Garrett, Fusobacterium nucleatum potentiates intestinal tumorigenesis and modulates the tumor-immune microenvironment. Cell Host Microbe. 14, 207-215 (2013).

54. W. S. Garrett, The gut microbiota and colon cancer. Science. 364, 1133-1135 (2019).

55. R. Mizuno, K. Kawada, Y. Itatani, R. Ogawa, Y. Kiyasu, Y. Sakai, The Role of Tumor-Associated Neutrophils in Colorectal Cancer. Int. J. Mol. Sci. 20 (2019), doi:10.3390/ijms20030529.

56. J. Cools-Lartigue, J. Spicer, B. McDonald, S. Gowing, S. Chow, B. Giannias, F. Bourdeau, P. Kubes, L. Ferri, Neutrophil extracellular traps sequester circulating tumor cells and promote metastasis. J. Clin. Invest. (2013), doi:10.1172/JCI67484.

57. J. Park, R. W. Wysocki, Z. Amoozgar, L. Maiorino, M. R. Fein, J. Jorns, A. F. Schott, Y. Kinugasa-Katayama, Y. Lee, N. H. Won, E. S. Nakasone, S. A. Hearn, V. Küttner, J. Qiu, A. S. Almeida, N. Perurena, K. Kessenbrock, M. S. Goldberg, M. Egeblad, Cancer cells induce metastasis-supporting 
bioRxiv preprint doi: https://doi.org/10.1101/2020.01.15.907931; this version posted January 16, 2020. The copyright holder for this preprint (which was not certified by peer review) is the author/funder, who has granted bioRxiv a license to display the preprint in perpetuity. It is made available under aCC-BY-NC-ND 4.0 International license.

neutrophil extracellular DNA traps. Sci. Transl. Med. 8, 361ra138 (2016).

58. K. Mima, Y. Sukawa, R. Nishihara, Z. R. Qian, M. Yamauchi, K. Inamura, S. A. Kim, A. Masuda, J. A. Nowak, K. Nosho, A. D. Kostic, M. Giannakis, H. Watanabe, S. Bullman, D. A. Milner, C. C. Harris, E. Giovannucci, L. A. Garraway, G. J. Freeman, G. Dranoff, A. T. Chan, W. S. Garrett, C. Huttenhower, C. S. Fuchs, S. Ogino, Fusobacterium nucleatum and T Cells in Colorectal Carcinoma. JAMA Oncol. 1, 653-661 (2015).

59. R. Kalluri, The biology and function of fibroblasts in cancer. Nat. Rev. Cancer. 16, 582-598 (2016).

60. Y. Lin, J. Xu, H. Lan, Tumor-associated macrophages in tumor metastasis: biological roles and clinical therapeutic applications. J. Hematol. Oncol. 12, 76 (2019).

61. A. S. Abdulamir, R. R. Hafidh, L. K. Mahdi, T. Al-jeboori, F. Abubaker, Investigation into the controversial association of Streptococcus gallolyticus with colorectal cancer and adenoma. BMC Cancer. 9, 403 (2009).

62. J. H. Abed, J. Emgård, S. Chaushu, W. Garrett, G. Bachrach, Abstract 3300: Gal-GalNAc overexpressed in colorectal carcinoma mediates attachment and colonization of Fusobacterium nucleatum utilizing the Fap2 lectin. Cancer Res. 76, 3300-3300 (2016).

63. C. N. Spaulding, R. D. Klein, S. Ruer, A. L. Kau, H. L. Schreiber, Z. T. Cusumano, K. W. Dodson, J. S. Pinkner, D. H. Fremont, J. W. Janetka, H. Remaut, J. I. Gordon, S. J. Hultgren, Selective depletion of uropathogenic E. coli from the gut by a FimH antagonist. Nature. 546, 528-532 (2017).

64. L. Harbaum, M. J. Pollheimer, P. Kornprat, R. A. Lindtner, A. Schlemmer, P. Rehak, C. Langner, Keratin 7 expression in colorectal cancer--freak of nature or significant finding? Histopathology. 59, 225-234 (2011).

65. B. Huang, J. H. Song, Y. Cheng, J. M. Abraham, S. Ibrahim, Z. Sun, X. Ke, S. J. Meltzer, Long non-coding antisense RNA KRT7-AS is activated in gastric cancers and supports cancer cell progression by increasing KRT7 expression. Oncogene. 35, 4927-4936 (2016).

66. S. M. Singel, K. Batten, C. Cornelius, G. Jia, G. Fasciani, S. L. Barron, W. E. Wright, J. W. Shay, Receptor-interacting protein kinase 2 promotes triple-negative breast cancer cell migration and invasion via activation of nuclear factor-kappaB and c-Jun N-terminal kinase pathways. Breast Cancer Res. 16, R28 (2014).

67. J. Zheng, J. Meng, S. Zhao, R. Singh, W. Song, Campylobacter-induced interleukin-8 secretion in polarized human intestinal epithelial cells requires Campylobacter-secreted cytolethal distending toxinand Toll-like receptor-mediated activation of NF-kappaB. Infect. Immun. 76, 4498-4508 (2008).

68. A. Kuznik, M. Bencina, U. Svajger, M. Jeras, B. Rozman, R. Jerala, Mechanism of endosomal TLR inhibition by antimalarial drugs and imidazoquinolines. J. Immunol. 186, 4794-4804 (2011).

69. W. S. 1. Rasband, ImageJ. Bethesda, MD: US National Institutes of Health. ht tp://rsb. info. nih. gov/ij, 1997-2007 (1997). 